Florida International University

FIU Digital Commons

FIU Electronic Theses and Dissertations

University Graduate School

3-20-2019

\title{
What Factors Influence Affirmative-Action Students' Achievement in Brazilian Federal Universities?
}

Gabriela Martinez Gillespie

Florida International University, gmart017@fiu.edu

Follow this and additional works at: https://digitalcommons.fiu.edu/etd

Part of the Adult and Continuing Education Commons, Higher Education Commons, and the International and Comparative Education Commons

\section{Recommended Citation}

Gillespie, Gabriela Martinez, "What Factors Influence Affirmative-Action Students' Achievement in Brazilian Federal Universities?" (2019). FIU Electronic Theses and Dissertations. 4014.

https://digitalcommons.fiu.edu/etd/4014

This work is brought to you for free and open access by the University Graduate School at FIU Digital Commons. It has been accepted for inclusion in FIU Electronic Theses and Dissertations by an authorized administrator of FIU Digital Commons. For more information, please contact dcc@fiu.edu. 
FLORIDA INTERNATIONAL UNIVERSITY

Miami, Florida

\section{WHAT FACTORS INFLUENCE AFFIRMATIVE-ACTION STUDENTS' ACHIEVEMENT IN BRAZILIAN FEDERAL UNIVERSITIES?}

A dissertation submitted in partial fulfilment of

the requirement for the degree of

DOCTOR OF PHILOSOPHY

in

HIGHER EDUCATION

by

Gabriela M. Gillespie 
To: Dean Michael R. Heithaus

College of Arts, Sciences and Education

This dissertation, written by Gabriela M. Gillespie, and entitled What Factors Influence Affirmative-Action Students' Achievement in Brazilian Federal Universities? having been approved in respect to style and intellectual content, is referred to you for judgment.

We have read this dissertation and recommend that it be approved.

$\begin{array}{r}\hline \text { Eric Dwyer } \\ \hline \text { Norma Goonen } \\ \hline \text { Benjamin Baez, Co-Major Professor } \\ \hline \text { Daniel Saunders, Co-Major Professor }\end{array}$

Date of Defense: March 20, 2019

The dissertation of Gabriela M. Gillespie is approved.

Dean Michael R. Heitahus College of Arts, Sciences and Education

Andrés G. Gil

Vice President for Research and Economic Development And Dean of the University Graduate School

Florida International University, 2019 


\section{ACKNOWLEDGMENTS}

Completing this dissertation would not have been possible without the encouragement, support, and expertise of many individuals. I hesitate to make a list because I may carelessly leave out someone important, and if I did, please forgive me.

Dr. Baez, thank you for your advice, knowledge, and reassurance throughout this process. Your support has been paramount to getting me where I am. You introduced me to Dr. Saunders, who has been a patient, caring, and an invaluable asset to my quantitative woes throughout this process. Thank you, Dr. Saunders. To my other incredible committee members, Dr. Goonen, and Dr. Eric Dwyer: thank you for graciously sharing your time and imparting your knowledge with me.

To say my family has had a role in this accomplishment is an understatement. There were many difficult times in which I contemplated walking away. But during those times, Joe Gillespie, my husband, was always there to remind me why I wanted to do this and to reassure me that I could. His unconditional support and love ensured that I stayed the course. There were many weekends where he would take our beautiful children to play so that I could write.

My children, Julia and Elena, and my nieces, Vanessa, Daniella, Mary Grace, Valentina, and Lia, have also been my inspirations. My parents, Chia and Sergio Martinez, have always been wonderfully resilient and made education a priority in our home. We were often reminded that we would graduate from college - it was not a question of if, but when. I dedicate this degree to them and all of my family. To my siblings, Pri, Fe, and Mari: thank you for supporting me in this long journey. It would be remiss of me to not acknowledge my encouraging in-laws, Amelia and Alton McCoy. 


\begin{abstract}
OF THE DISSERTATION
WHAT FACTORS INFLUENCE AFFIRMATIVE-ACTION STUDENTS'

ACHIEVEMENT IN BRAZILIAN FEDERAL UNIVERSITIES?
\end{abstract}

by

Gabriela M. Gillespie

Florida International University, 2019

Miami, Florida

\title{
Professor Benjamin Baez, Co-Major Professor \\ Professor Daniel Saunders, Co-Major Professor
}

This study aims to determine what personal and family characteristics, pre-college factors, and environmental variables contribute to the affirmative-action student success in Brazilian federal universities, as measured by the final college exam. In 2012, Brazil implemented an aggressive and controversial quota system in federal universities that reserved half of the incoming class spaces for students who graduated from public high schools, followed by prioritization determined by socioeconomic status and race. This study used secondary data collected by the Brazilian Ministry of Education; the population includes 6,557 graduating students from the sampled federal universities majors who took the 2016 ENADE exam (final college exam). Using the IBM statistical package for social sciences (SPSS), Statistics 24, I conducted a hierarchical multiple regressions analysis.

Hierarchical multiple regressions were run to determine if the addition of high school factors, pre-college variables, economic factors, social support variables, and individual involvement variables obtained from a survey improved the prediction of 
ENADE (college exit exam) scores over and above the family and student characteristic variables alone.

The full model included the family income, age, sex, race, father's educational level, mother's educational level, high school location, traditional vs. non-traditional high school, public or private high school, reason for choosing major, university proximity to home, evening student, on-campus living, SES or disability quota type, STEM vs. NonSTEM majors, highly selective university, awarded scholarship, academic involvement scholarship, contribution to family finances, received retention services, working student, institutional and faculty support, received support while facing challenges, general social support to attend college, reading for pleasure, opportunity to learn a foreign language, and number of hours spent studying. It was used to predict the ENADE overall score and was statistically significant, $\mathrm{R}^{2}=0.104, F(3,6529)=50.915, \mathrm{p}<.001$; adjusted $\mathrm{R}^{2}=$ 0.10 .

This study adds to prior research by extending the U.S-based student development theory, specifically Astin's theory of student involvement, to a new population: Brazilian university students. It also focuses on the academic achievements of quota-students only, legitimatizing a space in higher education where they have been habitually excluded and marginalized. Quota-students are primarily analyzed in the context of measuring up to the academic level of non-quota students. 


\section{TABLE OF CONTENTS}

CHAPTER

PAGE

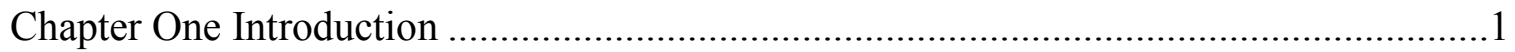

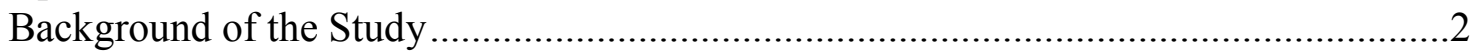

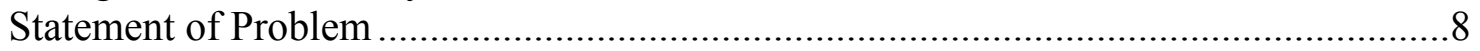

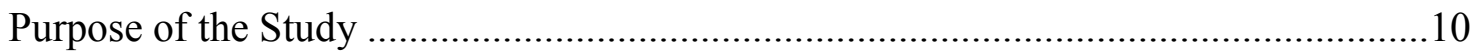

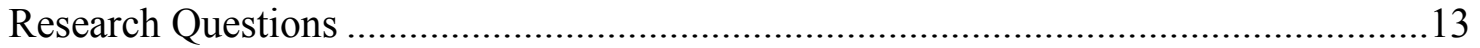

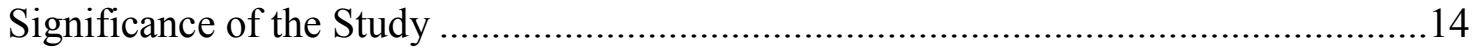

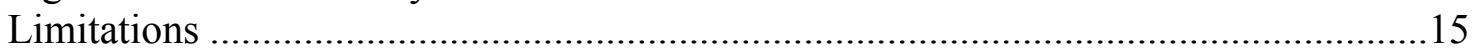

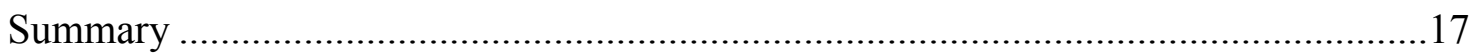

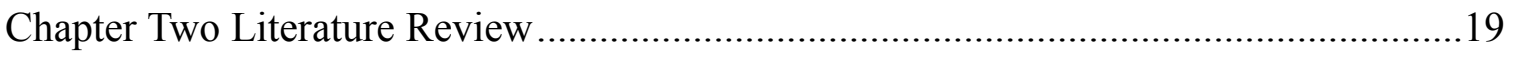

Affirmative-Action Approaches in the U.S. and Brazil ..........................................20

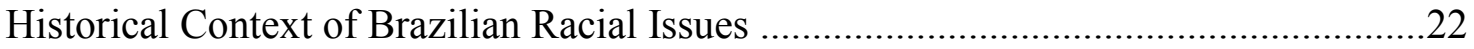

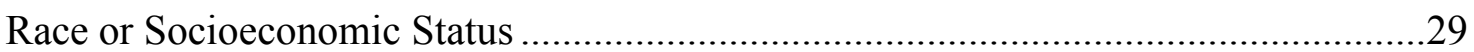

The Trajectory of Underrepresented (Low Socioeconomic Students) in Higher

Education Before Implementation of Affirmative-Action .............................................38

Academic Performance of Affirmative-action Students ..............................................40

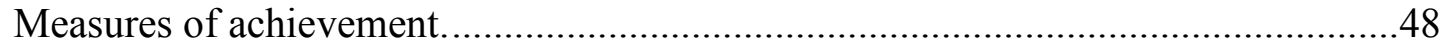

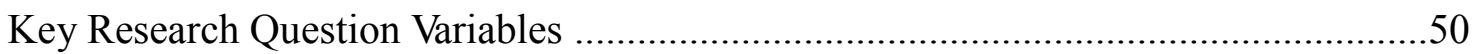

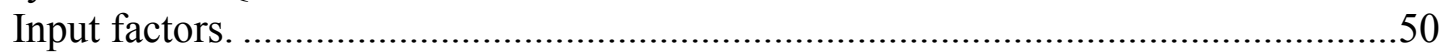

Environmental variables ..............................................................................53

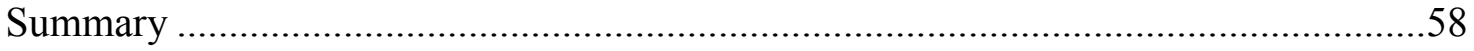

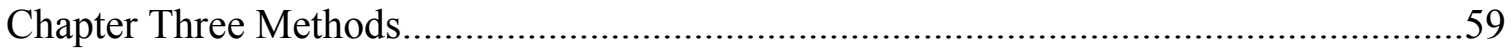

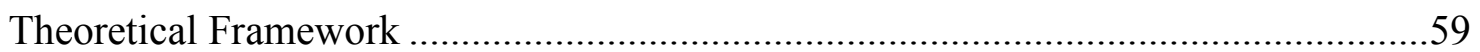

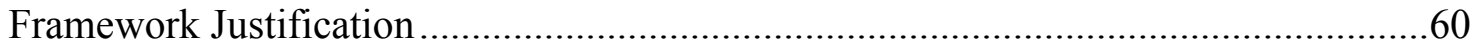

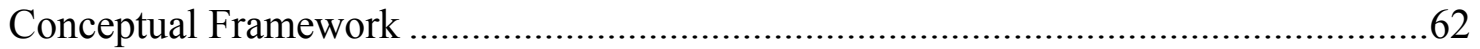

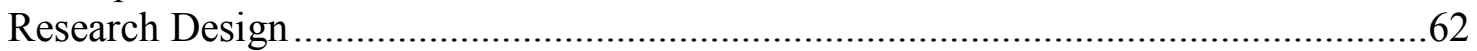

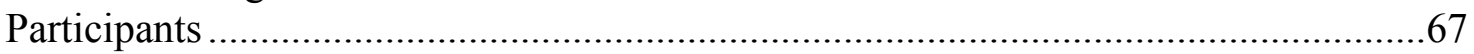

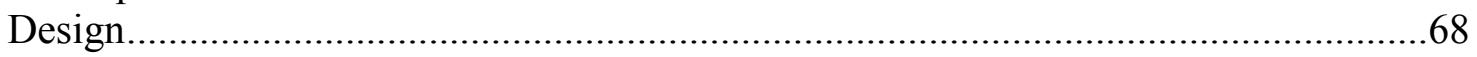

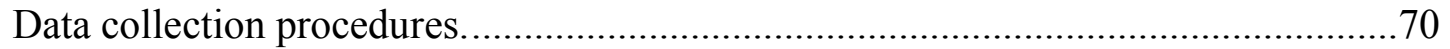

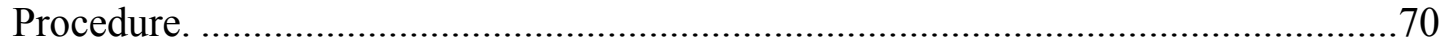

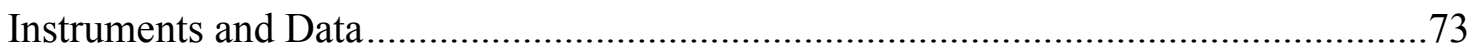

Independent variables: Input blocks 1-2: Characteristics and high school variables. 74

Independent variables: Environment block 3: Pre-college variables...........................76

Independent variables: Environment block 4: Economic factors. ................................79

Independent variables: Environment block 5: Social, institutional, and faculty

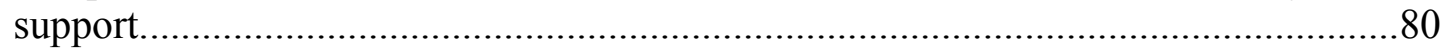

Independent variables: Environment block 6: Individual involvement. ......................81

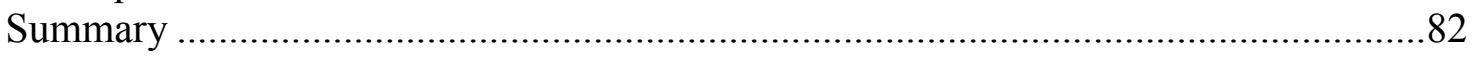




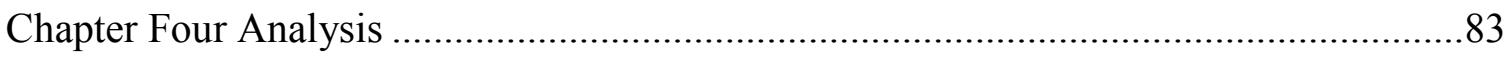

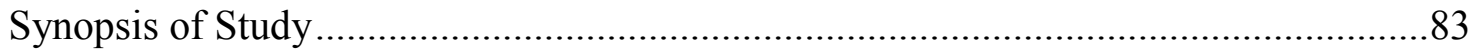

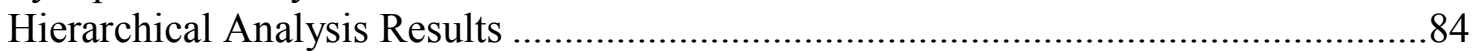

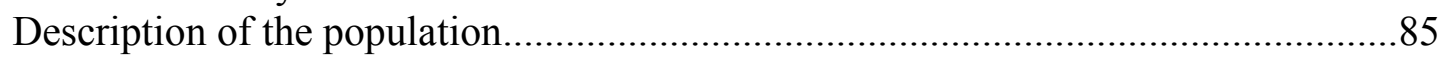

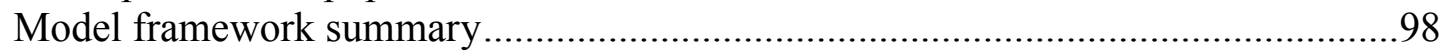

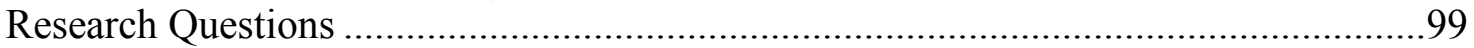

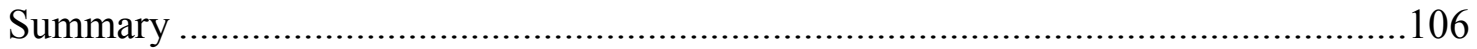

Chapter Five Conclusions Implications and Recommendations ....................................108

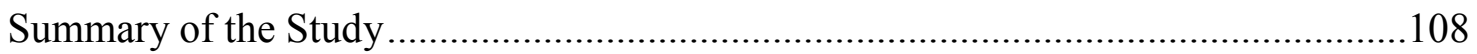

Discussion of the Findings .................................................................................110

Input variables, personal, and family characteristics variables, Block 1 ..................112

Input variables, high school factors, block 2 ......................................................116

Bridge block, pre-college variables, Block 3 .........................................................117

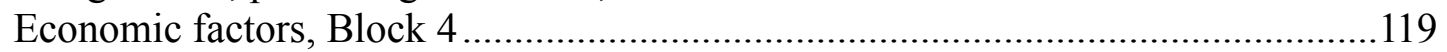

Social, institutional, and faculty support variables, Block 5...................................121

Individual involvement variables, Block 6 .....................................................122

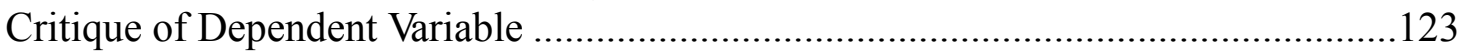

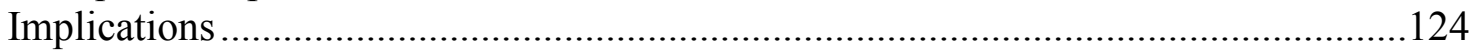

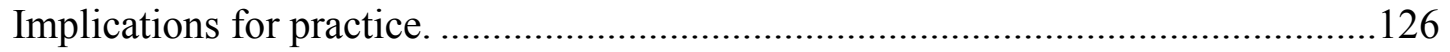

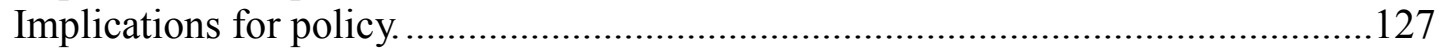

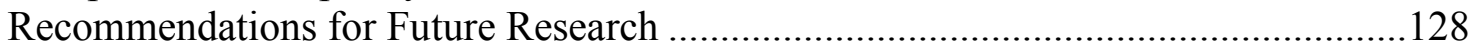

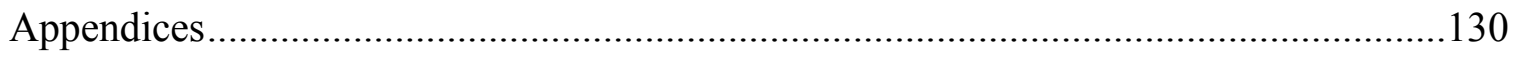

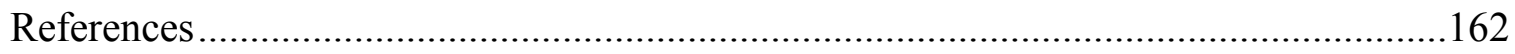

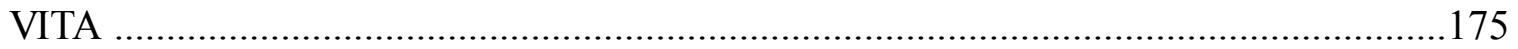




\section{LIST OF TABLES}

TABLE

PAGE

Table 1. Educational Distribution By Race or Color and Level of Instruction, Brazil 2014...

Table 2. Key Events in Brazilian History.................................................................28

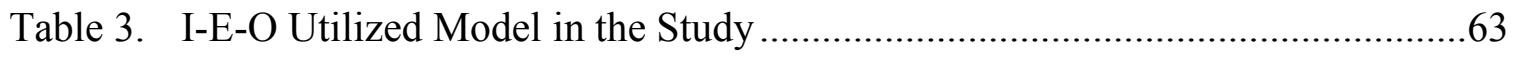

Table 4. Dependent Variable .......................................................................................66

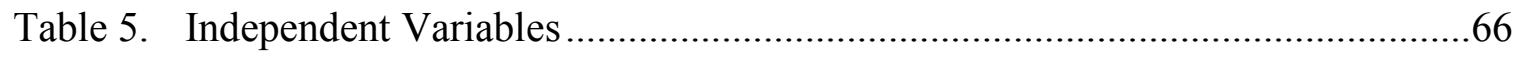

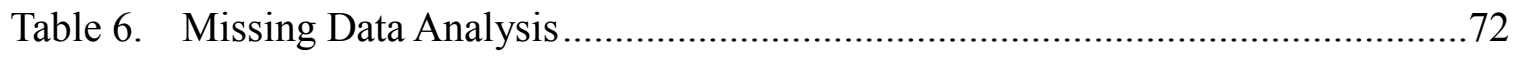

Table 7. Course Evaluation Index Breakdown for Federal Universities 2016..............79

Table 8. Frequency Distributions: Personal Characteristics and Family

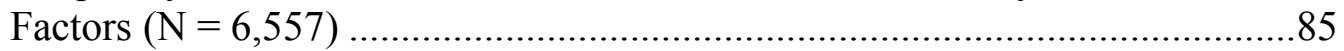

Table 9. Frequency Distributions: High School Variables $(\mathrm{N}=6,557)$......................... 88

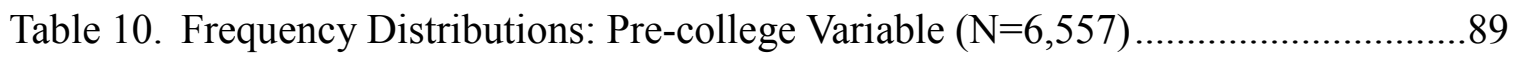

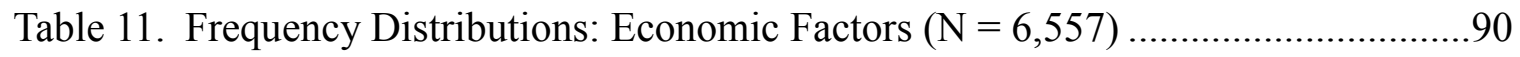

Table 12. Frequency Distributions: Social, Institutional, and Faculty

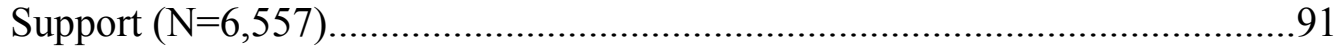

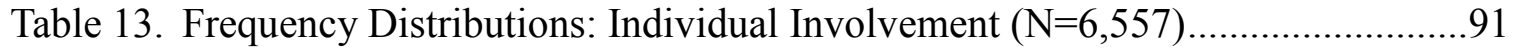

Table 14. Hierarchical Multiple Regression Predicting ENADE Scores ........................93

Table 15. Summary of the Findings by Research Question .......................................102 


\section{LIST OF FIGURES}

FIGURE

PAGE

Figure 1. Law of Social Quotas for Federal University Admission Distribution ...............7

Figure 2. Astin's Input-Environment-Outcomes (I-E-O) Model (1993). .........................61 


\section{Chapter One \\ Introduction}

When asked if he had ever experienced racism on or off the soccer field, Neymar shocked the world by responding, "It's not like I am black, you know?” (de Oliveira, 2018, para. 3). Brazilians have an obfuscated relationship with race and racism. During carnival and events such as the world cup, the world sees Black and White Brazilians coexisting, dancing, and playing soccer. The reality of life, prospects for employment, and higher education degree attainment are striking, as Black and Brown Brazilians are significantly disadvantaged as compared to Whites. ${ }^{1}$ The following chapter will highlight some historical factors that may explain why Neymar believes he is not Black and why some think there is no racism in Brazil. This dissertation focuses on the quota-system in the federal universities in Brazil and identifies the factors that contribute to the quotastudent academic success. ${ }^{2}$ Briefly, the 2008 Law of Social Quotas mandates that all federal universities use a quota system by reserving half of the incoming class admission spaces to students who attended secondary public schools, prioritizing Black and Brown students.

\footnotetext{
${ }^{1}$ The IBGE [Brazilian Institute of Statistics and Geography] classification for race is broken down among White, Black, Brown (pardo), yellow (Asian), and indigenous people. Unlike the scenario in the U.S., which will be discussed later, race classification in Brazil is more fluid and complex. For the data in this study, the term Black, unless otherwise noted, encompasses both Brown and Black individuals. Note that Brown is not considered a pejorative term in Brazil. This study is not intended to address the acceptability of Brazil's racial classification system.

${ }^{2}$ The term "quota-student" is widely used in Brazilian research articles and is not considered a pejorative term. The term "quota" is generally not well-perceived in the U.S., but in Brazil, the term is derived from the language used in national affirmative action law. While this may be shocking to a U.S. audience, the term quota-admitted will be used for the remainder of the document as that is the language used in Brazil. It is not meant pejoratively.
} 
Chapter One presents an overview of the study, background, statement of the problem, the significance of the study, conceptual framework, research questions, limitations, and summary. This study aims to examine the impact of student and family characteristics and environmental factors (e.g., college involvement and support systems) on the academic performance of quota-admitted students in Brazilian federal universities.

\section{Background of the Study}

Brazil has the highest concentration of Afro-descendant people outside of Africa (Darby, 2010). According to the Instituto Brasileiro de Geografia e Estatística [Brazilian Institute of Statistics and Geography] ("IBGE"), in 2014, a little more than half (53.6\%) of the people in Brazil were either Black or Brown, in contrast to 2004, when the census revealed that $51.2 \%$ of the population self-classified as White (Instituto Brasileiro de Geografia e Estatística, 2015). Table 1 illustrates the educational level of Brazilians by race as of $2014 .{ }^{3}$ Seventy-one percent of all individuals who completed higher education were White, while only $29 \%$ of higher degree holders were Black or Brown Brazilians. Additionally, while $17 \%$ of all Brazilians surveyed had completed higher education, there was a significant disparity between the racial makeup of these degree holders. A quarter of all Whites had completed their higher education when compared to a mere $11 \%$ of Black or Brown Brazilians. Conversely, of those who did not finish any schooling, 70.6\% were Black or Brown when compared to the $29.4 \%$ of Whites.

\footnotetext{
${ }^{3}$ This table excludes yellow (Asian) and indigenous races.
} 
Table 1. Educational Distribution By Race or Color and Level of Instruction, Brazil 2014 Educational Level Distribution of level of instruction, by

Distribution of race or race color by the level of instruction

$\begin{array}{lrrrrrrr} & \text { Total } & \text { White } & \text { Black }^{\mathrm{a}} & \text { Difference } & \text { Total } & \text { White } & \text { Black }^{\mathrm{a}} \\ \text { No schooling } & 7.7 \% & 4.4 \% & 11.2 \% & (-) 6.8 \% & 100 \% & 29.4 \% & 70.6 \% \\ \text { Incomplete Basic } & 26.1 \% & 22.3 \% & 30.6 \% & (-) 8.3 \% & 100 \% & 43.5 \% & 56.5 \% \\ \text { Basic completed } & 13.6 \% & 12.7 \% & 14.9 \% & (-) 2.2 \% & 100 \% & 47.3 \% & 52.7 \% \\ \text { Intermediate }^{\mathrm{c}} & 34.1 \% & 36.0 \% & 32.7 \% & 3.3 \% & 100 \% & 53.7 \% & 46.3 \% \\ \text { completed } & & & & & & & \\ \text { Higher Education }^{\mathrm{d}} & 17.6 \% & 24.6 \% & 10.6 \% & 14.0 \% & 100 \% & 71.0 \% & 29.0 \%\end{array}$

Notes. Adapted from "Síntese de indicadores sociais: uma análise das condições de vida da população brasileira [Synthesis of social indicators: An analysis of the living conditions of the Brazilian population]" by the Instituto Brasileiro de Geografia e Estatística [IBGE], p. 100, 2017.

a The Black category is inclusive of Brown individuals.

b Basic education level is compulsory schooling from age 6 to age 14, most closely aligned with Elementary and Middle School years in the U.S.

c Intermediate (Medio) is comprised of three years of study, completed after the basic education and before Higher Education. It is equivalent to High School in the U.S.

d Higher Education includes technical, undergraduate, and graduate degrees.

In 1997, Fernando Henrique Cardoso became the first head of state in Brazil to publicly acknowledge racial inequality and the existence of racism (S. A. Dos Santos, 2014). Efforts to enact affirmative-action policies within the government preceded the enactment of the 2008 Law of Social Quotas, the law that directly targeted higher education admissions and which is the subject of this study. Cardoso, who was the President of Brazil from 1995 to 2003, introduced a national affirmative-action program to increase the participation of Black and Brown Brazilians in public office through race- 
based quotas (S. A. Dos Santos, 2014; Htun, 2004). These programs, however, were not successfully implemented (Dos Santos, 2014).

In 2001, a state university in Rio de Janeiro implemented the first affirmativeaction policy for higher education in the nation. Brazil's racial democracy myth is one factor that contributed to the delay, as the mythical narrative claims that Brazil experiences little racism and that, therefore, there is no need for such a policy (Darby, 2010; Guimarães, 2003). The myth also maintains that Blacks and Browns are more impoverished than Whites because of their social and economic status and not racial discrimination, since Brazil did not have legal segregation like in other countries, such as the United States (Htun, 2004; Menin, Shimizu, Da Silva, Cioldi, \& Buschini, 2008). It was the Brazilian sociologist Gilberto Freyre who first described the myth from the book Casa-grande \& Senalza (in English, The Masters, and the Slaves) in 1933. In challenging the racial democracy myth, Deba and Guimarães (2003) underscored that though Brazil spent $20 \%$ of its GDP on social programs and had a per capita income of US $\$ 2,900$ in 2000 , poverty persisted. They concluded that this poverty must be a result of "large income inequalities and inefficient public spending" (as cited in Brasil, 2000, p. 255). Furthermore, the lack of a rigid racial classification system used by the government to avoid creating and accepting the existence of racial disparity in education and the socioeconomic status of Whites and Browns/Blacks contributed to the delay in the creation of such policies (Htun, 2004). 
Black political mobilization, which started in the 1970s, grew significantly after the transition to democracy in $1985 .{ }^{4}$ The U.S. civil rights movement also influenced the mobilization in Brazil. Htun (2004) explains that a series of reports detailing the racial inequalities in Brazil was a turning point in the recognition of racial disparities in Brazil. Cardoso, who was the president then, was actively recruiting and promoting Black candidates to run in local elections. At the same time, in preparation for the World Conference on Racism in Durban, South Africa, in September 2001, the chair of the committee held meetings and included many constituents, including NGOs and university lecturers, to gather information on Brazil's position on the topic. A racism conference in Rio in July 2001 was a result of these discussions and preparations. The committee for the Durban conference released a report supporting quotas and other forms of affirmative-action to combat racial inequalities (Htun, 2004). The conference's final recommendations echoed these findings (Htun, 2004).

In the same year, in the state of Rio de Janeiro, two state higher education institutions implemented race-based affirmative-action plans that reserved $40 \%$ of their new incoming class for self-declared Blacks and Browns (Tavolaro, 2008). In 2004, the Federal University of Bahia implemented a voluntary affirmative-action policy to better serve its citizens (Cerqueira Lima \& Pereira de Anunciacao, 2008). About three-quarters of the population of Bahia is considered Afro-descendant ("Census - População residente, por cor ou raça, segundo a situação do domicílio, o sexo e a idade [ Census - Resident population, by color or race, according to household status, sex and age]," 2010)

\footnotetext{
${ }^{4}$ From 1964-1985, Brazil was under the control of a military dictatorship.
} 
Finally, in 2008, the federal government proposed a law, known as the Law of Social Quotas, to bring together a more extensive national affirmative-action policy in public higher education. ${ }^{5}$ The law mandates that all federal universities use a quota system by reserving half of the incoming class admissions spaces to students who attended secondary public schools, prioritizing Black, Brown, and indigenous students as secondary criteria based on the state's racial demographics and considering their incomes. Figure 1 illustrates the Law of Social Quotas distribution in percentages and conditions. The law was challenged and litigation continued until August 2012, when Brazil's Supreme Court ruled that the law was constitutional.

In the private sector, some changes were made to encourage increased access to admission for Blacks, Browns, and other underrepresented populations. In 2005, the federal government created O Programa Universidade para Todos [A Program for University for All], more commonly known as "PROUNI." The new law provided an opportunity for students to earn government-funded scholarships to attend private universities. PROUNI also gave the Ministry of Education access to monitor private universities, which had historically been largely overlooked (D. A. R. Dos Santos, Amoedo da Costa, \& Da Silva Faceira, 2015)

\footnotetext{
${ }^{5}$ Law No 12.711 (Brazil, 2012)
} 


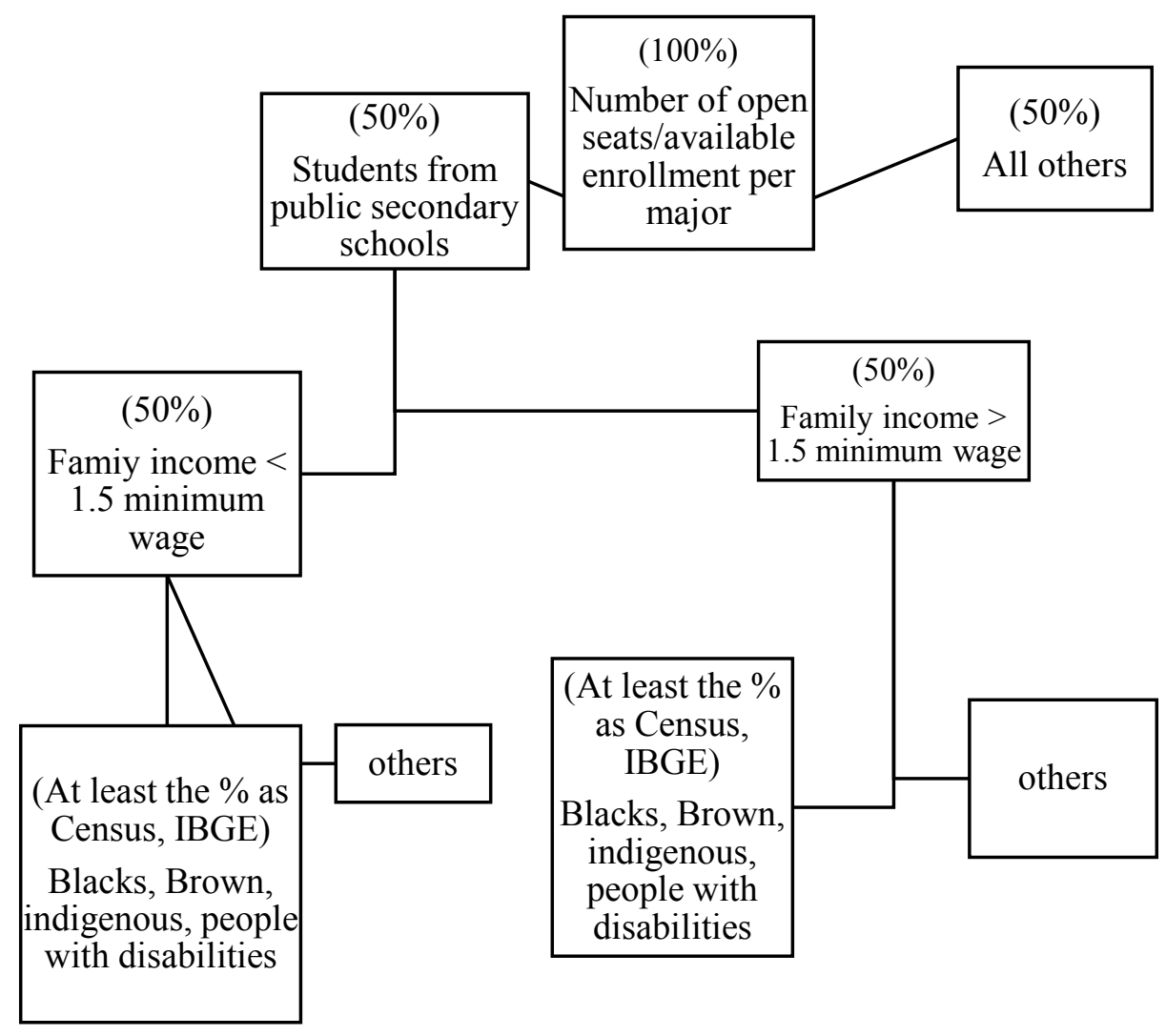

Figure 1. Law of Social Quotas for Federal University Admission Distribution Note: Adapted from "Entenda as cotas para quem estudou todo o ensino medio em escola publicas [Understand quotas for those who studied in public high schools]", MEC [Brazil Ministry of Education], 2012.

Students wishing to apply for this program must (1) have graduated from a public high school, attended a private high school on a full scholarship, or have a disability; (2) take the ENEM (Exame Nacional do Ensino Medio [National High School Exam]), an exam used for college entrance administered by the government; and (3) meet the program's family income limits. To earn the full tuition scholarship, a student's familial 
income cannot exceed 1.5 times the minimum wage, and to receive $50 \%$ tuition, the student's familial income cannot exceed 3 times the minimum wage (Ministério da Educação - Brasil [Brazil Ministry of Education], 2018). The private higher-education sector, however, is not within the scope of the dissertation as the Law of Social Quotas does not extend to private universities.

In 2007, the government took on a new project to restructure and expand the federal universities, called REUNI (Reestruturacao e Expansao das Universidades Federais [Restructure and Expansion of Federal Universities]). The main objectives were to increase public access to higher education by increasing the enrollment opportunities in the evening course instruction, to restructure university curriculum by focusing on social-inclusion efforts and retention programs, and to improve the transferability of students from school to school (Ministério da Educação - Brasil [Brazil Ministry of Education], 2007). The initiative led to the creation of offices on federal university campuses that are designed to help students who qualify for housing, childcare, and food stipends or subsidies. Tutoring services are also offered.

Brazil invested in the REUNI and PROUNI programs among other goals to reduce the inequality in Brazilian institutions of higher education before the enactment of the Law of Social Quotas in 2008. Many proponents and opponents of race-based quotas have been looking for evidence of its successes or failures.

\section{Statement of Problem}

Brazil is a mixed-race country, one with the largest Afro-descendant population outside of African countries (Darby, 2010). Yet the Brown or Black citizens are severely lagging in higher-education completion rates. More specifically, $25 \%$ of Whites complete 
tertiary education when compared to the mere $11 \%$ of Black or Browns (Instituto Brasileiro de Geografia e Estatística, 2017). Consistently documented and theorized, it was found that this achievement gap exists primarily as a result of Brazil's history of miscegenation, the racial democracy myth, and a lack of policies to mitigate the gap. In 2008, however, the actors in the Brazilian government, influenced by local activists and international pressure, instituted a national affirmative-action plan in higher education, known as the Law of Social Quotas (Htun, 2004). As shown in Figure 1, the law specifies that $50 \%$ of spaces must be reserved for affirmative-action applicants, and of those spaces, half must be reserved for students with family income less than 1.5 times the minimum wage, while also taking into consideration the racial makeup of the state.

Before this law came into place, many state and municipal universities chose to implement voluntary quota programs with varying requirements. Most included some combination of race and public secondary school attendance as conditions for admission. Since then, researchers have studied the Law of Social Quotas through one of two lenses. The first lens focused on the racial versus socioeconomic requirements of the law while the second compared the academic achievement of quota and non-quota admits. However, there is a paucity of studies related to the influence of environmental variables on the academic performance of students admitted under the affirmative-action program.

While some research supports that quota-admits can achieve similar academic success when compared to their peers (Cardoso, 2008; Childs \& Stromquist, 2015; Ribeiro, 2016; Valente \& Berry, 2017; Velloso, 2009; Ribeiro, 2016), few studies have compared the academic achievement of students in the aggregate (Valente \& Berry, 2017; Waltenberg \& Carvalho, 2013). Others have focused on institutional effects (Francis \& 
Tannuri-Pianto, 2012b; Pedrosa, Dachs, Maia, Andrade, \& Carvalho, 2007) or the impact of the law on a particular level of students, such as law students (Ribeiro, 2016). Current studies have considered some student characteristics (e.g., race, socioeconomic status, type of high school attended), but none have examined the role of environmental factors, namely university programs and support services, and their influence on quota-admitted student academic performance.

\section{Purpose of the Study}

The main aim of this study is to examine the effects of student and family characteristics, social support, student involvement, and economic factors on the academic attainment of quota-admitted students in Brazilian federal universities. Drawing from the theoretical framework of Astin's theory of student involvement (1984) and the social support theory (Malecki \& Demaray, 2006; Tardy, 1985), the current study uses hierarchical multiple regression to control for input variables (e.g., socioeconomic status, race, gender, age, parental educational achievement) in order to measure the impact of environmental factors (e.g., high school factors, faculty and institutional support, individual student involvement) on the final college examination.

Alexander Astin's (1984) theory of student involvement emphasizes the extent to which the amount and quality of engagement affect college students' development. (Evans, Forney, Guido, Patton, \& Renn, 2010). The degree to which students develop (learn) while in college is proportional to the quality and amount of time they are engaged in activities in college (the environment) (Evans et al., 2010). 
Astin's theory has five fundamental components (Evans et al., 2010, p. 31):

1. Involvement refers to the investment of physical and psychological energy in various objects;

2. Regardless of the object, involvement occurs in a continuum;

3. Involvement has both quantitative and qualitative features;

4. The amount of student learning and personal development associated with any educational program is directly proportional to the quality and quantity of student involvement in the program; and

5. The effectiveness of any educational policy or practice is directly related to the capacity of that policy to increase student involvement.

In this dissertation, Astin's theory of student involvement is used to inform the selection of the environmental variables, such as time spent studying, involvement on campus, evening vs. day student, opportunity to learn a foreign language, number of books read, working status, etc. These variables were also identified through a broader literature review.

In addition to Astin's theory of student involvement, the present study draws from social support theory. Social support is defined by Malecki and Demaray (2006) as “one's perception of supportive behaviors from individuals in his or her social network that enhances functioning and/or may buffer him or her from adverse outcomes” (p. 377). Previous studies have shown a positive relationship between perceived social support and academic achievement (reviewed in Chapter Two). To a lesser extent, this study also references the work of Tinto (1975), which states that students who become socially engaged on campus are less likely to leave the institution than those who are withdrawn 
and not involvement on-campus, and as a result, socially engaged students graduate at a higher rate. Students' social and academic integration while in college will in turn "increase [their] commitment to their goals as well as towards the institution" (Harper, S. R.; Quaye, 2009, p. 273.).

Similar to Astin's theory of student involvement, Tinto's theory emphasizes campus engagement and integration as key factors for retaining students. This study evaluates quota-admitted students' engagement and involvement on campus and determines if an association between involvement and student academic achievement is seen in students in federal universities in Brazil. Referring back to the social support theory, three variables in this dissertation aim to capture a student's social support network and determine if there is a relationship between quota-admitted students who receive social support and the measured outcome, the final college exam.

In this study, the dependent variable is the final college examination, which is measured by the Exame Nacional do Desempenho de Estudantes (ENADE [National Exam for the Assessment of Student Performance]). ${ }^{6}$ The exam is required by all graduating students who are majoring in the particular majors evaluated by the Ministry of Education in any given year. The exam is compulsory for all students in the selected majors in all Brazilian institutions of higher education.

In reviewing the literature for quota-admitted students in Brazilian universities, it was understood that previous studies have looked at some student characteristics - such as race, socioeconomic status, the type of high school attended - but none have examined

\footnotetext{
${ }^{6}$ Unless otherwise noted, all translations in this document were done by the author.
} 
the role of environmental factors and their influence on affirmative-action student academic performance. The goal of the Law of Social Quotas was intended to increase equity for Brown and Black students, who have historically not been adequately represented in the higher education domain. To effectively achieve this goal, university administrators, faculty members, and government officials need to know what factors influence students' success. ${ }^{7}$

\section{Research Questions}

The broad research question guiding the study is: What factors influence affirmativeaction students' achievement in Brazilian federal universities? This question is operationalized in terms of the statistical analysis used to answer it. In other words, what is the overall explanatory power of the full model? The larger research question is parceled out into six sub-questions, which are aligned with specific blocked variables guided by the literature review. The primary question guiding the study is: What is the overall explanatory power of the full model? In other words, after including all the variables (i.e., the characteristics and family demographics, high school variables, precollege variables, economic variables, social support variables, and individual involvement variables), how well does the model explain the performance of quotaadmitted students' performance in the ENADE exam?

\footnotetext{
${ }^{7}$ Not within the scope of this study is the attrition rate of higher education students in Brazil in general, which are speculated to be very high (Schwartzman \& Paiva, 2016). One would suspect that this number might be higher for underrepresented students, though Cardoso (2008) and Bezzera (2011) found that quota-students had lower attrition rates than non-quota students.
} 
The sub-research questions are as follows:

1. What influence do entering student characteristics and family demographics have on the performance of the overall ENADE score of quota-admitted students?

2. What influence do high school variables have on the performance of quotaadmitted students in the overall ENADE score?

3. What influence do pre-college variables have on the performance of quotaadmitted students in the overall ENADE score?

4. What influence do economic variables (after controlling for the above variables) have on performance of quota-admitted students in the overall ENADE score?

5. What influence do social support variables, inclusive of institutional and faculty support (after controlling for the above variables), have on the performance of quota-admitted students in the overall ENADE score?

6. What influence do individual involvement variables (after controlling for the above variables) have on the performance of quota-admitted students in the overall ENADE score?

\section{Significance of the Study}

Controversies over affirmative-action programs do not seem to end. The findings of this study will benefit the society by providing information on the factors that contribute to the success of affirmative-action students in Brazil. By understanding these factors, faculty members, university administrators, and students can provide appropriate resources and take actions to impact the success of these underrepresented majority students. Government and university administrators will be better equipped to make financial, policy, and practical decisions about resources based on evidence. 
Additionally, by focusing solely on underrepresented students, the study seeks to legitimize these students' place in higher education. Previous studies have focused on a comparative approach, putting quota and non-quota students' side-by-side with an underlining tone that the goal of quota students should be to reach the academic achievement levels of non-quota students. This study aims to divorce the antagonistic contrast and bring value to a quota-only study to understand the quota student independently of other students.

Lastly, this study aims to extend the use of student development theory to understand and explain student academic success to a new population, Brazilian university students. Student development theory has been widely used in the U.S. college student population for decades.

\section{Limitations}

There are three limitations to this study that should be highlighted. First, this study does not measure student retention. This study does not look at the differences in the environmental impact on students who did and did not obtain a bachelor's degree. Instead, the study focuses exclusively on students who have obtained their bachelor's degrees and examines the impact of environmental variables, student characteristics, and outcome variables on the ENADE exam.

Second, this study does not have a direct measure of high school grades. A significant predictor of college success is prior success in high school. Astin (1993) emphasizes the need to control for previous academic achievement before measuring the impact of the environment in outcomes. High school grades and college entrance exams in the U.S. are two of the strongest predictors of college grades (Astin, 1993). In Brazil, 
high school grades are not part of the college admissions process. In the present study, a proxy for previous academic achievement is the type of high school (public vs. private), types of courses received in high school (traditional vs. non-traditional), and whether an academic scholarship was used to fund higher education.

In Brazil, researchers have compared the entrance exam scores and academic performances of quota and non-quota students and found weak relationships between the entrance exam and the academic performance of quota-admitted students (Bezzera, 2010; Cardoso, 2008; Childs \& Stromquist, 2015). In other words, quota students tended to score lower on the entrance exams when compared to non-quota students. But in the studies conducted by Bezzera (2010), Childs and Stromquist (2015), and Cardoso (2008), on average, the quota students' performance was close to that of non-quota students after enrollment, except in science disciplines. Particularly interesting is that Bezzera (2010) found that the dropout rate of quota students was half the dropout rate of non-quota students. Additionally, universities in Brazil do not use high school grades in the admissions process. Instead, students are admitted on the basis of their scores on either the Exame Nacional do Ensino Médio (ENEM [National High School Examination]) or the university-specific vestibular examinations (Ministerio de Educacao [Ministry of Education], 2018). ${ }^{8}$ Created in 1998, ENEM's objective is to assess student learning during K-12 education (Ministerio de Educacao [Ministry of Education], 2018).

\footnotetext{
${ }^{8}$ Vestibular is a university specific exam used for college admission by major. The top scoring individuals are selected to the university, and no other criteria are used for admission.
} 
Lastly, a potential limitation is the socioeconomic survey's reliability and validity. The ENADE exam, along with a socioeconomic questionnaire, was developed and administered by the Brazilian Ministry of Education in some variation since 2004. To date, ENADE is still the best measure of student success that can be evaluated across universities as it is the only exam administered to all students regardless of university or major. For this study, there are no alternatives given the scope of the research questions. The socioeconomic questionnaire is administered before the exam and is self-reported. The ministry of education does not release information on this survey's reliability or validity. ${ }^{9}$ The researcher constructed grouped variables based on previous research studies using a principal component analysis and Cronbach alpha to measure internal consistency for specific variables, which is a measure of instrument reliability. Chapter Three will provide detailed information about these limitations.

\section{Summary}

Brazil is a mixed-raced nation with a little more than $50 \%$ of its population selfreporting as Black or Browns individuals (Darby, 2010). Yet, there is a significant gap in the tertiary completion rates between Whites and Black or Brown individuals. Since the implementation of the Law of Social Quotas in 2012 (passed in 2008), researchers have focused on the academic achievement of quota-students as compared to their non-quota counterparts. A literature review revealed relative success on the part of quota students despite predictions that quota students would not succeed in federal universities. This

\footnotetext{
${ }^{9}$ For more information critiquing ENADE exam, see Predrosa, Amaral, \& Knobel, 2013.
} 
study aims to understand the factors that contribute to quota-student academic success in the federal universities in Brazil.

Chapter Two will explain how historical factors such as miscegenation of races, late abolishment of slavery, lack of race consciousness among other factors that contribute to educational attainment inequity. The federal government enacted a law to mitigate this inequity, known as the Law of Social Quotas. The next chapter also evaluates the current studies investigating the Law of Social Quotas. 


\section{Chapter Two \\ Literature Review}

A set of twins applied for admission at the University of Brasilia (UnB) after the implementation of a race-based affirmative-action program at the university. Through a review of photographs, a panel of judges determined that one was Black and admitted that twin, while the other twin was identified as White and denied entry ("Para UNB, um era branco e outro, negro [To UnB one was White and the other Black]," 2012). This is another example of the challenge and complexity of race-based policies and politics in Brazil. UnB reversed its ruling once the facts emerged, but the problem still remains: Who is Black? This chapter will provide some historical context as well as a literature review of current and previous studies on quota students in higher education before and after the implementation of the Law of Social Quotas.

The literature review is organized into six sections. The first section includes an abridged comparative analysis of U.S. and Brazilian higher education affirmative-action approaches. Part two covers the historical aspects that led to the development of affirmative action in higher education in Brazil. The third section includes studies exploring the race and socioeconomic status of applicants and their effects on institutional quality for quota-admitted students. These studies highlight the public opinion on race-based programs and emphasize the prevalence of the racial democracy myth. Given next are a series of studies that focus on the academic performance of affirmative-action applicants and graduates. The fourth section underscores the breadth and depth of studies completed to date on the academic attainment of this group when compared to non-quota students, given the educational and systematic challenges quota 
students face. A brief section provides information on the ENADE exam and other proxies for academic success. The sixth and final section is organized by dependent variable blocks (input and environmental variables) corresponding to the research questions. This chapter demonstrates that while many studies that have been conducted about quota students include some student and family characteristics and a few studies included environmental variables, a gap in the research related to the factors that contribute to the academic success of quota-admitted students continues to exist.

\section{Affirmative-Action Approaches in the U.S. and Brazil}

Over the last 50 years, since the Civil Rights Movement, American institutions of higher education have focused on increasing access and retention efforts among racially and ethnically diverse populations (Fischer, 2010). Despite these efforts, Hispanic and African American students are lagging behind Whites in college completion rates and grade point averages (Steele, 1997). The two main kinds of philosophical arguments used to support affirmative-action programs in the U.S. higher education system are either backward-looking or forward-looking (Boxill, 2003). Affirmative-action proponents argue that systematic institutional racism or, in the case of the United States, de jure and de facto segregation, have contributed significantly to racial disparities and that such programs are one way to provide redress. This paradigm is known as the "backwardlooking" argument (Jackson, 2008).

In contrast, forward-looking arguments are more nuanced. They propose that affirmative-action will lead to "equality and social justice" for groups that are born into impoverished conditions and receiving unequal educational environments (Boxill, 2003; Jackson, 2008). The forward-looking argument seems more acceptable in the U.S. society 
as it appeals to the idea of classism, which, as we will see, is also the preferred viewpoint of some Brazilian people. Class, and not a race, is often argued to be the culprit of the educational, social, and justice inequalities experienced by Afro-Brazilians (Schwartzman \& da Silva, 2012).

Some opposing arguments state that (1) in a color-blind society, affirmativeaction is no longer needed; (2) people need to compete solely on merit; or (3) affirmativeaction is causing "reverse discrimination" (Allen, Teranishi, Dinwiddie, \& Gonzalez, 2000, p.4). Other arguments have an added dimension, asserting that race-based affirmative-action is unfair to the benefiting-student and the school and that the real problem is the K-12 system, which is not adequately preparing minority students for higher education (Sander et al., 2017). Sander et al. (2017) conducted an empirical study of law students and tested the hypothesis that students who are admitted to a school in which they are underqualified or have lower credentials upon admission will perform worse overall than if they had attended a school in which the student's credentials were on par with the average entering scores. This concept is known as the mismatch theory (Heriot, 2011). Others have argued that a diverse campus and classroom benefit all and not just minority students (Jayakumar, 2002).

Mainly for the disadvantaged, higher education provides a beacon of hope and access to the "promised land" to achieve the American Dream (Allen et al., 2000). Opponents of race-based affirmative-action state that middle- and higher-income Blacks are more likely to benefit from the policies rather than lower-income individuals. Boxill (2003) argues that while true, a small group of students could generate change in the minority community. In addition, a "critical mass" of diverse students in higher education 
would reduce racial-tensions and facilitate a better understanding among different races (Jackson, 2008).

In Brazil and India, considering higher education as a ladder for social mobility has been a prevalent argument as their governments implemented more homogenous and race-targeted programs with socioeconomic condition categories (Frisancho \& Krishna, 2016). While the promise of social mobility is tempting, some have argued that in the U.S., minority students who enter universities through affirmative-action programs are more likely to change majors and choose majors that are less profitable and/or prestigious (Heriot, 2011), while proponents of increased access programs challenge the notion that access alone is sufficient (Allen et al., 2000). This narrative is similar to the one in Brazil, as recent studies have confirmed the idea that quota-admitted students are choosing less selective majors and moving into less socially prestigious and lower wage earning professions (Dias Lopes, 2017; Francis \& Tannuri-Pianto, 2012b).

\section{Historical Context of Brazilian Racial Issues}

Colonized by the Portuguese in the 1500 s, Brazil only gained its independence in 1822. For more than three hundred years, Brazil was exploited, its resources were mined, and many of its people were persecuted. In contrast to the Spanish colonies, the Portuguese did not create universities until the royal family arrived (in Brazil) in 1808. In the same year, the first universities were established, initially as medical training centers, and, now, the campuses belong to the Federal University of Bahia and Federal University of Rio de Janeiro (Fávero De Albuquerque, 2006). Brazil was belated in developing a higher education system when compared to other Latin American countries (Schwartzman, 2013). Universities and training centers in Brazil, like in the U.S., were 
instituted for the elite before democratizing access. The impediments were two-fold in Brazil. First, it was late in developing higher education in comparison to other countries (even Latin America), and, second, universal public education was not established until the 1950s (Saviani, 2010; S. Schwartzman, 2013).

Brazil was the last country in the Western hemisphere to abolish slavery in 1888 , and it did so under pressure from other nations vehemently condemning Brazil for its continued practice of enslaving people (Skidmore, 1974). As mentioned by Norma (2011), more than half of all the slaves brought to the Americas went to Brazil when compared to the $6 \%$ who ended up in the United States (Russell-Wood, 1982). A discussion of the demographic make-up of the Brazilian people, the racial democracy myth, and the events that led to the creation of affirmative-action policies in Brazil is given in the following section.

The racial democracy myth described by Htun (2004) assumed that: the disproportionate impoverishment of Blacks and their absence among elites is due to class discrimination and the legacy of slavery, and that the absence of statesponsored segregation, a history of miscegenation, and social recognition of intermediate racial categories have upheld a unique racial order (p. 64). Brazilians have not adopted systematic rules for race definition; instead, there "are hundreds of terms" to describe physical appearance and skin tone (Htun, 2004, p. 64). For purposes of this research project, race will be categorized according to the schema adopted by the Brazilian Institute of Statistics and Geography (IBGE). These categories 
are White, Brown, and Black. ${ }^{10}$ According to Htun (2004), the lack of an official name or classification prevents people from gaining power and visibility. The deliberate practice by the Brazilian government of rejecting a narrowly framed categorization of race is one of the reasons Htun (2004) cites as the cause of delay in the development of racial consciousness among Blacks and Browns and the postponement of the implementation of measures to bring forth racial equality. Affirmative-action is defined as the policies implemented with the goal "of ameliorating the effects of racial inequality" (Darby, 2010, p. 409).

Consistent with Brazil's demographics, the history of Afro-Brazilians is much different from the one experienced by African Americans in the U.S. For example, there was no de jure segregation in Brazil, as seen in the U.S. In 1917, Clayton Cooper, an American visiting Brazil, explained that Brazilians were attempting to eliminate "Blacks and Browns by pouring in White blood" (Skidmore, 1974, p. 74). This attempt at the elimination of races in Brazil by miscegenation is known as the whitening theory, which was a widely accepted concept after the abolition of slavery in 1888 until the 1930s (Skidmore, 1974).

The whitening (racial) theory emerged from Brazilian intellectuals' need to reconcile the large population of Blacks and Browns with the climatic determinism theory of race that claimed superiority of northern European Whites. Climate theory was the European intellectual doctrine interwoven into the Brazilian society that pre-existed

\footnotetext{
${ }^{10}$ Brown is categorized as what would be mixed race in the U.S. However, this is a more complex term. For example, individuals who are Brown do not necessarily view themselves as Black and when forced to make a dichotomous choice between Black and White, more will choose White (Bailey, 2008; Loveman et al., 2012).
} 
the abolition of slavery in 1888 and persisted in the following decades (Skidmore, 1974). Consequently, abolitionists did not give much thought to race, much less to segregation, and instead worried more about legal reforms (Skidmore, 1974).

The philosophy of the climatic determinism was created to explain the economic benefits of Northern Europe in the 1850s. It was proposed that the "higher" races benefited from the best climates, and therefore, the population was more productive (Skidmore, 1974). The tropical weather in Brazil was said to be inferior to that of Northern Europe; thus, Brazil's prospect of economic productivity and harboring a superior race was not feasible (Skidmore, 1974). Racial determinism, which ranked superior and inferior races, was also popular. Unlike Northern Europe and the United States, Brazil had a long history of miscegenation of races, which led to a multi-race society, and while the elite was concerned about the effects of this mixing, they could not change this because there was no option to separate races again (Skidmore, 1974).

This preoccupation with superiority and purity of race was ubiquitous in the world at the time. Many international visitors expressed disdain and concern about the miscegenation of races, including Gobineau, Louis Agassiz, and Jose Ingenieros (Skidmore, 1974). Silvio Romero and Nina Rodrigues were Brazilian intellectuals that grappled with the dissonances of the Northern European superiority and the Brazilian reality of miscegenation (Skidmore, 1974). Silvio Romero believed that the mestiço or 
mullato (referred to mixed race hereinafter) was a subpar race but that the African race had contributed to the Whites' ability to be able to withstand the tropical climate. ${ }^{11}$

Physical characteristics, such as hair texture, facial and skin color along with clothing, and acquaintances, were social status determining factors - characteristics assessed by those looking at them (Skidmore, 1974). A mixed-race individual could achieve higher social status if he or she could pass, i.e., act like those in the more upper social class, and this led to the creation of the racial democracy myth or that of the nonbinary race classification system, miscegenation, and lack of segregation that caused a harmonious racial equality in Brazil.

In 1872, "there were almost three times as many free [individuals] as slaves among the colored population" (Skidmore, 1974, p. 41). As a result, there were structures in place that allowed for the coexistence of free people of color and White people. Some mixed race people were able to climb the social ladder as a result of the reasons explained above. The thesis of whitening theory was further supported by a national push to increase White immigration to Brazil, including private entities encouraging the migration of Italians to work the fields (particularly in southern Brazil). The government later oversaw this effort. Brazilian government officials worked hard to change the Brazilian international image by attending world exhibits (fairs), inviting foreign visitors, and attempting to woo more White immigrants to Brazil to continue the whitening

\footnotetext{
${ }^{11}$ Mestiço is a term used to describe some of the mixed-racial background, which can include mullato. In the IBGE (Brazilian census), this is categorized as the Brown (pardo) race. In Brazil, mullato is the term used to describe the mixing of White and Black races.
} 
process (Skidmore, 1974). Brazil's image at the time was not positive, given the mixing of races and its perceived inferiority to the northern Europeans.

Decades later, after the implementation of affirmative-action policies, Htun (2004) argues that this precise fluidity and the government-sponsored idea of miscegenation of races contributed to the delay in recognizing the social injustices against Brown and Black Brazilians. Specifically, Htun (2004) concluded that it was not a group of activists or pressure from voters that led to the creation of affirmative-action programs. It was a combination of a sympathetic president, Fernando Henrique Cardoso, who studied race relations for his doctoral dissertation, social mobilizations (i.e., AfroBrazilians activists), and pressure from the international community in the World Conference on Racism, held in Durban, South Africa in 2001 (Htun, 2004). A summary describing some key historical events in Brazilian history can be found in Table 2. 
Table 2.

Key Events in Brazilian History

\begin{tabular}{|c|c|c|}
\hline Year & Event & Reference \\
\hline 1500 & Colonization of Brazil by Portugal & \\
\hline 1808 & Establishment of the First University & (Fávero De Albuquerque, 2006) \\
\hline 1822 & Gained Independence from Portugal & \\
\hline 1872 & $\begin{array}{l}\text { "Three times as many free individuals as slaves } \\
\text { among the colored population." }\end{array}$ & (Skidmore, 1974, p. 41) \\
\hline 1888 & Abolishment of Slavery & (Skidmore, 1974) \\
\hline 1946 & Establishment of the public education system & (Saviani, 2010; Schwartzman, 2013) \\
\hline 1997 & $\begin{array}{l}\text { Fernando Henrique Cardoso (then President) } \\
\text { publicly acknowledges that racism exists in Brazil }\end{array}$ & (S. A. Dos Santos, 2014) \\
\hline 2001 & $\begin{array}{l}\text { World Conference on Racism in Durban, South } \\
\text { Africa }\end{array}$ & (Htun, 2004) \\
\hline 2001 & First State University Established Quota & (Htun, 2004) \\
\hline 2008 & Law of Social Quota & Law No 12.711(Brazil, 2012) \\
\hline 2012 & $\begin{array}{l}\text { Law of Social Quota is ruled constitutional by the } \\
\text { Supreme Court }\end{array}$ & Law No 12.711(Brazil, 2012) \\
\hline
\end{tabular}

\section{Note: Table was created by the author}

With an increase in the access to higher education for Black and Brown Brazilian students, it is essential to understand what factors influence their success. As the following studies illustrate, much attention has been given to comparing quota vs. nonquota achievement, but little has been done to understand what is influencing affirmativeaction student academic performance, particularly given the relative success documented in previous studies. Understanding these factors is important as the primary goal of the Law of Social Quotas is to promote greater access to Black and Brown students, but the 
law narrowly defined how it seeks to generate social mobility through education. ${ }^{12}$

Therefore, by knowing what factors influence the success of these students, university administrators can better serve this population. The needs of quota-admitted students are likely different from that of non-quota students. These unique needs merit a separate study of this individual population.

A review of the literature demonstrated that previous research focused on student and family characteristics, but none of them included the role that environmental or college involvement variables play in determining its impact on student success.

Research on student retention and college achievement in the United States have demonstrated positive association between social support (Crisp, Taggart, \& Nora, 2015; Gloria, Castellanos, \& Rosales, 2005; Tovar, 2014) and individual involvement (Astin, 1993) but a negative association with economic barriers (Wohlgemuth et al., 2006). The present study aims to determine which factors (e.g., student and family characteristics, social support, institutional environment, and economic factors) influence quota students' exit exam achievement. Given the recently reported aggregate comparative success of these students, what variables affect their academic performance?

\section{Race or Socioeconomic Status}

Race is often conflated with class when discussing affirmative-action policies in Brazil, and this causes some confusion (Schwartzman \& Da Silva, 2012). In the first stages of implementation, Brazil's quota system was supposed to use race as a criterion,

\footnotetext{
${ }^{12}$ While the Law of Social Quotas has evolved with a primary focus on socioeconomic status, with race as a secondary criterion, the Ministry of Education maintains that quotas are the best way to combat educational inequality (http://portal.mec.gov.br/ultimas-noticias/222-537011943/20781-ministro-diz-queso-educacao-pode-combater-desigualdade).
} 
but it evolved to using public high schools, as a proxy for students' socioeconomic status and race (Schwartzman \& Da Silva, 2012). There is also a high correlation between race and socioeconomic status in Brazil (Schwartzman, 2007). For this reason, some Brazilians favor the use of the socioeconomic status rather than race in the quota system (Schwartzman \& Da Silva, 2012). The racial democracy myth maintains that Blacks and Browns are more impoverished due to their socioeconomic status and not racial discrimination as Brazil did not experience segregation like the United States or other countries (Htun, 2004). This aversion or hesitation to address the race issue is similar to the approach the United States has opted to take. It is easier and less controversial to focus on class than race. I will not address the legal challenges of affirmative-action in this dissertation, but in both countries, discrimination based on race is typically unconstitutional, and race-based programs may be constitutional in the right circumstances.

The sudden change in policy elicited strong responses from the public. Maggie and Fry (2004) reviewed a prominent newspaper's - O Globo's - letters to the editor between 2001 and 2002 after an unexpected top-down state law in 2001 mandated that public universities reserve $40 \%$ of spaces to Black or Brown students in the state of Rio de Janeiro. Maggie and Fry's (2004) study aimed to understand public opinion on this matter. They argued that the public failed to realize two things. The first was that it was unlikely, if not improbable, that affirmative-action quotas would ever be implemented through a top-down approach, given Brazil's democratic government. The second was that Brazilians underestimated the change in "key areas" in the evolution of race. For instance, Brazil does not have one mixed race but distinct races. Their findings on the 
analysis of the letters to the editors were grouped into six themes: (a) the law is unconstitutional; (b) discrimination, albeit positive, goes against the Brazilian tradition (alluding to the racial democracy myth); (c) there is public confusion about how to selfdeclare their races; (d) inequalities between Black and Whites stem from the lack of opportunities and socioeconomic status; (e) law results in reverse discrimination against less privileged Whites; and (f) affirmative-action is humiliating for those benefitting from it (Maggie \& Fry, 2004). ${ }^{13}$ While no discernible framework was used, a practical approach was adopted to review the historical context during the passing of the state law and the statistics used to illustrate the inequalities experienced.

Earlier, this dissertation discussed the two philosophical approaches used by proponents of affirmative-action: forward-looking and backward-looking. Maggie and Fry (2004) also mention these philosophies without using these precise terms. They claim that the writers fall into two camps. Some attribute to slavery the lack of opportunities and inferior educational offerings of Blacks. ${ }^{14}$ This explanation aligns with the backwardlooking philosophical approach of affirmative-action. Others attribute the lack of current opportunities as the cause of the discrimination after the abolition of slavery and the culprit behind the reproduction of inequalities; thus, the latter view aligned better with the forward-looking viewpoint. Regardless, Maggie and Fry (2004)'s study demonstrated the challenges and strong opposition from some Brazilians to a state-wide affirmative-action policy. These sentiments were magnified with the Law of Social Quotas in 2008.

\footnotetext{
${ }^{13}$ For example, one writer from Maggie and Fry study asked: "If my grandmother is Black, but my skin is White, am I Black?"

${ }^{14}$ Calling special notice is how letter writers conflated race with socioeconomic status.
} 
Although class or socioeconomic status has taken a front seat in this quota system, race is a secondary consideration, as Figure 1 shows. This is particularly problematic in Brazil because of how people self-classify, as illustrated by Maggie and Fry's (2004) study. A binary categorization and acknowledgment of race as it is understood in the U.S. context is still a novel concept to many Brazilians. Many visitors today believe that mixed-race people make up the primary demographic of Brazil (Guimarães, 2003). This makes it inexplicably tricky for natives of Brazil to accept and see that racism exists. Tavolaro (2008) argues that race-based affirmative policies in Brazil use "U.S. multiculturalist terms [and] is a clear example of cultural imperialism and symbolic violence" (p. 147). This is one of the arguments given by the opponents of race-based affirmative-action programs in Brazil.

Alternatively, in their work, Menin et al. (2008) found a small minority of university students who argued that these aggressive affirmative-action policies are necessary in higher education to redress and repair the damages and lack of opportunities provided to this segment [Blacks] of the population. This particular reasoning follows the backward-looking philosophical approach to the affirmative-action mentioned before. In their qualitative study, Menin et al. (2008) analyzed various perspectives that university students from a public university in São Paulo had about quotas. For the most part, the interviewed students were against quotas as it clashed with their values of fairness, equality, and self-effort (merit). The arguments took one of the following three forms: (a) quotas are unconstitutional; (b) quotas will bring down the value of the university; and (c) the entrance exam provides a fair and merit-based entry. These findings are congruent with that of Maggie and Fry (2004). 
Once implemented, how did students and administrators internalize the quota system? Schwartzman and Da Silva (2012) used a qualitative methodology to understand this process using data previously data gathered for a different purpose. Da Silva used the interviews of 18 administrators, deans, and admission officers in five Brazilian institutions of higher education that had all adopted affirmative-action policies. Schwartzman used the data from her dissertation, in which she interviewed 28 students from one of the first universities to adopt the affirmative-action policy (Schwartzman \& Da Silva, 2012). Administrators cited more class-based reasons in support of affirmativeaction than race-based ones. One dean stated that a race-based only system was out of the question as this would not be embraced by university administrators. Schwartzman and Da Silva (2012) acknowledged that racial diversity is hard to support because of the "blurred" racial lines in Brazil (p. 36). Researchers found that students who supported quotas did so for class reasons, while others simply were not convinced that quotas were necessary. In defending the argument that quotas should only focus on socioeconomic status as a criterion, one interviewed student stated that if a Black student is admitted to a federal university, others will automatically assume that the said student came through quota (Schwartzman \& Da Silva, 2012). This point supports the racial democracy myth. Interestingly, Schwartzman \& and Da Silva did not mention a meritocracy or lowering of standards by allowing quota-students to enter; this could be based on the questions asked or the selected excerpts used by the authors. Schwartzman and Da Silva (2012) maintained that their study suggested "[ $[\mathrm{t}] \mathrm{hat}$ the idea of diversity is experienced as a class rather than as racial diversity, stressing the salience of class boundaries in Brazil" (p. 34). 
Since the 1972 census, the categorization of race in Brazil has included Black, Brown, and White, but there are other categories as well, including Asians (yellow) and indigenous, which are ethnicities and not races (Guimarães, 2003). Consider the whitening effect or phenomenon, as described by Luisa Schwartzman (2007). Schwartzman (2007) discovered that Brazilians of higher socioeconomic status were more likely to label their (non-White) children as White than their less-educated counterparts. This point exacerbates the racial classification challenges in Brazil. It also supports the idea of racial superiority and a prevailing desire to "pass"; considering the previous racial divide and the achievement gaps in Brazil, this is not startling.

Furthermore, this classification creates problems for Brazilians in determining how to identify as one color or the other. Because some quotas are based on selfselection, students may "contribute to further to keeping the benefits away from candidates who suffer from racial discrimination but do not see themselves as 'Black enough' for quota purposes" (Schwartzman, 2009, p. 224). Supporting Schwartzman's (2009) assertions, Bailey (2008) found that when given a chance to choose a race in an open-ended question rather than the set categories provided by the government, $44 \%$ Brown people chose White rather than mixed. In another study, using a nationally represented sample when given the choices used in the IBGE for race-classification (White, Brown, or Black), 52\% reported being White. For all of those who selected Brown, a follow-up question was presented as a binary option (Loveman, Muniz, \& Bailey, 2012): "Which of these terms best describes your colour or race?" This created a whitening effect, bringing the percentage of people identifying as White up to $68 \%$ (Loveman et al., 2012, p. 1473). 
The Law of Social Quotas was passed in 2008 but implemented in 2012 after the Supreme Court ruled that it was constitutional. It applies to federal universities. Other state and municipal universities implemented voluntary or state-mandated quota programs. Some universities decided to implement the new quota system by allowing the students to self-declare Black or Brown, while others such as the University of Brasilia (UnB) opted to convene a panel to determine, based on photographs, whether the applicants were Black or not (Chor Maio \& Ventura Santos, 2005). UnB is a federal university and early adopter of racial quotas, and it chose to implement this panel as a way to keep people from abusing the program. This article focused on the struggles of determining who is Black or Brown in Brazil and who gets to decide this classification (Chor Maio \& Ventura Santos, 2005). Although not mentioned in this article, this process was widely publicized in the Brazilian media after the previously mentioned twins applied under the panel classification process. The panel admitted one of the twins but denied the other. This example illustrates the difficulty of judging race based on the physiognomy, but at the same time, it shows the distrust of the self-declaration method. Finally, Chor Maio and Ventura Santos (2005) conclude that while race classification is seen as a social construct and as a form of liberation from racism, state action disguised as classification and order of who is Black or not, possess immense power to affect public policies. The idea that people are not capable of opting into the quota seems surreal and bizarre from the outside, but the fear that people will abuse the system, whether true or propaganda, has been successful in dividing the nation. UnB no longer uses this method. Instead, students can self-identify. Chor Maio and Ventura Santos (2005) contend that the university, with help from the state, attempted to use "science" to determine the race 
through its use of an anthropologist in the panel. The university sought to legitimatize the idea that a photo could be a determinant of race by the examination of skin tone and facial features. Skidmore (1974) and later Eakin (1985) explained Silvio Romero's theory of race and the use of science to exclude and create a scientific reason for considering the mixed-raced individuals in Brazil as racially inferior.

Even if self-declaration is deemed better or more appropriate, what happens when the applicants who could benefit do not self-identify as such? Bailey (2008) used a national probabilistic sample $(n=2,362)$, attitudinal survey, and a separate questionnaire to find out how every-day Brazilians self-identified, both when provided set categories and when the question was open-ended. Using a binomial logistic regression to predict the choice of Black over White by mixed-race people, she found that mixed-race people do not identify as Black. Researchers determined this by asking the same respondent about their race in different ways (a) using the census categorization, (b) open-ended, and (c) asking: of the two categories (White or Black), which best describes your race? Additional questions included showing photographs and asking participants to choose the person's race.

Consequently, this group would be more often excluded from the benefits of affirmative-action programs. Also, most respondents felt that only Blacks should benefit from it, limiting the program altogether (Bailey, 2008). There is no debate that people who are mixed (Brown) face discrimination; however, self-elimination from the program could have a significant impact on the success or failure of such policies. This is another study that illustrates the challenges of race categorization in a country in which the 
narrative focuses on classism and where many continue to hold on to the racial democracy myth.

Like Schwartzman and Da Silva (2012), Dos Santos (2007) also interviewed students and administrators to learn about their perceptions of the affirmative-action policy at a particular university. Dos Santos (2007) interviewed professors at all levels, and when asked if racism existed in Brazil, $86 \%$ said yes, but when asked if they supported the quotas at UnB, $56 \%$ said no. The top two reasons for their dissent were (1) that students should be admitted based on merit, and (2) that Black and Brown students do not have access to higher education because they are poor and not because of their race. Similar results emerged when the researcher interviewed graduate students as well. About $55 \%$ of students were against quotas, and their two top reasons were (1) Black and Brown students have access to inadequate public education and (2) they are not admitted not because they are Black or Brown but because they lack the education (Dos Santos, 2007). Although Dos Santos' (2007) study was small and focused on one university, the results fit with those from other studies. The caveat here is that he used graduate students, of which $40 \%$ graduated from public basic education and $56 \%$ from private education (primary and secondary). For this reason, it would be interesting to investigate and separate the answers based on which type of school the student attended.

The results, yet again, point to Brazilians' belief in classism and their inability to address the effects of racism. To measure or determine if racial income inequalities exist and the differences between intra- and inter-metropolitan areas, Silveira and Muniz (2008) used data from the national household sample survey in 2008. While controlling for education, occupation, sex, and socioeconomic status, there was still a significant gap 
in income between racial groups. The authors attribute the unexplained differences to racial discrimination. Silveria and Muniz (2008) acknowledged that other confounding variables related to race can be the cause of this income inequality. This and other studies with similar findings make it hard to argue that the racial democracy myth is real.

\section{The Trajectory of Underrepresented (Low Socioeconomic Students) in Higher}

\section{Education Before Implementation of Affirmative-Action}

In the Brazilian context, Viana (1998) studied university students from low socioeconomic status, specifically children of working-class parents, to understand what factors or circumstances made it possible for students to achieve this unlikely educational achievement. Using a biographical narrative as her methodology, Viana studied seven students (5 undergraduate and 2 graduate) and described her findings in three interrelated sections: the family, student-son/daughter, and school. Lahire and N. Elias guided her research on the interdependence of factors and the idea of social configuration. As cited by Viana (1998), like Lahire (1995), Viana did not find a direct relationship between parental investment in education and academic success in children. The race of the individuals was not disclosed in the study.

Portes (2001) performed a qualitative study using ethnographic methods to determine the school and university pathways of five low socioeconomic Federal University of Minas Gerais students in highly selective majors. Portes cited the works of Laurens (1992) and Viana (1998), among others, as inspiration. Emergent themes include student life on and off campus, financial conditions, student-faculty relationships, peer relationships, and academic performance (Portes, 2001). The figure of the mother and her role and influence in the schooling of the students is highlighted. The author cautions 
against trying to reduce the experiences of students from low socioeconomic backgrounds to data points and comparing the factors or experiences of middle or high socioeconomic status experiences (Portes, 2001).

Viana (1998) and Portes (2001) focused on the definition of the socialization of the individuals as described by Norbert Elias, who said that people are socialized by the environment and family but also have internal characteristics such as individual personalities, thoughts, and behaviors are that are not directly related to the familial links (Zago, 2000). These interactions, both past and current, are interdependent and should be interpreted together rather than as individual determinants (Nogueira, 2013; Viana, 1998; Zago, 2000). Andrea Leão (2007) argued that the person and their interactions with society need to be studied in a historical context, as both individuals' and societies' habitus are interconnected (as cited in Hunger, Rossi, \& Souza Neto, 2011).

Combined, these works focused on the higher education performance of people with low socioeconomic status. They demonstrate that individuals' social networks have positively impacted the trajectory of students who made it to the university level. Though there is some discrepancy in the role of parents in the transmission of cultural capital and educational practices to their children, as long as qualitative studies cannot be generalized, the emergent themes can be used to paint a broader picture of what factors contribute to the success of students from low socioeconomic background in the university setting at the macro level. ${ }^{15}$ Additionally, I cannot ignore the lack of discussion on race in these works, which will be used in the present study.

\footnotetext{
${ }^{15}$ Cultural capital consists of the skills, education, norms, and behaviours acquired by members of a social group, which can give them economic and other advantages (Barker, 2004).
} 
While the authors in the previous studies have focused on the individuals as the unit of study, I have chosen to paint a broader picture for two reasons. First, it is important to highlight that at the time of these studies, large-scale affirmative-action policies were not in place and the number of students from low socioeconomic classes that were able to overcome the barriers and obstacles would be arguably lower than today, given the new policies in Brazil. Second, given the vast amount of information and data collected by the Brazilian government since 2004, there is an abundance of data that can be used to identify the trends on the academic success of large numbers of individuals.

This dissertation will not employ one of the sociological frameworks used in the studies previously discussed (Viana 1998; Portes 2001). The objective of the review of such literature was to understand what factors contributed to the trajectory of underrepresented students in attaining higher education given their circumstances, preceding the implementation of affirmative-action programs.

\section{Academic Performance of Affirmative-action Students}

As the review given below will demonstrate, there is a fixation on the part of researchers to compare quota and non-quota student achievement continuously as a way to prove or disprove that quotas are lowering the academic institutions by admitting less prepared students (I refute this last claim although this is the narrative used by opponents of quotas). On the other hand, some researchers appear to want to legitimize students' place in higher education. A direct comparison between the two groups does not legitimatize quota students' place. Instead, it propels them into a competition with nonquota students. These views can be interpreted as the extension of the pro and anti- 
affirmative-action arguments. As explained by Peixoto, Ribeiro, Bastos, and Ramalho (2016), a gap in performance should be expected. The narrow margin of the gap wherever it exists and the overperformance of quota students in some areas combined with the weak predictiveness of entrance scores and low evasion rates of quota-students merit a study to understand the variables that contribute to the success. Other studies have used an "us vs. them" lens, giving credence to the argument that to participate in higher education, quota beneficiaries are required to fit in and perform according to the rules that have long kept them out of this realm.

Recent studies have shown the academic achievement of quota admits in certain cases to be on par or close to traditional admits in terms of exit exam scores (Valente \& Berry, 2017), entrance scores (Childs \& Stromquist, 2015), and pass rates for the attorney passage exam, which is equivalent to the bar exam in the United States (Ribeiro, 2016). An earlier study of UNICAMP (State University of Campinas) demonstrated that students who attended public high schools exhibited a higher relative performance than those who attended private high schools (Pedrosa et al., 2007). Quota students tend to underperform on class averages, ENADE scores, and lower entrance scores in majors that are more prestigious and lucrative, such as the sciences (Peixoto, Ribeiro, Bastos, \& Ramalho, 2016). For this study, the researcher is interested in understanding the aggregate variables that contribute to the broad success of quota admits. Success is defined as the ability of students who enter federal universities with lower financial resources and arguably less academic preparedness to still graduate.

The State University of Campinas (UNICAMP), while not directly impacted by the subsequent 2008 Law of Social Quotas, devised its affirmative-action plan to increase 
equity in its admission practices following the findings of Pedrosa et al.'s (2007) study. The study sought to determine the impact or influence of educational and socioeconomic factors on relative performance at UNICAMP. Using student admission records $(\mathrm{N}=$ 6,701) between 1994 and '97 at UNICAMP, Pedrosa et al. (2007) used the Hierarchical Linear Model (HLM) and a backward elimination process to examine the relative performance using a standardized measure of the difference between entrance and exit academic ranks and other relevant variables, prior to entering UNICAMP (socioeconomic index, type of secondary school, type of courses in secondary school, attendance in college preparatory class [similar to SAT preparatory courses], work/no work, economic participation in the family, speaking a foreign language, and day vs evening attendance in high school). The authors concluded that students coming from disadvantaged educational and socioeconomic backgrounds exhibited a higher relative performance when compared to their peers. Pedrosa et al.'s (2007) study found eight characteristics that were significantly, positively associated with higher relative performance. They are as follows: "(a) belonging to the lower tiers of the family socioeconomic-educational index; (b) having graduated from the public secondary system; (c) having studied at technical or teaching credential schools; (d) not having attended preparatory courses; (e) not speaking a second language; (f) having studied full time in high school; (g) being a female; and (h) being younger" (p. 79).

The authors concluded that this study proves to be "a clear alternative to the quota systems being adopted by some universities in Brazil [mainly] because it respects the academic autonomy of the universities [and preserves] the academic standard of the student body" (p. 14). Race was not used in the model because this information was not 
available. This study later led to the development of a bonus-point system affirmativeaction program based on public school attendance and race.

These findings should be interpreted with caution, as UNICAMP is one of the top public universities in Brazil, and the students from this sample (1994-1997) would have had to arguably overcome substantial obstacles before gaining admission through traditional admission practices. Additionally, this study controlled for gender and age but not socioeconomic status and race, both of which are traditionally viewed as appropriate covariates. This study also does not examine environmental variables during the college experience. This is the only study that examined the relative performance and not absolute performance. In other words, students from disadvantaged backgrounds had greater growth while at UNICAMP but may not have achieved similar levels of absolute performance. The decision to use a ranking system was deliberate on the part of the authors for two reasons (a) there are differences in the academic performances between majors and an aggregate comparison without controlling for major, and (b) because the number of students per major was not even, the discrepancy could significantly impact the averages (Pedrosa et al., 2007).

More recently, Childs and Stromquist (2015) used a comparative framework to analyze the impact of quota and non-quota students in three universities - University of Bahia, University of Brasilia, and the State University of Campinas. They sought to determine (a) if quota students diminished the quality of their institutions, (b) the impact of quotas on campus diversity, and (c) the predictive validity of the entrance scores. They found that for the most part, quota students performed relatively well when compared to non-quotas, and the largest disparities were found in math and science majors across the 
three institutions. They concluded that quotas increased the number of Black and Brown students and that the predictive validity of the entrance scores was weak. Given the quota students' success, these findings are similar to the ones from Bezerra (2010) and Cardoso (2008). This study used average grades to make comparisons and used a performance index to visually see the difference among groups (because grades vary from university to university). We are not able to see if the differences are statistically significant, and the measurements of the grades were in averages. In other words, the average scores for all non-quota and quota students in nursing were used as the unit of comparison. This is problematic because outliers could substantially influence the average. Nonetheless, this study provides a comparative view of the academic and diversity impact of the quotas.

In a single university study, Ribeiro (2016) analyzed the impact of quotas in the State University of Rio de Janeiro Law school (UERJ). Rio de Janeiro was the first state to adopt an affirmative-action law for Black and public-school students in 2001. Ribeiro (2016) found that quota students and non-quota students had similar graduation rates, but quota students took longer to complete their degree and scored lower by $7 \%$ on the $\mathrm{OAB}$ exam (equivalent to the American bar exam). Additionally, this study found that quotaadmitted students had strong positive chances of passing the law certification exam without hurting the displaced students. ${ }^{16}$ The displaced students were measured using the cut off at UERJ, using the information from the OAB to see what similar students who did not attend UERJ got in their license exam or if they even passed at all. This study

\footnotetext{
${ }^{16}$ Students who did not attend UERJ because of the introduction of quotas; in other words, these students would have been admitted prior to the implementation of quotas.
} 
used data from UERJ and the OAB to determine if displaced students performed worse in the certification exam and found that they did not.

In a single federal university study conducted in Bahia $(\mathrm{N}=26,175)$, when comparing quota to non-quota academic performance as a measure of average scores per major (similar to GPA), quota students performed significantly worse, i.e., $6.6 \%$ points lower than their non-quota peers (Peixoto et al., 2016). A t-test was used to compare the mean scores of quota and non-quota students. When analyzing by major, quota students outperformed in 13 majors (mostly in the humanities and with low prestige), while nonquota student exceeded in 39 majors (mostly in fields with a higher perceived influence such as the hard sciences). For 29 majors, the difference was less than 5\%. Using these results, it is possible to summarize that in a little more than $50 \%$ of the time, quota students either outperform or are on par with non-quota admits. The authors conclude that these results point to the inadequacy of the education provided by the public K-12 system, which could lead to the Law of Social Quotas becoming an eternal rather than an ephemeral solution. There were no controls set to account for socioeconomic status, race, previous academic achievement, age, or gender. Additionally, all quota students, regardless of the type, were placed into a general category, which can confound the results.

Two studies by Waltenberg and Carvalho (2013) and Valente and Berry (2017) aimed to compare the academic achievement of quota and non-quota students using the national student performance exam (the Exame nacional de desempenho de estudantes or "ENADE"). This exam is mandatory for all graduating students who are majoring in the particular major being evaluated by the Ministry of Education at any given year. All 
students from those majors in all Brazilian institutions of higher education have to complete the exam in order to receive their diploma. This exam as a measure of success has two disadvantages; first, it is not tied to a student's college career and, second, there is no set passing rate.

Waltenberg and Carvalho (2013) used the 2008 dataset $(\mathrm{N}=167,704)$ for the ENADE exam to evaluate the differences in performance between quota and non-quota students. They grouped majors into low, medium, and high selectivity and did not set controls for income, age, work status, or university, selectively. The authors intentionally used parental education as a proxy for socioeconomic status. The study used the Ordinary Least Squares (OLS), with the ENADE score (general knowledge) as the dependent variable and gender, race, type of public high school, parental education (a combined score), and entrance type (affirmative-action vs. traditional) as the independent variables. Additionally, they used a combined score to measure parental education. Their results indicated that there was a significant difference of $8 \%$ in the scores of quota when compared to non-quota students in public universities and no difference in performance in the private sector; but the researchers concluded that this was a reasonable cost to society for providing more access to education to unrepresented groups in an effort to increase equity (Waltenberg \& Carvalho, 2013).

Valente and Berry (2017) used the same data from different years to analyze the same question, making significant changes to the model per the previous critique. In their study, they used data from 2009-2012 and controlled for race, gender, family income, public school, mother's education, father's education, region, and working students. The independent variables were affirmative-action; there are several types. The dependent 
variable is the overall score of the ENADE, which assesses general education and is the same exam across all majors. OLS data was analyzed for private and public universities separately. Students admitted through public high school quotas and a combination of race and social quota (based on socioeconomic status) performed better than non-quota, everything else being equal. In public universities, students who entered via the incomebased affirmative-action policy and others (comprised of mostly students with special needs) performed worse. The Ministry of Education collected the data used in this study through a socio-economic questionnaire given to students months before taking the exam. This tool was the same questionnaire used by Waltenberg and Carvalho (2013) and is used in the current study as well.

Based on these studies, few people can argue with the quota students' relative success. It can be understood that in addition to not diminishing the quality of public higher education, quotas are increasing access to Black students, who, despite representing over $50 \%$ of the population, remain grossly underrepresented in the higher education sphere. Brazil has been aggressively implementing the Law of Social Quotas since 2012 nationally and in the early 2000s voluntarily with ambitious goals to redress oppressed and underrepresented populations. However, there is a paucity of research on what has influenced the achievement of quota students. Instead, intense focus has been placed on comparing their performance to others. There is widespread knowledge that students entering higher education through the public school system may be underprepared, but the recent studies discussed above show that their achievement has been close to, if not on par with, non-quota students, except in some cases in sciences or 
other high prestige majors (Cardoso, 2008; Childs \& Stromquist, 2015; Pedrosa et al., 2007; Ribeiro, 2016; Valente \& Berry, 2017; Velloso, 2009).

Lastly, a general critique to most previous studies referenced is that quota students are not being judged on the university pass rate or graduation but, rather, to nonquota admits' performance. What is the purpose of the Law of Social Quotas if, while allowing underrepresented students to enter higher education, the measure of success in these studies is made relative to those who are overrepresented? In an effort to provide clarity to the exams used in Brazil, the next section discusses academic success measures such as the vestibular, the ENEM, university grades, and the ENADE.

Measures of achievement. The vestibular and ENEM are two types of entrance exams taken into consideration for admission into institutions of Higher Education in Brazil. The vestibular was implemented in 1911. After its first implementation, 50\% failed the exam. This was a deliberate attempt to exclude those who did not have adequate knowledge to pursue higher education (Xavier, 2014). The ENEM was originally established to assess K-12 learning and later became an entrance exam. In 2001, the government expanded access to ENEM by waiving its fee for students from public schools and further expanded access in 2004, when it made it a requirement for students interested in being considered for the PROUNI, the program that gives federal funds to students attending private universities (Xavier, 2014). In 2010, the ENEM was implemented as part of the Unified System of Admission (Sistema de Seleção Unificada (SiSU) with the goal of offering an alternative to individual vestibular scores that were previously administered by individual universities and by major (Aguiar Bravo, 2017). 
The vestibular is not going away just yet. While more universities (around 100) are accepting the ENEM as part of the SiSU system, many still encourage students to apply via the university-specific exam (ENEM ou Vestibular? Descubra qual a melhor opção para você [ENEM or Vestibular? Find out the best option for you], 2018).

In a single university study at the Federal University of Mato Grosso do Sul (UFMS), researchers used the ANOVA and OLS to determine the variances explained in the vestibular that are associated with socioeconomic characteristics (Quevedo-silva \& Sauer, 2009). The variables analyzed that significantly contributed to the vestibular score were the high school type, how many times you have completed the exam (vestibular), mother's and father's educational attainment, knowledge of English, completion of a vestibular pre-preparation course, number of books read, and working status. These variables combined account for $23 \%$ of the variance in the vestibular score. Previous academic achievement was not included in this study.

Verhine and Dantas (2009) described the ENADE as an imperfect exam but cite three reasons why it should be used: (a) there is at least some type of assessment of the higher education sector even if it is flawed, (b) through the exam, a large amount of data is gathered on the students, and (c) some form of assessment is better than none (Verhine \& Dantas, 2009). The exam comprises 40 questions and takes place over four hours. It has been reported that in certain cases, the difference between the incoming student and the graduating student score of the same major varies very little, calling into question the validity of the exam (Schwartzman, 2005). Additionally, the items on the exam have no external validity, or the reliability information is provided by the Ministry of Education. Professors in each discipline contribute to the construction of the exam questions. Even 
with these flaws, no other assessment applicable to all or a sample of the Brazilian higher education students can provide a broad picture of students' aggregate performance.

Others have utilized grades to assess achievement. Grades vary by professor, institution, and major. A few of the studies cited have used average grades as a measure of academic success (Cardoso, 2008; Childs \& Stromquist, 2015). One study (Peixoto et al., 2016) used a measure that is comparable to GPA (grade point average). Another used a relative measure of success, taking into account the students' prior achievement, the only study (Pedrosa et al., 2007) identified by the researcher to do so.

\section{Key Research Question Variables}

This fifth and last portion of the literature review organizes the independent variables into blocks that correspond to each research sub question. The variables in the current study emerged from the literature. The blocks include student characteristics, family factors, high school variables, pre-college variables, social support variables, institutional support variables, faculty support variables, economic variables, and individual involvement variables.

Input factors. These include Blocks one, two, and three.

\section{RQ1: What influence do entering student characteristics and family demographics have on performance in the overall ENADE score of quota-admitted students?}

Age, sex, and race have been linked to student performance. In a single university study, Pedrosa et al. (2007) determined that being female and younger were associated with higher relative performance in GPA (a ranking system was used to standardize across different majors). Valente and Berry (2017) found that in public university engineering majors, being female had a more significant adverse effect on performance 
than being admitted through quota. In a single university study, Francis and TannuriPianto (2012) found that female students had a higher GPA than male students regardless of the mode of admission. In general, the effects of sex on academic performance are mixed. In a study conducted at the State University of Rio de Janeiro, women were underrepresented in science and engineering programs and overrepresented in other prestigious majors; however, they underperform when compared to men in the university entrance exam (Mendes Junior, De Mello e Souza, \& Waltenberg, 2016).

In a single university study conducted in Rio de Janeiro, Mendes Junior et al. (2016) found income to be the most influential variable associated with students' entrance score, followed by high school type, location/neighborhood, parents' educational level, race, and gender. Additionally, with everything else held constant, Mendes Junior et al. (2016) found a significant difference in the scores of Black and White students. Lastly, when controlling for gender, neighborhood, income, father's and mother's educational levels, race, school type, and major, quota-admitted students had increased entrance scores, a statistically significant positive effect (Mendes Junior et al., 2016). Like in Pedrosa et al. (2007)'s study, the authors said the result came as a "surprise" (Mendes Junior et al., 2006, p. 323). The authors of this study argued against the implementation of quotas because the students being admitted were not performing on par with non-quota students in the entrance exam score and, in general, would not be admitted to UERJ. A limitation of this study is that it does not look at the performance of students after entering, which other studies have been demonstrated to be close to, if not on par with, non-quota admitted students. Another limitation includes not controlling for age and using a socioeconomic variable that is not standard. For example, the authors took the 
traditional measure of income and divided it by the number of people who live in a household. This is the first study where I have seen this measure of income, but I am not sure how or if it impacts the results.

RQ2: What influence do high school variables (location, type [public vs. private], traditional vs. non-traditional) have on performance on the overall ENADE score of quota-admitted students?

About seventy percent of students entering public universities through affirmative-action quotas graduated from public high schools when compared to the fiftyfour percent of non-quota admits that graduated from private high schools (Dias Lopes, 2017). In various studies on affirmative-action students, socioeconomic status is a consistent barrier to achievement and entrance (Dias Lopes, 2017; Francis \& TannuriPianto, 2012a; Mendes Junior et al., 2016).

RQ3: What influence do pre-college variables (evening student, living on-campus, racial quota, college major...) have on performance in the overall ENADE score of quota-admitted students?

In this model, these variables can be interpreted both as input and environmental factors, as per Astin I-E-O model (1993). He referred to these versatile variables or this entire block as "bridge." Time of attendance (night vs. daytime), major-selection, living on campus, and academic scholarship upon entering were selected as the pre-college variables in this study. Previous studies found that students attending university at night tend to work full-time or have other financial and family obligations that prevent them from studying full-time (Pereira dos Santos, 2011; Terribili Filho \& Nery, 2009). Students 
in more prestigious majors tend to have higher scores on entrance and exit exams (Waltenberg \& Carvalho, 2013). Another study demonstrated that students that entered public universities through quota systems were more likely to choose less selective majors (Dias Lopes, 2017).

Environmental variables. These include Blocks four (economic factors), five (social support), and six (individual involvement).

\section{RQ4: What influence do economic variables (after controlling for the above variables) have on performance on the overall ENADE score of quota-admitted students?}

In the previously mentioned studies on quota students, working vs. not working has been used as a control variable (Ribeiro, 2016; Valente \& Berry, 2017) and as an independent variable (Dias Lopes, 2017, Pedrosa et al., 2007). Working full time has been shown to negatively impact student retention (Astin, 1993); additionally, even working part-time before college had a negative impact on relative academic performance (Pedrosa et al., 2007). The effect on the retention of students' working parttime while attending college has shown mixed results in the U.S. (Wohlgemuth et al., 2006). Another study linked higher dropout rates among quota-admitted students who reported to be working (Cardoso, 2008). The reasons for selecting a particular institution, such as proximity to home, was included in Pedrosa et al., (2007)'s study but did not yield a significant result. Housing stipends and other forms of financial assistance were not considered in previous studies. Institutional scholarship or grants are positively associated with student retention (Astin, 1993). 


\section{RQ5 What influence do social support variables, inclusive of institutional and faculty support (after controlling for the above variables), have on the performance in the overall ENADE score of quota-admitted students?}

No study has examined the influence of social support networks on affirmativeaction Brazilian college students. In the U.S.-based literature, there is a positive relationship between perceived social support from parents, faculty, and peers and academic achievement. For example, Cutrona, Cole, Colangelo, Assouline, \& Russell (1994) found that perceived parental support from parents, friends, or romantic partners were predictors of academic performance in college students ( $N=418$ students, 234 women) at the University of Iowa. The social support parent scale used had an alpha coefficient of 0.81 . Support from parents significantly predicted grade point average when controlling for academic aptitude, family achievement orientation, and family conflict.

In a non-randomized study of college students in Argentina, de la Iglesia, Stover, and Liporace (2014) examined the relationship between perceived social support and academic achievement in ( $\mathrm{N}=760)$ (de la Iglesia et al., 2014). Women and men were examined in separate models because of the significant difference in the perceived levels of support. A regression model confirmed that for women, social support was a significant predictor of passed courses and classes dropped while not a significant predictor for failed courses (de la Iglesia et al., 2014). Social support was not a significant predictor for passed courses for men in this study though it was a small sample size $(\mathrm{N}=100)$. 
Esau Tovar (2014) further evaluated the influence of instructors' and counselors' support programs and their impact on the grade point average and intent to persist in a group of Latino/a student ( $\mathrm{N}=397)$ in community colleges in California. Tovar (2014) found a small but significant impact on students' intent to persist. Faculty interaction had a small but positive impact on GPA, with more interactions correlating with a higher GPA (Tovar, 2014). This study was conducted at a community college to test the validity of the College Mattering inventory, but no reliabile information was provided by the author. With social capital as the foundation, Tovar (2014) utilized Strayhorn (2006) and Crisp and Nora (2009) models of college student impact, which are inclusive of the factors contributing to first-generation and Hispanic students' success. This quantitative study applied ordinary least squares (OLS) regression for analysis. This model did not control for high school GPA, which is a strong covariate for college GPA (Astin, 1993).

In a qualitative study of ten Latino/a students in a large public mid-Atlantic research university, Hernandez (2000) wanted to understand what factors influenced students' retention and graduation, "and in what ways, if any, did the environment influence the experience and ultimately the retention?" (p. 576). The results found that, in no particular order, the following were important in retention for Latino/a students: determination, family support, friends and peers who acted as sources of support, faculty and staff who made a positive impact in their academic career, extracurricular involvement, finding a Latino community, finance matters, and making it work for yourself in a particular environment. Regarding social support, these findings are congruent with de la Iglesia et al. (2014) and Tovar (2014). It also touches on the 
challenges faced by Latino/a students, such as the university environment and the importance of finances. These are dicussed next.

In the U.S, university environment and social support have been shown to have a positive impact on Latino/a college students' retention (Gloria et al., 2005) and achievement (Hurtado, Clayton-Pedersen, Allen, \& Milem, 1998). Perceptions of prejudice against minority students can affect the academic experience. Conversely, positive racial climate is linked to success for minority students (Fischer, 2010).

Gloria, et al. (2005) studied ( $\mathrm{N}=99), 70 \%$ women, $71 \%$ of Mexican heritage in a majority White institution. Reliable and valid instruments were used, including university environment scale, cultural congruity scale, perception of barriers scale, college environmental stress index-modified, perceived social support inventory, parental encouraging scale, mentoring scale, Rosenberg self-esteem scale, college self-efficacy inventory, education degree behaviours, self-efficacy scale, and persistence/voluntary dropout decisions scale. Social support and university comfort were the strongest predictors of academic nonpersistence decisions (Gloria et al., 2005).

In a systematic review of 63 studies, Crisp et al. (2015) identified factors contributing to academic success of undergraduate Latino/a students. The factors most closely related with academic success for Latino/a students were (a) sociocultural characteristics, (b) academic self-confidence, (c) beliefs, ethnic/racial identity, and coping styles, (d) precollege educational experiences, (e) college experiences, (f) internal motivation and commitment, $(\mathrm{g})$ interactions with supportive individuals, (h) perceptions of the campus climate/environment, and (i) institutional type/characteristics (Crisp et al., 2015). 


\section{RQ6 What influence do individual involvement variables (after controlling for the above variables) have on performance in the overall ENADE score of quota- admitted students?}

Astin's 1975 study of dropouts demonstrated a positive relationship between environmental factors such as the number of hours spent studying; merit-based aid; majoring in education, humanities, and arts; and GPA (1993). None of these variables were used in previous studies examining the academic performance of quota-admitted students in Brazilian public universities. Speaking a foreign language has demonstrated a negative association with relative performance as per the observations of the study by Pedrosa et al. (2007). Alternatively, in the U.S., environmental factors such as studying abroad have shown a positive relationship after controlling for input (student personal characteristics including previous academic achievement) (Astin, 1993). The major selected and not the reason for choosing a particular major has been studied in relation to quota-admitted students. For example, students in selective majors tend not to be quotaadmitted students and tend to perform better academically than non-selective majors (Dias Lopes, 2017; Francis \& Tannuri-Pianto, 2012b; Waltenberg \& Carvalho, 2013).

Reading for pleasure during college has been found to be negatively associated with academic outcome (Astin, 1993). In the Brazilian context, it was not a significant variable though it was measured while in high school and not as a college environmental factor (Pedrosa et al., 2007). Astin concluded that these findings were aligned with the student involvement theory (Astin, 1984). He pointed out that extracurricular activities specifically related with faculty, fellow students, and academic work were positively related to retention while involvement with work, reading for pleasure, and living off 
campus were all negatively associated with retention because such commitments "take time and energy away from the academic experiences" (Astin, 1993, p. 197).

\section{Summary}

Chapter Two covered a broad spectrum of studies ranging from the first reactions to the unexpected top-down implementation quota-systems at state universities, followed by federally mandated affirmative-action policies in federal higher education institutions; academic performance of quota-admitted students as compared to non-quota; and the fascination of researchers in justifying quotas based on the notion that quota-admitted students can perform on par with non-quota students. It concluded with a targeted literature review of U.S. and Brazil-based students associated with each variable and block selected for the dissertation at hand. It was evident throughout the studies and historical context explored in this chapter that Brazilians' relationship with race is complicated. The decision to implement the Law of Social Quotas with a primary focus on socioeconomic status exemplifies the blurred racial context and the country's inability to unitedly recognize the existence of racism within Brazil and its role in the improvised schooling outcomes for Browns and Blacks, which comprise more than half of the population.

In light of the aggregate relative academic success achieved by quota-admitted students described in this chapter, with notable exceptions in hard sciences and what many have deemed "high prestige" majors, a study designed to identify the factors that contribute to quota-students' success is required. Chapter Three addresses the research design, the dependent and independent variables, and other aspects of the methodology for the present study. 


\section{Chapter Three Methods}

\section{Theoretical Framework}

Two theoretical frameworks guided the study - the social support theory (Malecki \& Demaray, 2006; Tardy, 1985) and Astin's student involvement theory (1984), specifically the input-environment-outcome model (I-E-O) (Astin, 1993). However, since this study is set in Brazil, merely borrowing US-based retention and achievement theories would be inappropriate for the study. Instead, I opted to understand from which perspectives the academic achievements of the lower socioeconomic class in Brazilian universities have been previously studied. I focused on the studies conducted before the implementation of the national affirmative-action law in higher education to understand the socio-cultural challenges and barriers students from the less economically advantaged households faced in Brazil to inform the variables of this dissertation. Informing the selection of the framework for this dissertation are the Brazilian works of Viana (1998) and Portes (2001), which subsequently build on the works of the French sociologists Laurens (1992) ${ }^{17}$ and Lahire (1997). ${ }^{18}$

Astin (1999) found and many others have affirmed that within the United States, students' connections to the campus, including living on campus, spending time on extracurricular activities, meeting with faculty, and participating in student organizations are

\footnotetext{
${ }^{17}$ For a detailed description of the study see Lahire, B. (1997). Sucesso escolar nos meios populares: as razões do improvável. São Paulo: Ática.

${ }^{18}$ For a detailed description of the study see Laurens, J.P. (1992). 1 sur 500: la reussite scolaire en milieu populaire. Toulouse: Presses Universitaires du Mirail.
} 
positively related to their retention. He understood these connections as indications of involvement that he defined as "the amount of physical and psychological energy the student devotes to the academic experience" (Astin, 1999, p. 518). Similarly, Portes' (2001) descriptions of the experiences of students at the Federal University of Minas Gerais reveal that Brazilian students felt more at ease and adapted to the university after connecting with other students or staff through research centres, on-campus employment, or by spending more time in the shared common area (such as cafeterias). To predict retention and to operationalize the conditions related to involvement, Astin created the input-environment-outcome (I-E-O) model where students' background characteristics (input) and the institutional environment (environment) are said to be related to, and possibly predictive of, student retention (the output in question). This study borrows Astin's I-E-O model to investigate the academic performance of students in Brazil (see Figure 2).

\section{Framework Justification}

Astin's I-E-O model was adopted as the framework since its adaptability and flexibility are favorable for this study given the differences in culture, history, and background between the population the framework was created for and stud's sample.

The I-E-O framework has three general categories of variables. The first section, called inputs, refers to the characteristics or abilities of students at the time of entry to the institution that are known to have an effect or impact on the outcome measured. The input category is necessary to account for pre-existing abilities or factors that have a direct or indirect impact on the measured outcome (Astin, 1993). The environmental variables refer to the programs, people, and various aspects of the college life that 
students are exposed to. Outcome variables are what the students gain after exposure to the environmental variables while controlling for the input.

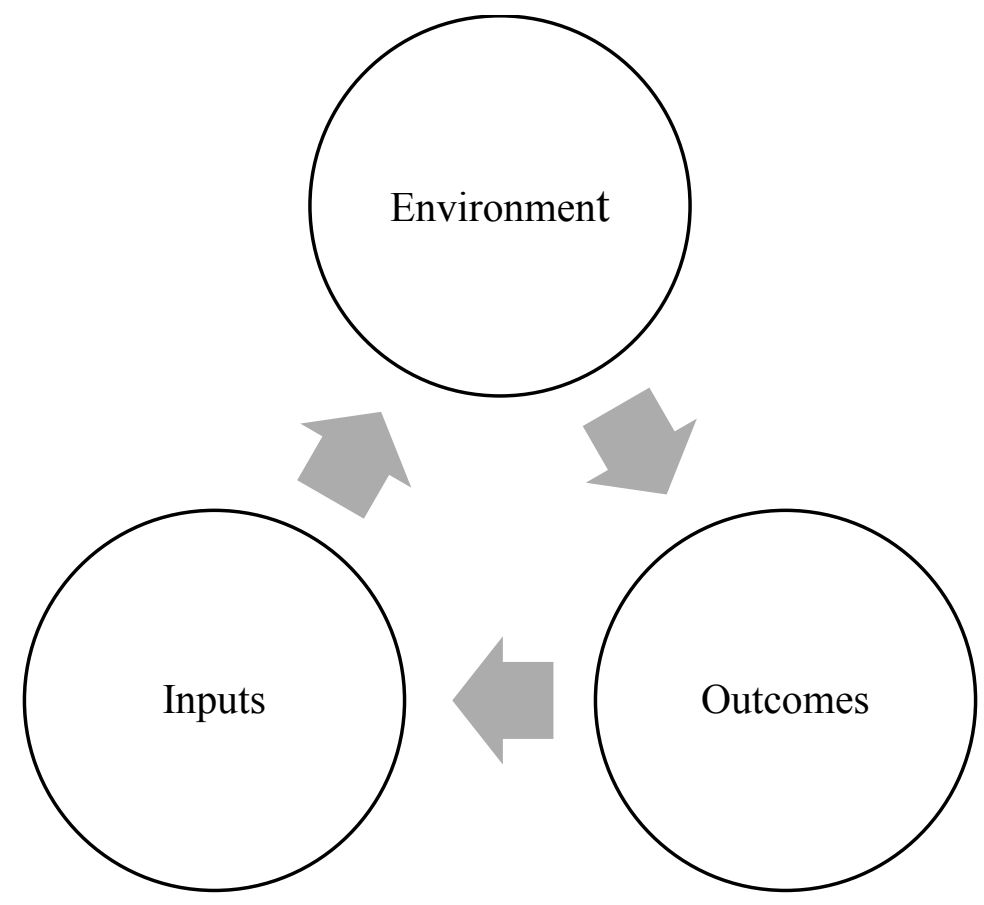

Figure 2. Astin's Input-Environment-Outcomes (I-E-O) Model (1993).

Note. Image created by the author based on information found in Astin (1993).

In applying this model to this study, the variables are grouped in the following way:

- Input variables - Personal characteristics, family factors, secondary school variables, and pre-college variables.

- Environmental variables - Social support variables, economic factors, and individual student involvement variables.

- Outcome variables - ENADE College Exit Exam score. 


\section{Conceptual Framework}

Using Astin's I-E-O model as the framework, this study employed the following set of variables to serve as inputs-environment-outcome. The variables were assigned to blocks that correspond to the inputs, environment, and outcome groupings in the I-E-O model as presented in Table 3 and were derived from the literature on both higher education retention and academic achievement in the United States and Brazil. Table 3 illustrates the operationalization of the conceptual framework applied in this study.

\section{Research Design}

The study used a correlational research design to determine to what extend these factors explained student success among quota students in Brazil. A hierarchical linear regression technique was employed to analyse the data. According to Creswell (2005), prediction correlational research designs are used for studies where the prediction criterion variables and the predictor variables are not collected simultaneously. A hierarchical linear regression analysis can determine the added variance in each model that is explained by the addition of each block. Given that this study used a census of the population, inferential statistics that aim to speak of a population based on a sample were not necessary. However, given the ubiquity of reporting p-values in both non-census and census-based studies in the field of higher education, p-values are reported using the most conservative common estimate at $\mathrm{p} \leq .001$. 
Table 3. I-E-O Utilized Model in the Study

\begin{tabular}{|c|c|c|}
\hline Inputs & Environment & \\
\hline $\begin{array}{l}\text { Block 1- Personal and } \\
\text { family characteristics }\end{array}$ & $\begin{array}{l}\text { Block 3- Pre-college } \\
\text { variables }\end{array}$ & $\begin{array}{l}\text { Block 5- Social, } \\
\text { institutional, and faculty } \\
\underline{\text { support }}\end{array}$ \\
\hline Age & Evening student & Social support \\
\hline Sex & Living arrangement & Institutional/Faculty support \\
\hline Race & Type of affirmative-action & $\begin{array}{l}\text { Block 6- Individual student } \\
\underline{\text { involvement }}\end{array}$ \\
\hline $\begin{array}{l}\text { Mother's educational } \\
\text { level }\end{array}$ & STEM vs. Non-STEM major & $\begin{array}{l}\text { Number of hours spent } \\
\text { studying }\end{array}$ \\
\hline $\begin{array}{l}\text { Father's educational } \\
\text { level }\end{array}$ & Reason for major selection & Reading for pleasure \\
\hline Family income & $\begin{array}{l}\text { Selected university because } \\
\text { of high reputation }\end{array}$ & $\begin{array}{l}\text { Opportunity to learn a foreign } \\
\text { language }\end{array}$ \\
\hline $\begin{array}{l}\text { Block 2- High school } \\
\underline{\text { variables }}\end{array}$ & Highly selective university & \\
\hline $\begin{array}{l}\text { High school geo. } \\
\text { location }\end{array}$ & Block 4- Economic factors & Outcome \\
\hline $\begin{array}{l}\text { High school type } \\
\text { (public vs. private) }\end{array}$ & $\begin{array}{l}\text { Contributed to family } \\
\text { finances }\end{array}$ & $\begin{array}{l}\text { ENADE general knowledge } \\
\text { exam }\end{array}$ \\
\hline \multirow{4}{*}{$\begin{array}{l}\text { High school traditional } \\
\text { vs. non-traditional }\end{array}$} & Worked during college & \\
\hline & Scholarship recipient & \\
\hline & $\begin{array}{l}\text { Received need-based } \\
\text { retention services }\end{array}$ & \\
\hline & $\begin{array}{l}\text { Academic Involvement } \\
\text { scholarship }\end{array}$ & \\
\hline
\end{tabular}


As discussed in Chapters 1 and 2, this study seeks to identify factors that influence affirmative-action students' achievement in Brazilian federal universities. It follows an overarching research question and six sub questions:

1. What is the overall explanatory power of the full model? In other words, after including all of the variables (i.e., characteristics and family demographics, high school variables, pre-college variables, economic variables, social support variables, and individual involvement variables), how effectively does the model explain the performance of quota-admitted students' performance in the ENADE exam?

The six sub questions are:

1. What influence do entering students' characteristics and family demographics have on performance in the overall ENADE score of quota-admitted students?

2. What influence do high school variables have on performance on the overall ENADE score of quota-admitted students?

3. What influence do pre-college variables have on performance on the overall ENADE score of quota-admitted students?

4. What influence do economic variables (after controlling for the above variables) have on performance on the overall ENADE score of quota-admitted students?

5. What influence do social support variables inclusive of institutional and faculty support (after controlling for the above variables) have on performance on the overall ENADE score of quota-admitted students? 
6. What influence do individual involvement variables (after controlling for the above variables) have on performance on the overall ENADE score of quotaadmitted students?

The dependent variable in this study is the score on college exit exam score, that is used as a representation of the students' achievement as measured by the (Brazilian) Ministry of Education since 2004 (Instituto Nacional de Estudos e Pesquisas Educacionais Anísio Teixeira (INEP), 2015). Previous studies have used this exam as a proxy to measure student achievement (Valente \& Berry, 2017; Waltenberg \& Carvalho, 2013). A student survey (socioeconomic questionnaire) administered before the ENADE exam (college exit exam) is mandatory for all the participating students. The Ministry of Education uses the ENADE exam is used to evaluate the Brazilian higher education system. Each year, the Brazilian Ministry of Education uses the ENADE exam as a proxy for the evaluation of different undergraduate programs.

The independent variables included in this study were derived from the survey, which has been used since 2004. Social support networks, economic factor variables, and institutional context were included as independent environmental variables as part of Astin's (1993) I-E-O model. After reviewing the literature, these variables were chosen on the basis of their influence on achievement and the retention of students' college outcome (Astin, 1993; Tinto, 1975).

The input variables are what the students bring with them to the institutions and have been shown to influence output or environment. The input variables for this study are personal variables (age, gender, race), family variables (parents' education, family income), and educational variables (secondary school type[private vs. public]and 
location). The environmental variables are pre-college block (academic scholarship, study habits, time of attendance [evening vs. daytime], selection of institution [proximity to home vs. other], and major [labor market/social prestige vs. other]). The pre-college variables block can be both an input and environmental variable since the impact or characteristic is harder to define, and as such Astin (1993) described this block as "InputEnvironment Bridge."

Tables 4 and 5 delineate the variables and their respective components using Astin's I-E-O model in the context of this present study. On the left most column is the block followed by the items or variables, and the last column includes the coding scheme used in the study. Table 4 references the dependent variable, while Table 5 provides detailed information on the independent variables.

Table 4. Dependent Variable

\begin{tabular}{llll}
\hline Variable & Item & Original & Coding \\
\hline Outcome & $\begin{array}{l}\text { College exit exam } \\
\text { (ENADE) }\end{array}$ & Score 0 to 100 & $\begin{array}{l}\text { Low (0) to high } \\
(100)\end{array}$ \\
& $\begin{array}{l}\text { Part I General knowledge } \\
\text { Table 5. Independent Variables }\end{array}$ & &
\end{tabular}

\begin{tabular}{|c|c|c|}
\hline Block & Items & Coding scheme \\
\hline $\begin{array}{l}\text { 1- Personal } \\
\text { characteristics } \\
\text { and family } \\
\text { factors }\end{array}$ & $\begin{array}{l}\text { Age } \\
\text { Sex } \\
\text { Race } \\
\text { Mother's educational level } \\
\text { Father's educational level } \\
\text { Family income }\end{array}$ & $\begin{array}{l}\text { Continuous } \\
1 \text { female; } 0 \text { male } \\
1 \text { Non-White; } 0 \text { White } \\
0 \text { No schooling through; } 5 \\
\text { Attended Graduate school } \\
0 \text { No schooling through; } 5 \\
\text { Attended Graduate school } \\
0 \text { (low) to } 5 \text { (high) }\end{array}$ \\
\hline $\begin{array}{l}\text { 2- High school } \\
\text { variables }\end{array}$ & $\begin{array}{l}\text { High school location } \\
\text { High school type } \\
\text { High school type of courses }\end{array}$ & $\begin{array}{l}\text { SP, RJ, MG, ES; } 1 \text { Yes; } 0 \text { No } \\
1 \text { Public; } 0 \text { Private } \\
1 \text { Traditional high school; } 0 \text { Not }\end{array}$ \\
\hline
\end{tabular}




\begin{tabular}{|c|c|c|}
\hline $\begin{array}{l}\text { 3- Pre-college } \\
\text { variables }\end{array}$ & $\begin{array}{l}\text { Time of attendance } \\
\text { Living on campus } \\
\text { Type of affirmative-action } \\
\text { STEM vs. Non-STEM } \\
\text { Selected major due to prestige or } \\
\text { labour market } \\
\text { Reason for choosing this } \\
\text { university? } \\
\text { Highly selective university } \\
\end{array}$ & $\begin{array}{l}1 \text { Yes (Evening); } 0 \text { No } \\
1 \text { On campus; 0 Not } \\
1 \text { Disability/Lowest SES; 0 All } \\
\text { other types } \\
1 \text { STEM; 0 Non-STEM } \\
1 \text { A \& D (labor market or social } \\
\text { prestige); All other answers } \\
\text { 0 Yes, Proximity to home; } 0 \text { No } \\
1 \text { Highly selective; 0 All others }\end{array}$ \\
\hline $\begin{array}{l}\text { 4- Economic } \\
\text { factors }\end{array}$ & $\begin{array}{l}\text { Contributed to family finances } \\
\text { Working status } \\
\text { Received scholarship } \\
\text { Retention services (food, } \\
\text { lodging or meal stipend, or } \\
\text { combination) } \\
\text { Academic involvement } \\
\text { scholarship }\end{array}$ & $\begin{array}{l}1 \text { Yes; } 0 \text { No } \\
1 \text { Yes; } 0 \text { No } \\
1 \text { Yes; } 0 \text { No } \\
1 \text { Yes; } 0 \text { No } \\
1 \text { Yes; } 0 \text { No }\end{array}$ \\
\hline \multirow{3}{*}{$\begin{array}{l}\text { 5- Social, } \\
\text { institutional, } \\
\text { and faculty } \\
\text { support }\end{array}$} & Social support & 1 Yes; 0 No \\
\hline & $\begin{array}{l}\text { Social support } \\
\text { Have any of the groups below } \\
\text { been decisive for you to face } \\
\text { difficulties during your college } \\
\text { course and complete it? }\end{array}$ & $\begin{array}{l}1 \text { Received support while facing } \\
\text { challenges; } 0 \text { All other responses }\end{array}$ \\
\hline & $\begin{array}{l}\text { Institutional/Faculty Support } \\
\text { (1-6 scale, Strongly disagree- } 1 \text {, } \\
\text { Strongly agree-6) }\end{array}$ & $\begin{array}{l}\text { (see Appendix A for scales and } \\
\text { items) } \\
\text { i.e. Faculty-student relationships } \\
\text { throughout the course stimulated } \\
\text { you to study and learn. }\end{array}$ \\
\hline $\begin{array}{l}\text { 6- Individual } \\
\text { involvement }\end{array}$ & $\begin{array}{l}\text { Number of hours spent studying } \\
\text { Reading for pleasure } \\
\text { Opportunity to learn a foreign } \\
\text { language }\end{array}$ & $\begin{array}{l}\text { (0) None to (5) to }+12 \text { hours } \\
\text { (0) None to (5) to }+8 \text { books } \\
1 \text { Yes; } 0 \text { No }\end{array}$ \\
\hline
\end{tabular}

\section{Participants}

The participants in the study were graduating university students selected to take the ENADE exam (college exit exam) in 2016 and who had completed the socioeconomic questionnaire ( $N=195,463)$. All students earning a bachelor's degree from federal universities were included in the initial sampling frame $(N=27,388)$. However, only students who are quota-admitted were included in this study $(\mathrm{N}=6,908)$. There was 
$8.8 \%$ missing data. Four variables accounted for all the missing data, the average institutional and faculty support, the total ENADE score, race, and high school location. In almost all the cases, the researcher chose not to manipulate the missing values and opted for listwise deletion. After cleaning up the data by removing the missing values, the final number of participants is $\mathrm{N}=6,557$, with $66.7 \%$ female and $58.2 \%$ non-White participants. The dataset includes the entire population of students in the selected majors and met the selection criteria for 2016 .

All students in the selected majors (agronomy, biomedicine, physical education, nursing pharmacy, physiotherapy, speech therapy, medicine ${ }^{19}$, veterinary ${ }^{20}$, nutrition, dentistry, ${ }^{21}$, social work, zootechnics ${ }^{22}$ ) in their first and final years of the program evaluated completed the test. This study is limited to federal public university students who are graduating (last semester) and finished the socioeconomic questionnaire.

\section{Design}

This study utilized a correlational approach with a predictive design. A randomized experiment was not an option for this study because of the number of variables explored that included innate and family characteristics that cannot be assigned by the researcher (e.g., income, race, gender, major, high school location, attending public vs. private high schools, etc.); resultantly, a correlational approach is best suited

\footnotetext{
${ }^{19}$ Medicine is an undergraduate degree program in Brazil.

${ }^{20}$ Veterinary medicine is an undergraduate program in Brazil.

${ }^{21}$ Dentistry is an undergraduate program in Brazil.

${ }^{22}$ Zootechnics refers to the science related to production, breeding, treatment, domestication or handling of animals.
} 
for this type of study. A hierarchical linear regression, a method of ordinary least squares (OLS) regression, was performed to answer each of the research questions. This study focused on the student-level and while there were variables about the institution-level, hierarchical linear modeling (HLM) was not used to assess the cross-level effect. Astin and Denson (2009) conducted an analysis using HLM or OLS regression in multicampuses to determine the method that would be a better fit. They concluded that when following a specific set of criteria, there was no difference in the model fit between HLM and OLS (Astin \& Denson, 2009).

The three steps in conducting a hierarchical linear regression were the following:

(1) Block variables based on the sequence in which they occurred,

(2) Add each variable based on the theoretical predictive power, and

(3) Use the "Beta in" feature to see what the added predictive value would be of the "not yet" added variable in the step.

While answering questions about performance more broadly and without incorporating environmental variables, Waltenberg and Carvalho (2013) and Valente and Berry (2017) used a correlational approach and the OLS method to determine the academic performance of quota and non-quota admitted students; however, the methodology is not elaborated and it is unclear whether the hierarchical linear regression technique was adopted. Valente and Berry (2017) adjusted the standard errors using vce (robust) to mitigate possible errors of not using HLM in their study.

In summary, the hierarchical linear regression allows the researchers to use a theoretical framework to guide the order in which the variables are added to the model while controlling for the known covariates. This technique enables the researcher to 
examine the relationship between environmental variables (programs or experiences in college) and outcomes (student learning) while controlling for inputs (student and family demographics, previous abilities, etc.); this is known as the net effect (Volgt, 1999, as cited by Strayhorn \& Johnson, 2014).

Volgt (1999) described hierarchical regression as:

... a method of regression analysis in which independent variables are entered into the regression equation in a sequence specified by the researcher in advance. The hierarchy (order of the variables) is determined by the researcher's theoretical understanding of the relations among the variables. (as cited by Strayhorn \& Johnson, 2014, p. 542)

Data collection procedures. The Ministry of Education in Brazil collected the data. The variables used in the study are available in the public data-set. ${ }^{23}$ The socioeconomic questionnaire is completed online before students take the in-person exam. Using the Statistical Package for Social Sciences (SPSS), statistical analysis and descriptive statistics are used to answer each of the research questions. The analysis is organized in the sequence of the research questions, starting with the results of the broader issue and then narrowed down to each of the six sub-questions.

Procedure. All variables were recoded according to the descriptions in Table 2 and in the text above. For this study, the variables are continuous or dichotomous. Since this is a correlational study, there are no treatments. Instead, the study engaged Astin's (1993) three-step recommendation for using OLS in an educational correlational setting

\footnotetext{
${ }^{23}$ available for download at http://inep.gov.br/microdados
} 
to establish a correlational relationship between environment and outcome by accounting or controlling for input characteristics (the abilities students possess before entering college). The variables are grouped into blocks and each block is analyzed for its added explanatory power, thereby allowing the researcher to evaluate the added benefit for the subsequent blocks while controlling for the previous blocks' explanatory power. This model is useful in educational research where it is not feasible to develop an experimental or quasi-experimental design to test a hypothesis.

Clean and account for missing data. With a large dataset, Creswell (2005) recommends using frequency distribution for each variable to ensure that the responses are within the expected range. For example, if in a male or female value a " 3 " is present, we can assume that an error has occurred since the range of responses is " 0 " or " 1 ". A frequency table was used to analyze and determine the percentage of missing data. The original population was $\mathrm{N}=7,215$; however, as shown in Table 7, there were cases with some variables missing consisting of $8.8 \%$ of the population. The researcher used the listwise deletion method for most variables with special treatment used in average institutional faculty and institutional support variable. Similarly, the deletion technique deletes a case if any of the variables are missing. This is the most common method for dealing with missing data (Peng, Harwell, Liou, Ehman, \& others, 2006).

One variable within the Institutional and Faculty Support Block (Block number 5) comprised of seven items, each ranging in response from 1 to 6 . If one item is missing, SPSS substituted the average of the other six items in a technique called mean substitution. There are general guidelines regarding the acceptable missing data. Enders (2003) found "that a missing rate of $15 \%$ to $20 \%$ was common in educational and 
psychological studies" (as cited in Dong \& Peng, 2013, p. 1). According to Bennett (2001), anything above $10 \%$ might create biased results. Given previous guidance, the $8.8 \%$ missing data rate is therefore acceptable. As illustrated in Table 7, four variables accounted for all of the missing data, the average institutional and faculty support, the total ENADE score, race, and high school location. In almost all cases, the researcher chose not to manipulate the missing values and opted for listwise deletion.

Table 6. Missing Data Analysis

\begin{tabular}{|c|c|c|c|c|c|c|c|}
\hline \multirow[b]{2}{*}{ Variable } & \multirow[b]{2}{*}{$\mathbf{N}$} & \multirow[b]{2}{*}{ Mean } & \multirow{2}{*}{$\begin{array}{l}\text { Std. } \\
\text { deviation }\end{array}$} & \multicolumn{2}{|c|}{ Missing } & \multicolumn{2}{|c|}{ No. of extremes } \\
\hline & & & & Count & Percent & Low & High \\
\hline $\begin{array}{l}\text { Avg institutional } \\
\text { support }\end{array}$ & 7,055 & 4.6533 & 0.96847 & 160 & 2.2 & 56 & 0 \\
\hline Total ENADE score & 6,941 & 56.0192 & 13.79364 & 274 & 3.8 & 81 & 0 \\
\hline Race & 7,027 & & & 188 & 2.6 & & \\
\hline High school location & 7,175 & & & 40 & .6 & & \\
\hline
\end{tabular}

Multicollinearity and statistical regression assumptions. To address

multicollinearity before the analysis, the researcher investigated the existence of highly intercorrelated $(\mathrm{r}=0.7)$ predictors using a correlation matrix of all the predictors in the regression model. There were no variables with intercorrelation exceeding the 0.7 guideline. A complete table can be produced upon request. The researcher verified that the assumptions of the regression model, such as errors having a constant variance, the independence, and the data that is normally distributed, were met before interpreting the findings.

There was linearity between the independent and dependent variables, as assessed by a plot of studentized residuals against the predicted values. Independence of residual was observed as evaluated by a Durbin-Watson statistic of 1.813 . Homoscedasticity, as 
assessed by a visual inspection of the plot of studentized residuals versus unstandardized predicted values was also observed. No evidence of multicollinearity was recorded as indicated by tolerance values greater than 0.1 . There were no leverage values greater than 0.2 and no values for Cook's distance above 1 . There were some studentized deleted residuals greater than \pm 3 standard deviations. The researcher removed these values and re-ran the model, and these outliers did not have an impact on the results. Therefore, they were added back into the model. Their assumption of normality was met as assessed by the Q-Q plot.

\section{Instruments and Data}

The ENADE total score is the sole dependent variable measuring the academic performance of students (measured from 0 to 100). This information is collected and made publicly available by the Brazilian Ministry of Education. This exam has been used for 12 years to measure student achievement. No information on the validity or reliability of this instrument is available.

There is a significant amount of debate regarding the validity and predictability of variables measured by one item (Diamantopoulos, Sarstedt, Fuchs, Wilczynski, \& Kaiser, 2012). Diamantopoulos et al. (2012) argue that multi-item scales are better than single item scales in most scenarios, while Bergkvist and Rossiter (2007) support the concept of a single item when it "is a doubly concrete construct" (p. 183). Additionally, Bergkvist and Rossiter claim that as per the observations of their study, single items can be "generalized to other concrete attributes, such as beliefs or perceptions, intentions and satisfaction" (p. 183). For this study, most of the variables are concrete constructs, such 
as During your schooling, did you receive any academic scholarships? ${ }^{24}$ With the exception of the social support scale, which combined seven Likert scale-like questions, none of the other questions measured abstract ideas or feelings but evaluated concrete attributes. Therefore, as shown in Table 3, most of the variables in this study are measured through only one corresponding questionnaire entry (except for the social support scale created from seven Likert scale-like questions. $)^{25}$

\section{Independent variables: Input blocks 1-2: Characteristics and high school variables.}

The variables in this section are broken down into two blocks.

Block 1: Personal characteristics and family factors. The personal characteristics variables are age (measured as a continuous variable) and sex (coded using a dummy variable whereby male is coded as " 0 " and female as " 1 "). Students chose from the following categories for race/ethnicity (a) White, (b) Black, (c) Asian/Yellow, (d) Brown, (e) Indigenous, or (f) Prefer not to disclose. The IBGE (equivalent to the U.S. census) uses five race/ethnic-based categorizations, including Yellow for Asians and Brown for mixed-race individuals; both of which may seem offensive to non-Brazilians. This study does not seek to engage in a debate about the political correctness of such categorization, but it is important to note that Brown (pardo) is not a pejorative term in Brazil. For the purposes of this study, a dummy variable for the race White was coded as " 0 " and nonWhite (encompassing all other race/ethnicities) was coded as "1".

\footnotetext{
${ }^{24}$ See Appendix D for a complete coding scheme, including all questions translated by author.

${ }^{25}$ See Appendix A for full information on scale development.
} 
Three variables measured family factors - (1) mother's educational level, (2) father's educational level, and (3) family income. Students reported the educational levels of their parents from among the following options: (a) none, (b) elementary school, (c) middle school, (d) high school, (e) undergraduate, and (f) graduate. This is an ordinal variable; for this study, it was recoded as a continuous variable with " 0 " representing no schooling and " 5 " indicating having completed graduate studies, as has been followed by Valente and Berry (2017). ${ }^{26}$ Students reported family income among the following options: (a) up to 1.5 times the minimum salary (MS), (b) from 1.5 to $3 \mathrm{MS}$, (c) from 3 to 4.5 MS, (d) from 4.5 to $6 \mathrm{MS}$, (e) from 6 to $10 \mathrm{MS}$, (f) from 10 to $30 \mathrm{MS}$, and (g) above 30 MS. ${ }^{27}$ According to the 1988 Brazilian constitution, the minimum wage/salary should cover the basic necessities for the worker and their family (food, housing, education, and leisure expenses) (“Salário Mínimo [Minimum wage],” 2018). This variable was recoded from 0 representing "up to $1.5 \mathrm{MS}$ " to 6 representing "above $30 \mathrm{MS}$ ". This measure will be interpreted as continuous; however, the researcher understands that this is not measured at equal intervals as would be optimal for such a conversion. Using the same data set, Valente and Berry (2017) also used a similar categorization to measure family income.

Block 2: High school variables. Students selected from 28 options regarding the location of the high school attended; these included all 26 states, federal district, and the

\footnotetext{
${ }^{26}$ In this case, it appears that undergraduate education is inclusive of associates degrees; the survey does not make a distinction.

${ }^{27}$ Salaries in Brazil are reported in monthly and not annual amounts. Minimum wage is set by the government.
} 
"did not apply" option. Regional differences are observed in literacy rates, racial makeup, economic outcomes, and attainment of education ("Economia do Sudeste [Southeast's economy]", n.d.). Resultantly, a variable was created to account or control for the high school location. For comparative purposes, the country is divided into five sections North, Northeast, Central-west, Southeast, and South. The Southeast states are SP, RJ, MG, ES, and together this region constitutes more than half of the country's gross domestic product (GPD) and is the most densely populated ("Economia do Sudeste [Southeast's economy]," n.d.). High schools in the Southeast region were coded "1", and all other regions were assigned "0". Students could choose from four different responses on the high school type; the codes used were "1" for public and "0" for private school. Students' responses on the type of courses completed in high school were grouped into traditional courses coded as " 1 " and non-traditional coded as " 0 ".

Independent variables: Environment block 3: Pre-college variables. College students' time of attendance was coded as " 1 " for night/evening and all others coded as “0”. Students' primary reason for major selection such as prestige or profits were coded as "1" and other reasons coded " 0 ". In Brazil, previous studies have linked more profitable majors with students from more privileged backgrounds (Dias Lopes, 2017; Francis \& Tannuri-Pianto, 2012a) Students' residential arrangements were grouped into living on campus and coded "1", and other arrangements (i.e., in a house or apartment alone; with parents; with spouse and children; in an off-campus location with other college students, and; other ) were coded as "0". Astin (1993) found a positive relationship between living on campus and academic success. Students chose from the following types of affirmative-action admission: (a) none, (b) yes, based on 
race/ethnicity, (c) yes, based on socioeconomic status, (d) yes, based on public high school attendance, (e) yes, a combination (f) yes, other. For the purposes of this study, only students who entered through quota were included, i.e., answers b-f. Students who selected socioeconomic status and the disability quotas were coded as " 1 " and all other types as “0”. Valente and Berry's (2017) study demonstrated that these two categories scored significantly lower than non-quota students even when controlling for some factors. Students chose from the following responses regarding why they chose this institution: (a) free tuition, (b) cost of tuition, (c) proximity to home, (d) proximity to work, (e) accessibility, (f) prestige, (g) only one I was accepted into, (h) scholarships, and (i) other reasons. The proximity to the home variable was coded "1"; all other answers were coded "0".

Students' majors were coded into two categories to account for the variability of scores caused by caused by differences in majors selected. Previous studies have demonstrated that some majors score significantly higher on the ENADE exam or the entrance exam compared to other majors (Bezzera, 2010; Dias Lopes, 2017; Waltenberg \& Carvalho, 2013). STEM majors were coded with a value of "1", and non-STEM majors were assigned a value of " 0 ".

Block three is the bridge block, which can be perceived as both environmental and input variables; for example, living arrangements. If you live on campus, your environment changes and can subsequently influence your outcome. Block three is comprised of variables that occur during the college years but are selected before starting college. Such variables are considered to be bridge variables because it is difficult to determine if they are to be considered an input or as part of the environment. As a result 
of the potential duality of interpretation, this group of variables are referred to as the bridge block. This includes: type of enrollment (evening student), living armament, type of affirmative-action, STEM vs non-STEM major, reason for major selection, and type of institution (selective vs non-selective). While these choices are made prior to enrolling in college, they can influence the outcome (academic success) or other environmental variables that in turn have an impact on the outcome. To account for this impact, the bridge variables are intentionally placed immediately after the inputs but before the environmental blocks.

Block 3 also included the university selectivity variable, which is designed to control for the institutional differences among the experiences of students betweencolleges. Astin (1993) suggests controlling for institutional selectivity, location, faculty, and student peer group. This study focuses only on federal universities in Brazil, which are generally selective and tuition free. The university selectivity variable is derived for the Índice Geral de Cursos [Course Evaluation Index] developed by the Ministry of Education in Brazil. This indicator ${ }^{28}$ assesses the quality of higher education institutions on a scale of 1 to 5 with 5 being the highest quality (Instituto Nacional de Estudos e Pesquisas [National Institute of Studies and Research], 2017). Apart from controlling for institutional selectively, this study does not attempt to control for differences between peer groups or faculty. In 2016, as depicted in Table $6,18 \%$ of the federal universities earned 3 points, a majority $66 \%$ earned 4 points, and $16 \%$ institutions came the highest

\footnotetext{
${ }^{28}$ For a detailed explanation of the calculation of the index see this Technical Note, http://download.inep.gov.br/educacao_superior/enade/notas_tecnicas/2017/nota_tecnica_n19_2018_igc201 7.pdf
} 
with 5 points. Universities were deemed highly-selective if they had a course evaluation index of 5; the variable is coded " 1 " and all other values are denoted with " 0 ".

Table 7. Course Evaluation Index Breakdown for Federal Universities 2016

\begin{tabular}{|l|r|r|r|r|c|}
\hline Ranking & $\mathbf{1}$ & $\mathbf{2}$ & $\mathbf{3}$ & $\mathbf{4}$ & $\mathbf{5}$ \\
\hline Percentage & 0 & 0 & $18 \%$ & $66 \%$ & $16 \%$ \\
& & & & & \\
\hline
\end{tabular}

Note: Table was arranged by author with information from Instituto Nacional de Estudos e Pesquisas [National Institute of Studies and Research] (2017).

\section{Independent variables: Environment block 4: Economic factors.}

Block 4: Economic factors. The economic factor variables comprise of five questions. Students were grouped into family finances (income); contributors coded value of "1" and non-contributors coded value " 0 ". Students were grouped into two groups depending on their responses regarding work. Students who worked were coded with a value of " 1 ", and students not working were coded as " 0 ". ${ }^{29}$ There were two separate questions about scholarships - one related to academics and involvement during college and the other focused more on merit. Students who were awarded an academic scholarship before college were coded with a value of "1", and students who received no academic scholarship were coded with a value of " 0 " corresponding with the received scholarship variable. On the academic involvement scholarship variable, students' responses regarding academic involvement scholarship during college were coded as values " 1 " and " 0 " for all the others. This type of scholarship included working in a lab, working as a teaching assistant, and being engaged in community program coordination

\footnotetext{
${ }^{29}$ Included working part-time and full-time.
} 
and research. Students were grouped into those who received aid, coded with a value of " 1 " and those who did not receive financial aid, coded with a value of " 0 " based on their responses about receiving need-based retention services. It is assumed that students' selfreporting is accurate and valid.

\section{Independent variables: Environment block 5: Social, institutional, and faculty support.}

Social support. The social support variable comprises of two questions. Students chose from the following options regarding the strongest agent of encouragement to attend college: (a) no one, (b) parents, (c) other family members, (d) faculty members, (d) religious leader, (f) friends or classmates, and (g) others. This variable was recoded into received support with a coded value of "1" and no support coded value "0". Students were asked which groups, if any, provided support during a difficult time in their college studies; they chose from the following options: (a) did not have difficulties, (b) did not receive support, and options (c-k) specified various groups. This social support variable was recoded into one variable with two groups. If a student answered "parents" or any other group as per answers c-k, it was recoded as "received support" with a coded value of "1". Other answers were coded as " 0 ".

Institutional and faculty support. The institutional and faculty support variable comprised of seven items (each rated on a 1-6 scale - from strongly disagree to strongly agree); see Appendix A. Some examples of the questions are "The coursework required constant dedication and effort to meet academic standards" and "The university employs sufficient tutors to meet your needs." Students' responses ranged from 1 to 6 (1=strongly disagree and $6=$ strongly agree). The seven questions related to institutional and faculty 
support were factor-analyzed using principal component analysis (PCA) with Direct Oblimin rotation. The analysis yielded one factor explaining a total of $52.76 \%$ of the variance for the entire set of variables. The communalities extraction values of the variables ranged between .472 and .584 . These values can be interpreted as effect sizes and for items in a scale, values above $<.3$ contribute significantly. Additionally, the Kaiser-Meyer-Olkin measure of sampling adequacy and Bartlett's test of sphericity both indicate that these set of variables are adequately related for factor analysis.

As a result of the PCA, all seven items were combined into a continuous variable. Using SPSS, the researcher performed a scale reliability analysis for all the seven items combined to measure the scale's internal consistency. The results range from 0 to 1 , with 1 being complete consistency and 0 being no consistency. A value above 0.7 is generally regarded as a reliable scale (Field, 2009). The institutional and faculty support variable had an internal consistency as measured by Cronbach's alpha of 0.848 , making it a reliable scale.

A mean composite score of the seven items was used to create a continuous variable. These questions are typically used to assess the success of the undergraduate program at the institutional level. Thus, students from each university and specific majors are grouped to evaluate the individual program. For this study, the focus is on the studentlevel.

\section{Independent variables: Environment block 6: Individual involvement.}

Individual involvement. These variables were built from three questions. Students chose from the following options regarding weekly hours spent studying: (a) none, (b) between 1 and 3, (c) between 4 to 7, (d) between 8 to12, and (e) more than 12. This 
variable was coded from low that was coded as " 0 " to high that was coded as "4", representing a continuous variable.

The reading for pleasure variable queried the number of books read over the last year. The options ranged from from (a) zero, (b) 1 to 2 books, (c) 3 to 5 books, (d) 7 to 8 books, (e) more than 8 books. The reading variable was coded from low, with a value of "0" to high that was coded with a value of "4". Students were asked about their opportunity to learn a foreign language and "yes" was coded with a value of "1" and "no" was coded with a value of "0".

\section{Summary}

This chapter justified the use of the theoretical framework, research design, and statistical analysis to answer the research questions. Using Astin's I-E-O model as the framework, the previous chapter described in detail the variables in Blocks 1 and 2, which comprise the inputs. Blocks 3, 4, 5, and 6 are considered the environmental blocks, and after controlling for the effects of Blocks 1 and 2, a hierarchical linear regression analysis can determine the added variance in each model that is explained by the addition of each block. This section also laid out the individual variables and the coding scheme for each block.

Chapter Four describes the analysis of the results of the study. It is organized by research questions, including charts and graphs for a visual representation of the results. 


\section{Chapter Four \\ Analysis}

\section{Synopsis of Study}

In the context of the affirmative-action programs in Brazil, previous studies have argued that quota students are neither underperforming nor are they lowering academic standards for the institution. No research has considered environmental variables that might influence quota-students' academic achievement. The goal of the Law of Social Quotas is to increase equity for Brown and Black students, who previously were not adequately represented in the space of higher education. To effectively achieve this goal, university administrators, faculty members, and government officials need to know what factors can and are influencing their success. ${ }^{30}$ The present study examined the effects of student and family characteristics, economic factors, social support, and individual student involvement in exam achievement among quota-admitted students in Brazilian federal universities.

The study used quantitative methodology to measure the impact of environmental factors on student outcome. The conceptual framework followed Astin's (1993) I-E-O model, which supports the use of ordinary least squares when measuring student-level results from various universities instead of the more traditionally used hierarchical linear model (Astin \& Denson, 2009). By accounting for previous abilities and characteristics, through the inputs block, the correlation relationship between the environmental and

\footnotetext{
${ }^{30}$ Not in the scope of this study is the attrition rate of higher education students in Brazil in general, which is speculated to be very high (L. F. Schwartzman \& Paiva, 2016). One would suspect that for underrepresented students that number might be higher. However, Cardoso (2008) and Bezzera (2011) found that quota-students had lower attrition rate than non-quota students.
} 
outcome (dependent) variables are uncovered. The independent variables used in this study were derived from a combination of Brazilian and U.S based retention research works for an inclusive model. The research is guided by the primary research question and the six additional questions have been discussed in the previous chapter,

Chapter Four summarizes the study and provides an in-depth description of the results of the statistical analysis performed to answer the six research questions. There is one dependent variable - the total ENADE exam score.

\section{Hierarchical Analysis Results}

A hierarchical multiple regression was performed to determine the extent to which the addition of high school factors, pre-college variables, economic factors, social support variables, and individual involvement variables obtained from a survey improved the prediction of ENADE (college exit exam) scores over and above the family and student characteristic variables alone.

The full model, inclusive of family income, age, sex, race, parents' education levels taken individually, location of the high school, traditional vs non-traditional high school, public or private high school, reason for choosing major, proximity of the university to home, evening student, on-campus living, SES or disability quota type, STEM vs non-STEM majors, highly selective university, awarded scholarship, provision of academic involvement scholarship, contribution to family finances, retention services financial needs, working student, institutional and faculty support, support received while facing challenges, general social support to attend college, reading for pleasure, availability of opportunity to learn a foreign language, and number of hours spent 
studying - to predict ENADE overall scores (Model 6) was statistically significant; $\mathrm{R}^{2}=$ $0.104, F(3,6529)=50.915, \mathrm{p}<.001 ;$ adjusted $\mathrm{R}^{2}=0.10$. In other words, the model explains $10 \%$ of the variance in scores. See Table 14 for further details on each regression model.

Description of the population. The participants in this study were quotaadmitted, bachelor's degree students in their final year of studies in federal universities in Brazil who have completed the ENADE exam and the socioeconomic status survey. The original population $\mathrm{N}=7,215$ became $\mathrm{N}=6,557$ after cleaning up the data. The participants $(\mathrm{N}=6,557)$ answered questions about personal and family characteristics, such as age, sex, race, parents' educational levels considered individually, and family income. A frequency distribution summarizes the results in Table 9. The frequency table is organized by block; this table represents the data input in Block 1 - Personal characteristics and family factors.

Table 8. Frequency Distributions: Personal Characteristics and Family Factors $(N=$ 6,557)

\begin{tabular}{|l|l|l|}
\hline Personal characteristics & Frequency & Percent \\
\hline Age & & \\
\hline $\mathbf{2 0 - 2 1}$ & 423 & $6.5 \%$ \\
\hline $\mathbf{2 2 - 2 5}$ & 3968 & $60.5 \%$ \\
\hline $\mathbf{2 6 - 2 8}$ & 1146 & $17.5 \%$ \\
\hline $\mathbf{2 9 - 3 9}$ & 882 & $13.5 \%$ \\
\hline $\mathbf{4 0 - 6 1}$ & 138 & $2.1 \%$ \\
\hline
\end{tabular}




\begin{tabular}{|l|l|l|}
\hline Sex & & \\
\hline Male & 2055 & $31.3 \%$ \\
\hline Female & 4502 & $68.7 \%$ \\
\hline Race & & \\
\hline White & 2744 & $41.9 \%$ \\
\hline Non-White & 3813 & $58.2 \%$ \\
\hline Mother's educational level & & \\
\hline None & 196 & $3.00 \%$ \\
\hline Elementary & 1472 & $22.5 \%$ \\
\hline Middle school & 1016 & $15.5 \%$ \\
\hline High school & 2449 & $37.3 \%$ \\
\hline College & 894 & $13.6 \%$ \\
\hline Graduate school & 530 & $8.1 \%$ \\
\hline Father's educational level & & $32.0 \%$ \\
\hline None & 440 & $6.7 \%$ \\
\hline Elementary & 2017 & $30.8 \%$ \\
\hline Middle School & 1123 & $17.1 \%$ \\
\hline High School & 2098 & \\
\hline College & 709 & \\
\hline Graduate School & & \\
\hline Family income & & \\
\hline Up to 1.5 min wage & & \\
\hline 1.5-3 MW & & \\
\hline & & \\
\hline
\end{tabular}




\begin{tabular}{|l|l|l|}
\hline 3-4.5 MW & 1087 & $16.6 \%$ \\
\hline $\mathbf{4 . 5}-\mathbf{6}$ MW & 706 & $10.8 \%$ \\
\hline 6-10 MW & 437 & $6.7 \%$ \\
\hline $\mathbf{1 0}-30$ MW & 205 & $3.1 \%$ \\
\hline Beyond 30 & 10 & $0.2 \%$ \\
\hline
\end{tabular}

As shown in Table 8, the students ranged in age from 20 to 61 years. The broadest group range was $22-25$ years old $(\mathrm{N}=3,968,60.5 \%)$. The majority of the participants reported their gender as female $(\mathrm{N}=4,502,68.7 \%)$. Most students were non-white $(\mathrm{N}=3,813,58.2 \%)$ with the remaining reporting being White.

The participants also provided information on family income and parental academic levels. For mother's educational level, students' responses show that $3 \%$ $(\mathrm{N}=196)$ reported no schooling, $22.4 \%(\mathrm{~N}=1,472)$ completed elementary school, and $15.5 \%(\mathrm{~N}=1,016)$ completed middle school. High school completion constituted the largest group with $37.4 \%(\mathrm{~N}=2,564), 13.6 \%(\mathrm{~N}=894)$ reported college graduation, and $8.1 \%(\mathrm{~N}=530)$ obtained a graduate degree.

Approximately $7 \%(\mathrm{~N}=440)$ of students reported that their fathers have not received schooling. Elementary education constituted the second largest group at 30.8\% $(\mathrm{N}=2,017)$. Students reported middle school completion at $17.1 \%(\mathrm{~N}=1,186)$, and high school constituted the largest group at $32.0 \%(\mathrm{~N}=2,194)$. College completion constituted $10.8 \%(\mathrm{~N}=773)$ and $2.6 \%(\mathrm{~N}=184)$ completed graduate degree. Family income category was broken down into seven categories from smallest to largest; the first two - less than 1.5 times the minimum wage $(\mathrm{N}=1,889,28.8 \%)$ and between 1.5 to 3 times the minimum wage $(\mathrm{N}=2,223,33.9 \%)$ - in combination represented over half of the population. 
Representing the variables in Block two high school variables, students were asked questions about their high school location, type, and courses. A summary of the results is shown in Frequency Table 9. These are all of the variables in Block $\mathbf{2}$ - High school variables.

Table 9. Frequency Distributions: High School Variables $(N=6,557)$

High school variables Frequency Percent

\begin{tabular}{lcc}
\hline High school location & & \\
\hline Other & 4336 & $66.1 \%$ \\
SP, RJ, MG, ES & 2221 & $33.9 \%$ \\
High school type & & \\
\hline Private & 410 & $6.3 \%$ \\
Public & 6147 & $93.7 \%$
\end{tabular}

High school courses

$\begin{array}{lcc}\text { Traditional } & 5572 & 84.5 \% \\ \text { Non-traditional } & 1015 & 15.5 \%\end{array}$

The high school location variable was recoded to show the South-eastern states São Paulo (SP), Rio de Janeiro (RJ), Minas Gerais (MG), and Espírito Santo (ES). Together, these four states represented 33.9\% $(\mathrm{N}=2221)$, and all the remaining states combined represent $66.1 \%(\mathrm{~N}=4,336)$ of the population.

Students responded to whether their high school was public or private. The majority responded that they attended public schools $(\mathrm{N}=6,147,93.7 \%)$, and the remaining $6.3 \%(\mathrm{~N}=410)$ attended private schools. Eighty-four percent of the students 
responded that they attended traditional high schools $(\mathrm{N}=5,542)$ while the remaining $(\mathrm{N}=1,015,15.5 \%)$ participated in non-traditional programs.

Students were asked questions about the time of college attendance, living arrangements, type of affirmative-action, choice of major (STEM vs. non-STEM), why they chose their particular university, whether they selected a particular major due to the labor market or prestige, and institutional selectivity. These variables make up Block Three - Pre-college variables. Frequency Table 10 summarizes the results below. Table 10. Frequency Distributions: Pre-college Variable $(N=6,557)$

\begin{tabular}{lcc}
\hline Pre-college variables & Frequency & Percent \\
\hline Evening student & 1,038 & $15.8 \%$ \\
On campus living & 283 & $4.3 \%$ \\
Admitted under SES or disability quota & 709 & $10.8 \%$ \\
STEM majors & 5,424 & $82.7 \%$ \\
Selected major based on labour market/social prestige & 1,147 & $17.5 \%$ \\
Primary reason for selecting institution: proximity to & 461 & $7.0 \%$ \\
home & & \\
Intuitional selectivity: High ranked & 1,332 & $20.3 \%$
\end{tabular}

Approximately $16 \%$ of the students in the study were evening students $(\mathrm{N}=1,038)$. The remaining were either day or mid-day students $(\mathrm{N}=5,519,84 \%)$. A small percentage of the students reported living on campus $(\mathrm{N}=283,4.3 \%)$ with the majority residing in other arrangements $(\mathrm{N}=6,274,95.7 \%) .709$ students reported being admitted under the socioeconomic status or disability quota categories $(10.8 \%)$ while the majority of students cited being admitted under other categories $(\mathrm{N}=5,848,89.2 \%)$. A majority of the 
students in the population reported pursuing STEM majors $(\mathrm{N}=5,424,82.7 \%)$. When asked about their major selection choice, $17.5 \%(\mathrm{~N}=1147)$ stated that labour market or prestige were the primary reasons. The remaining students listed other answers $(\mathrm{N}=5,410$, $82.5 \%)$

When asked why a student selected a particular university, $7.0 \%(\mathrm{~N}=461)$ responded proximity to home as the primary reason. The remaining $93.0 \%$ chose other answers $(\mathrm{N}=6,096)$. An estimated $20 \%$ of students in the population studied in highly selective institutions $(\mathrm{N}=1,332)$, while the remaining $(79.7 \%, \mathrm{~N}=5225)$ did not.

The participants provided information about their finances and about whether they worked while in college, received retention services (i.e., food stipend, housing stipend), received scholarships to attend university, or earned academic scholarships while in college. These variables constitute Block Four - Economic factors. Table 11 presents the results of this analysis.

Table 11. Frequency Distributions: Economic Factors $(N=6,557)$

Economic Factors Frequency Percent

$\begin{array}{lll}\text { Contributed to family finances (Financial } & 469 & 7.2 \%\end{array}$
situation)

Working student

Received scholarship before entering

Received retention services

Earned academic scholarship during college
901

497

3402

4,443
$13.7 \%$

$7.6 \%$

$51.9 \%$

$67.8 \%$

Four hundred and sixty-nine (469) students (7.2\%) responded that they contributed to family finances while in college. Nine hundred and one (901) (13.7\%) 
reported working while in college. Nearly 500 (7.6\%) earned scholarships to attend university while $67.8 \%(\mathrm{~N}=4,443)$ earned academic scholarships during college. A little more than half of the students reported $(\mathrm{N}=3,402,51.9 \%)$ using retention services while in college. These include housing and meal stipends. Students provided information regarding support that they received to attend university and also during their college years. The information is summarised in Table 12 below and includes most of the variables in Block 5 - Social, institutional, and faculty support.

Table 12. Frequency Distributions: Social, Institutional, and Faculty Support $(N=6,557)$ Social, institutional, and faculty support $\quad$ Frequency Percent

\begin{tabular}{lcc}
\hline Received support to attend college & 5,813 & $88.7 \%$ \\
Received support during college & 5,386 & $82.1 \%$
\end{tabular}

A majority of students reported receiving support, in the form of encouragement, to attend college ( $\mathrm{N}=5,813,88.7 \%)$. Most students also reported receiving support while experiencing difficulties during college $(\mathrm{N}=5,386,82.1 \%)$. Students reported on studying habits (as measured by hours spent studying outside of class), reading for pleasure, and the opportunity to learn a foreign language. These variables combined constitute Block 6 - Individual involvement. The results of the analysis are summarized in Table 13.

The majority of students reported studying between 1 to 3 hours $(\mathrm{N}=1,960$, $29.9 \%)$ and 4 to 7 hours $(\mathrm{N}=2,168,33.0 \%)$. A similar number of students reported studying between 8 to 12 hours $(\mathrm{N}=1,192,18.2 \%)$ and more than 12 hours per week $(\mathrm{N}=1,163,17.7 \%)$. Seventy-seven (1.2\%) students reported no additional study hours beyond attending classes. 
Table 13. Frequency Distributions: Individual Involvement $(N=6,557)$

\begin{tabular}{|c|l|l|}
\hline Individual involvement & Frequency & Percent \\
\hline Hours spent studying & & \\
\hline None & 77 & $1.2 \%$ \\
\hline 1 to 3 hours & 1960 & $29.9 \%$ \\
\hline 4 to 7 hours & 2165 & $33.0 \%$ \\
\hline 8 to 12 hours & 1192 & $18.2 \%$ \\
\hline More than 12 hours & 1163 & $17.7 \%$ \\
\hline Reading for pleasure & & \\
\hline None & 1073 & $16.4 \%$ \\
\hline 1 or 2 books & 2643 & $40.3 \%$ \\
\hline 3 to 5 books & 1844 & $28.1 \%$ \\
\hline 6 to 8 books & 484 & $7.4 \%$ \\
\hline More than 8 books & 513 & $7.8 \%$ \\
\hline $\begin{array}{l}\text { Opportunity to learn a foreign } \\
\text { language }\end{array}$ & 3460 & $52.8 \%$ \\
\hline No & & $47.2 \%$ \\
\hline Yes & & \\
\hline
\end{tabular}

Most students reported reading one or two books $(\mathrm{N}=2,643,40.3 \%)$, followed by students who claimed to three to five books ( $\mathrm{N}=1844,28.1 \%)$. Nearly as many students reported not reading $(\mathrm{N}=1,073,16.4 \%)$ as did those who read between six to eight books $(\mathrm{N}=506,7.3 \%)$ and more than eight books $(\mathrm{N}=546,7.9 \%)$ combined. Three thousand and ninety-seven students $(47.2 \%)$ reported having the opportunity to learn a foreign language while the remainder $(\mathrm{N}=3,460,52.67)$ did not have the opportunity to read. 
Table 14.

Hierarchical Multiple Regression Predicting ENADE Scores ${ }^{31}$

\begin{tabular}{|c|c|c|c|c|c|c|c|c|c|c|c|c|}
\hline \multicolumn{13}{|c|}{ ENADE Overall Score } \\
\hline & \multicolumn{2}{|c|}{$\begin{array}{l}\text { Model 1- } \\
\text { RQ1 }\end{array}$} & \multicolumn{2}{|c|}{$\begin{array}{l}\text { Model 2- } \\
\text { RQ2 }\end{array}$} & \multicolumn{2}{|c|}{$\begin{array}{l}\text { Model 3- } \\
\text { RQ3 }\end{array}$} & \multicolumn{2}{|c|}{ Model 4 - RQ4 } & \multicolumn{2}{|c|}{$\begin{array}{l}\text { Model } 5 \text { - } \\
\text { RQ5 }\end{array}$} & \multicolumn{2}{|c|}{$\begin{array}{l}\text { Model 6- } \\
\text { RQ6 }\end{array}$} \\
\hline $\begin{array}{l}\text { Independe } \\
\text { nt variable }\end{array}$ & $\mathrm{B}$ & $\beta$ & $\mathrm{B}$ & $\beta$ & $\mathrm{B}$ & $\beta$ & $\mathrm{B}$ & $\beta$ & $\mathrm{B}$ & $\beta$ & $\mathrm{B}$ & $\beta$ \\
\hline (Constant) & $64.2 *$ & & $64.07 *$ & & $65.45^{*}$ & & $63.03^{*}$ & & $61.65^{*}$ & & $59.74 *$ & \\
\hline Age & $-0.28^{*}$ & -0.09 & $-0.30 *$ & -0.10 & $-0.30 *$ & -0.10 & $-0.26^{*}$ & 0.00 & $-0.26^{*}$ & 0.00 & $-0.26^{*}$ & -0.09 \\
\hline $\begin{array}{l}\text { Sex } \\
(\text { Female }=1)\end{array}$ & $-2.01 *$ & -0.07 & $-1.96^{*}$ & -0.07 & $-2.11 *$ & -0.07 & $-2.18^{*}$ & -0.08 & $-2.24 *$ & -0.08 & $-2.21 *$ & -0.08 \\
\hline $\begin{array}{l}\text { White/Non } \\
\text {-White } \\
\text { (White=0) }\end{array}$ & $-2.08^{*}$ & -0.08 & $-1.87 *$ & -0.07 & $-1.95 *$ & -0.07 & $-1.85^{*}$ & -0.07 & $-1.88 *$ & -0.07 & $-1.88^{*}$ & -0.07 \\
\hline
\end{tabular}

${ }^{31}$ The first column in the table identifies the variable. The table further includes two columns per model with a corresponding research question. The first column B represents the unstandardized beta coefficient and the second is the $\beta$-weight (also known as the standard beta coefficient) of the variable in that particular block. Towards the end of the table, the values for R2, the F ratio, the change in R2, and the change in F for each model are provided. Level of significance $\mathrm{p}<0.001$ is denoted by '*' 


\begin{tabular}{|c|c|c|c|c|c|c|c|c|c|c|c|c|}
\hline $\begin{array}{l}\text { Mother } \\
\text { educational } \\
\text { level }\end{array}$ & -0.19 & -0.02 & -0.14 & -0.01 & -0.13 & -0.01 & -0.10 & -0.01 & -0.10 & -0.01 & -0.10 & -0.01 \\
\hline $\begin{array}{l}\text { Father } \\
\text { educational } \\
\text { level }\end{array}$ & -0.05 & -0.01 & -0.05 & -0.00 & -0.06 & -0.01 & -0.09 & -0.01 & -0.07 & -0.01 & -0.08 & -0.01 \\
\hline $\begin{array}{l}\text { Family } \\
\text { income }\end{array}$ & $1.67 *$ & 0.17 & $1.63 *$ & 0.17 & $1.53 *$ & 0.16 & 1.53 & 0.16 & $1.55^{*}$ & 0.16 & $1.47 *$ & 0.15 \\
\hline $\begin{array}{l}\text { High } \\
\text { school } \\
\text { location }\end{array}$ & & & $2.08 *$ & 0.07 & $1.73 *$ & 0.06 & 1.61 & 0.06 & $1.60 *$ & 0.06 & $1.34 *$ & 0.05 \\
\hline $\begin{array}{l}\text { Public vs. } \\
\text { Private }\end{array}$ & & & 2.10 & 0.04 & 1.55 & 0.03 & 1.55 & 0.03 & 1.52 & 0.03 & 1.31 & 0.02 \\
\hline $\begin{array}{l}\text { Traditional } \\
\text { vs. Non- } \\
\text { traditional }\end{array}$ & & & $-2.66^{*}$ & -0.07 & $-2.66^{*}$ & -0.07 & -2.59 & -0.07 & $-2.60 *$ & -0.07 & $-2.69 *$ & -0.07 \\
\hline $\begin{array}{l}\text { Evening } \\
\text { student }\end{array}$ & & & & & -0.67 & -0.02 & -0.51 & -0.01 & -0.48 & -0.01 & -0.33 & -0.01 \\
\hline $\begin{array}{l}\text { On-campus } \\
\text { living }\end{array}$ & & & & & 0.91 & 0.01 & 0.44 & 0.01 & 0.40 & 0.01 & 0.01 & 0.00 \\
\hline
\end{tabular}




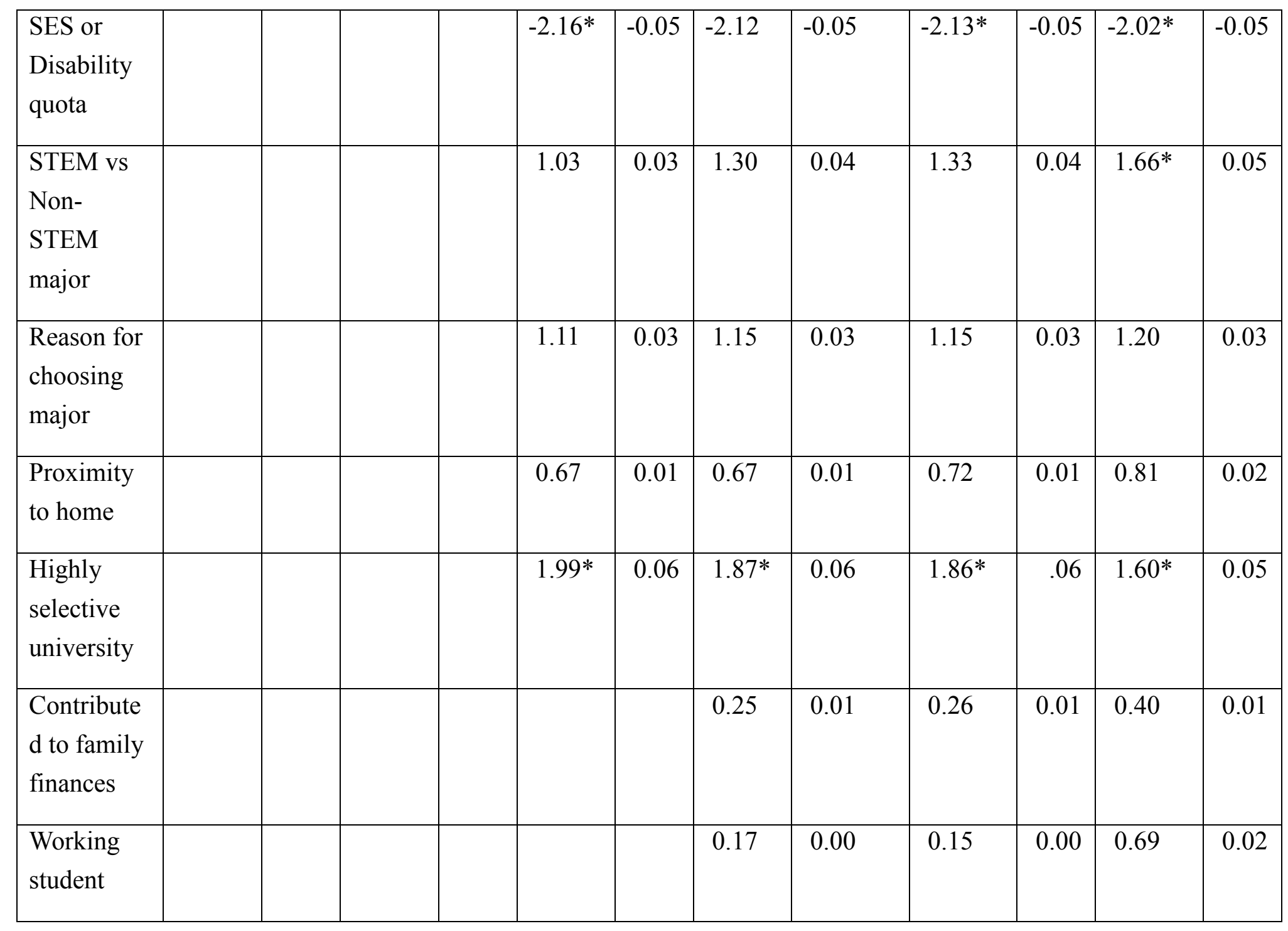




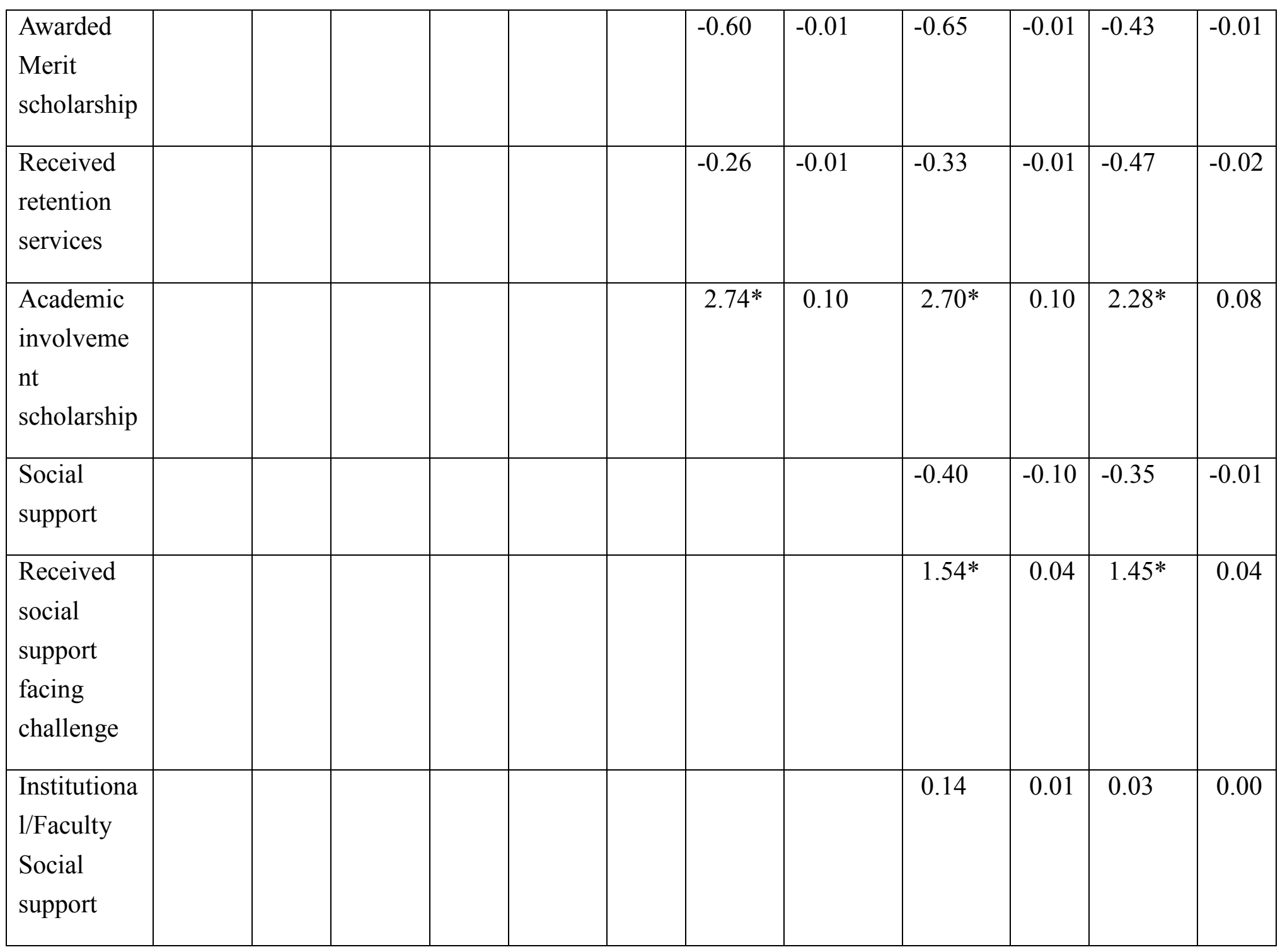




\begin{tabular}{|c|c|c|c|c|c|c|c|}
\hline $\begin{array}{l}\text { \# hours } \\
\text { spent } \\
\text { studying }\end{array}$ & & & & & & $1.71^{*}$ & 0.14 \\
\hline $\begin{array}{l}\text { Reading } \\
\text { for } \\
\text { pleasure }\end{array}$ & & & & & & $-0.53^{*}$ & -0.04 \\
\hline $\begin{array}{l}\text { Opp. to } \\
\text { learn a } \\
\text { foreign } \\
\text { language }\end{array}$ & & & & & & 1.00 & 0.04 \\
\hline$\overline{\mathbf{R}^{2}}$ & .052 & .065 & .073 & .081 & .083 & 104 & \\
\hline $\mathbf{F}$ & 59.74* & $50.33^{*}$ & $32.06^{*}$ & $27.48^{*}$ & $24.70^{*}$ & $28.12^{*}$ & \\
\hline$\Delta R^{2}$ & $.052 *$ & $.013^{*}$ & $.008^{*}$ & $.008^{*}$ & .002 & $.021^{*}$ & \\
\hline$\Delta \mathbf{F}$ & $59.74 *$ & $29.91 *$ & $8.08^{*}$ & $11.97^{*}$ & 4.88 & $50.92 *$ & \\
\hline
\end{tabular}

Note. $\mathrm{N}=6,557 . \mathrm{R}^{2}=0.104$, Adjusted $\mathrm{R}^{2}=0.100, \mathrm{~F}=28.12 *$ $* \mathrm{p}<.001$ 
Model framework summary. The primary research question guiding this study was what is the overall explanatory power of the full model? In other words, after including all of the variables (i.e., characteristics and family demographics, high school variables, pre-college variables, economic variables, social support variables, and individual involvement variables), how effectively does the model explain the performance of quota-admitted students in the ENADE exam? The sub questions are aligned with each block used in the hierarchical linear regression.

To address this question, a subset of six research questions focused on each block or set of variables determined by the researcher and a review of the literature. An OLS analysis with a hierarchical linear technique using block entry for each of the six steps was used to answer each of the six sub research questions. Following Astin's I-E-O framework, blocks 1,2, and 3 aimed to account for inputs that refer to the characteristics or abilities of students at the time of entry into the institution and which is known to have an effect or impact on the outcome measured. The input category is necessary to account for pre-existing abilities or factors that have a direct or indirect impact on the measured outcome (Astin, 1993). Blocks 4, 5, and 6 correspond to the subset research questions 4, 5, and 6 and represent the environment section of Astin's model. The environmental variables refer to the programs, people, and various aspects of college life that students are exposed to. Outcome variables are what the students gain after exposure to the environmental variables (while controlling for the input).

In applying this model to this study, the variables are grouped as follows:

- Input variables - Personal characteristics, family factors, secondary high school variables, and pre-college variables. 
- Environmental variables - Economic factors, social support variables, individual student involvement variables.

- Outcome variable - Overall ENADE college exit exam score.

The recommended alpha level to reduce type I error for each level is $\mathrm{p}<0.005$, rather than the traditional $\mathrm{p}<0.01$ (Astin \& Denson, 2009). The researcher used a $p$-value of $p<0.001$. The three steps are (1) block variables based on sequence in which they occurred (this is more commonly known as hierarchical linear regression), (2) allows the researchers to add each variable based on the (theoretical) predictive power, and (3) use the "beta in" feature to determine the added predictive value of the not yet added variable to the step.

\section{Research Questions}

The guiding research question for this study is as follows: What is the overall explanatory power of the full model? In other words, after including all of the variables (i.e., characteristics and family demographics, high school variables, pre-college variables, economic variables, social support variables, and individual involvement variables), how effectively does the model explain the performance of quota-admitted students in the ENADE exam? The sub questions are aligned with each block used in the hierarchical linear regression.

The full model (Model 6) explains 10\% of the variance (as represented by the adjusted $\mathrm{R}^{2}$ ) in the ENADE scores of quota-admitted students. Table 15 illustrates the findings for each of the research questions. The $+/$ - indicates whether the variable has a positive or negative effect on the dependent outcome (ENADE score), and the last column shows the standard beta coefficients in the model in which the variable is initially 
entered. The higher the $\beta$ (beta-weight or standard beta coefficients) value, regardless of +/-, the greater its effect on the dependent variable; this is, however, based on the assumption that the independent variables are not correlated (Courville \& Thompson, 2001). As previously stated, in this study, the independent variables are not highly correlated. There were four pairs of independent variables with correlations greater than $\mathrm{r}=0.3$ - Mothers' and fathers' educational attainment with an $\mathrm{r}=0.464, \mathrm{p}<0.001$ and retention services and income $r=-0.409, \mathrm{p}<0.001$. The other set of variables that were mildly correlated were income and mother's educational attainment $\mathrm{r}=0.373, \mathrm{p}<0.001$, and income and father's educational attainment $r=0.387, \mathrm{p}<0.001$. All of these variables were included in the model in Block 1 as inputs and considered together to control for this small correlation and are well below the threshold for the multicollinearity assumptions of a multiple regression generally set at $\mathrm{r}=0.7$.

Results for hierarchical linear regression are often misunderstood and at times misreported by researchers. It can be tempting to report the final step $\beta$ for all the variables when in reality the researcher is looking for the beta in or incremental variance that a particular variable contributes to the overall model; this is found in the step in which the variable is first added (Petrocelli, 2003; Schafer, 1991).

The $\beta$-weights presented in Table 15 suggest that family income and hours spent studying contribute most to predicting academic achievement. Furthermore, being male, White, and young; having attended a non-traditional high school in the Southeast region, been admitted via a non SES or disability quota, pursued a STEM major, attended a highly selective university, earned an academic involvement scholarship, and received social support when facing a challenge; and not reading for pleasure also contributed to 
this prediction. For Model 6, the R-squared value was 0.104 . This indicated that $10.4 \%$ of the variance in the academic success of quota-admitted students was explained by the model.

The effect size for a multiple regression can be measured by Cohen's $\mathrm{f}^{2}=\mathrm{R}^{2} /(1-$ $\mathrm{R}^{2}$ ) (Cohen, 1988). Cohen's (1988) guidelines state that $\mathrm{f}^{2} \geq 0.02, \mathrm{f}^{2} \geq 0.15$, and $\mathrm{f}^{2} \geq 0.35$ represent small, medium, and large effect sizes respectively. For Model 6, $\mathrm{f}^{2}=0.12$; according to Cohen (1988), this is a small effect. For the individual variables or a partial effect size evaluation, some use beta-weights or standardized beta coefficient (Courville \& Thompson, 2001).

In educational research, we are compelled to report the $\beta$-weights for each variable, and this information is included in the reporting of the results of each sub research question below. Nevertheless, the $\beta$-weights in this study are small and have limited implications, coupled with the low variance of the full model (10.4\%). A more expansive critique and explanation of the implication of these factors is included in Chapter 5.

Research Question 1: What influences do entering students' characteristics and family demographics have on the overall ENADE scores of quota-admitted students? The first block was the personal characteristics and family factors. The variables were age, sex, race, mothers' educational level, fathers' education level, and family income. As illustrated in Table 15, the step $\beta$-weight was -0.09 for age, -0.07 for sex, and -0.08 for race. The last variable from Block one was family income. In the entered model, its $\beta$ weight was 0.17 . The significant variables accounted for $5.2 \%$ of the variance in the 
ENADE scores of quota-admitted students. Income had the strongest effect when compared to the other variables using the $\beta$-weight (standardized beta coefficient).

Table 15. Summary of the Findings by Research Question

\begin{tabular}{|c|c|c|c|c|c|c|}
\hline $\begin{array}{l}\text { Research } \\
\text { Question }\end{array}$ & Findings & $\beta^{* *}$ & $\mathbf{R}^{2}$ & $\mathbf{F}$ & $\Delta \mathbf{R}^{2}$ & $\Delta \mathbf{F}$ \\
\hline \multirow{6}{*}{$\begin{array}{l}\text { RQ1. Students' } \\
\text { characteristics } \\
\text { and family } \\
\text { demographics }\end{array}$} & Age (-) & $-0.09 *$ & 0.052 & $59.74 *$ & $0.052 *$ & $59.74 *$ \\
\hline & Female (-) & $-0.07 *$ & & & & \\
\hline & Non-White (-) & $-0.08 *$ & & & & \\
\hline & Mother's Edu. (-) & -0.02 & & & & \\
\hline & Father's Edu. (-) & -0.01 & & & & \\
\hline & Family Income $(+)$ & $0.17^{*}$ & & & & \\
\hline \multirow[t]{3}{*}{$\begin{array}{l}\text { RQ2. High school } \\
\text { variables }\end{array}$} & $\begin{array}{l}\text { High School } \\
\text { Location (SP, RJ, } \\
\text { MG, ES) }(+)\end{array}$ & $0.07 *$ & 0.065 & $50.33^{*}$ & $0.013^{*}$ & $29.91 *$ \\
\hline & Public (+) & 0.04 & & & & \\
\hline & Traditional (-) & $-0.07 *$ & & & & \\
\hline \multirow{7}{*}{$\begin{array}{l}\text { RQ3. Pre-college } \\
\text { variables }\end{array}$} & Evening student (-) & -0.02 & 0.073 & $32.06^{*}$ & $0.008 *$ & $8.08^{*}$ \\
\hline & $\begin{array}{l}\text { On-campus living } \\
(+)\end{array}$ & 0.01 & & & & \\
\hline & $\begin{array}{l}\text { Type of Quota SES } \\
\text { or Disability (-) }\end{array}$ & $-0.05 *$ & & & & \\
\hline & $\operatorname{STEM}(+)$ & 0.03 & & & & \\
\hline & $\begin{array}{l}\text { Reason for } \\
\text { Choosing Major }(+)\end{array}$ & 0.03 & & & & \\
\hline & $\begin{array}{l}\text { Proximity to home } \\
(+)\end{array}$ & 0.01 & & & & \\
\hline & $\begin{array}{l}\text { Highly Selective } \\
\text { University }(+)\end{array}$ & $0.06^{*}$ & & & & \\
\hline
\end{tabular}




\begin{tabular}{|c|c|c|c|c|c|c|}
\hline \multirow[t]{5}{*}{$\begin{array}{l}\text { RQ4. Economic } \\
\text { variables }\end{array}$} & $\begin{array}{l}\text { Contributed to } \\
\text { family finances }(+)\end{array}$ & 0.01 & 0.081 & $27.48^{*}$ & $0.008 *$ & $11.97 *$ \\
\hline & Working student & 0.00 & & & & \\
\hline & $\begin{array}{l}\text { Awarded merit } \\
\text { scholarship (-) }\end{array}$ & -0.01 & & & & \\
\hline & $\begin{array}{l}\text { Received retention } \\
\text { services (-) }\end{array}$ & -0.01 & & & & \\
\hline & $\begin{array}{l}\text { Academic } \\
\text { Involvement } \\
\text { Scholarship (+) }\end{array}$ & $0.10 *$ & & & & \\
\hline \multirow{3}{*}{$\begin{array}{l}\text { RQ5. Social } \\
\text { support variables } \\
\text { inclusive of } \\
\text { institutional and } \\
\text { faculty support }\end{array}$} & Social Support (-) & -0.10 & 0.083 & $24.70 *$ & 0.002 & 4.88 \\
\hline & $\begin{array}{l}\text { Received Social } \\
\text { Support Facing } \\
\text { Challenge }(+)\end{array}$ & $0.04 *$ & & & & \\
\hline & $\begin{array}{l}\text { Institutional/Faculty } \\
\text { Support }(+)\end{array}$ & 0.01 & & & & \\
\hline \multirow{3}{*}{$\begin{array}{l}\text { RQ6. Individual } \\
\text { involvement } \\
\text { variables }\end{array}$} & $\begin{array}{l}\text { Number of hours } \\
\text { spent studying }(+)\end{array}$ & $0.14 *$ & 0.104 & $28.12 *$ & $0.021 *$ & $50.92 *$ \\
\hline & $\begin{array}{l}\text { Reading for } \\
\text { pleasure (-) }\end{array}$ & $-0.04 *$ & & & & \\
\hline & $\begin{array}{l}\text { Opp. to learn a } \\
\text { foreign language } \\
(+)\end{array}$ & 0.04 & & & & \\
\hline
\end{tabular}

$* p<0.001$

** $\beta$ this is the standardized beta coefficient in the step in which the variable is first entered.

Research Question 2: What influence do high school variables have on performance on the ENADE overall scores of quota-admitted students? The second block included a group of high school variables such as high school location, type (public or private), and type of courses (traditional vs. non-traditional). High school location had a $\beta$-weight of 0.07 in the entered model. The traditional vs. non-traditional course variables 
had a $\beta$-weight of -0.07 . Public high school attendance had a $\beta$-weight 0.04 . In other words, the addition of the three high school variables accounted for $1.3 \%$ variance in the ENADE score. Model 2 is a better predictor of ENADE success than Model 1, as demonstrated by the statistically significant change in $\Delta \mathrm{F}=29.91^{*}$. Model 2 explains a total of $6.5 \%$ of the variance, inclusive of the $5.2 \%$ that stems from the Block 1 variables (age, gender, race, and family income).

Research Question 3: What influence do pre-college variables have on performance on the ENADE overall scores of quota-admitted students? The third block focused on students' responses related to pre-college variables. The variables included in this block were - time of attendance and whether living on campus, availed disability or SES quota, pursued STEM or non-STEM majors, selected major based on prestige or labour market, selected university based on proximity to home, and whether the institution is highly selective. As illustrated in Table 15, these variables from the precollege variables block contributed to the explanation of a quota-students' academic performance on the ENADE exam score. In other words, while controlling for the variables in Blocks 1 and 2, variables in Block 3 has added to the prediction of ENADE scores of quota-admitted students. Being an evening student had a $\beta$-weight of -0.02 , while living on campus had a $\beta$-weight of 0.01 . Type of quota SES or disability had $\beta$ weight of -0.05 . STEM vs. Non-STEM majors had a $\beta$-weight of 0.03 . The last three variables in this block to enter the last model were: reason for choosing major with $\beta$ weight of 0.03 , proximity to home with $\beta$-weight of 0.01 , and highly selective university, with a $\beta$-weight of 0.06 . The addition of the variables in the third block significantly increased the ENADE's scores prediction as demonstrated by the $\Delta \mathrm{F}=8.08^{*}$. These 
variables combined explained $0.8 \%$ of the variance in ENADE scores, which combined with Models 1 and 2, brings Model 3 variance explanation to $7.3 \%$.

Research Question 4: What influence do economic variables (after controlling for the above variables) have on performance on the ENADE overall scores of quotaadmitted students? Students provided information regarding economic factors; these constituted Block four. The variables included in the economic factors block were financial situation, working status, and whether received a scholarship, retention services, and academic involvement scholarships. The variables included in the economic factors block were the contributed to family finances ( $\beta$-weight 0.01$)$, working student ( $\beta$-weight 0.00), received merit scholarship ( $\beta$-weight -0.01$)$, received retention services $(\beta$-weight 0.01 ), and academic involvement scholarships ( $\beta$-weight 0.10$)$. The addition of the economic variables added to $0.2 \%$ of the variance of the ENADE scores. In total, Model 4 explains $8.1 \%$ of the variance in ENADE scores.

Research Question 5: What influence do social support variables, inclusive of institutional and faculty support (after controlling for the above variables) have on performance on the ENADE overall scores of quota-admitted students? An average score in institutional and faculty support, general social support to attend college, and social support provided in challenging times during college comprised the fifth block that aimed to answer the fifth research question. The general social support variable had a $\beta$-weight of -0.10 , while received social support while facing challenge had a $\beta$-weight of 0.04 , and institutional and faculty support variable had a $\beta$-weight 0.01 . The addition of these variable increased the variance explanation by $0.2 \%$. Model 5 as a whole was a statistically significant model that explained $8.3 \%$ of the variance in scores of quota- 
admitted students. Students who reported receiving social support while facing challenges in college scored higher on their ENADE exams.

Research question 6: What influence do individual involvement variables (after controlling for the above variables) have on performance on the ENADE overall scores of quota-admitted students? Students responded to questions about their habits during college. These questions comprised the sixth and final block, individual student involvement. Three variables were included in this block - number of hours students spent studying outside of class, number of books read for pleasure, and whether or not the student had an opportunity to learn a foreign language. The number of hours that the students spent studying had a $\beta$-weight of 0.14 . Reading for pleasure had a $\beta$-weight of 0.04 . Opportunity to learn a foreign language has a $\beta$-weight of 0.04 . These variables combined contributed to $2.1 \%$ of the variance in the model. Combined, Model 6 predicts $10.4 \%$ of the variance in ENADE scores of quota-admitted students.

Students who spent more time studying scored higher in ENADE exams. The students who read more for pleasure scored lower. The association between these two variables and the ENADE scores is either weak or the effect size is small.

\section{Summary}

This chapter presented the results of the analyses and described the population used in this study. The original population included $\mathrm{N}=7,215$; ultimately the sample was reduced to $\mathrm{N}=6,557$ due to missing variables. The participants' ages ranged from 20-61 years old. The majority were female (68.7\%) and non-White (58.2\%). A little more than half of the students reported family earnings that were less than three times the minimum wage. Almost all attended public high schools (93.8\%), and 82.7\% selected STEM 
majors in college. One-fifth attended highly selective universities. Close to half utilized retention services while in college and $67.8 \%$ earned academic involvement scholarship during college. The majority (82\%) reported receiving support during college while facing challenging situations.

A key research question and six sub questions guided the study. These were developed with the aim of identifying the factors that contributed to the academic success of quota-admitted students in federal universities in Brazil. The findings indicate that age, gender, race, family income, high school location, type of high school course, disability or SES quota type, STEM major, highly selective university, academic involvement scholarship, receiving social support while facing challenges, number of hours spent studying and reading for pleasure are all predictors of quota-students' success. The final model accounts for $10 \%$ of the variance in ENADE scores of the quota-admitted students. Chapter 5 presents a discussion of the findings and implications for practice and future research. 


\section{Chapter Five \\ Conclusions Implications and Recommendations \\ Summary of the Study}

This dissertation focused on understanding the factors that contributed to the relative success of students who have availed quotas in federal universities in Brazil following the implementation of an ambitious national quota-based affirmative-action plan aimed at improving the access for Black and Brown people who were previously excluded from federal universities. Using a national dataset curated by the Ministry of Education in Brazil, this research included all the students who graduated with a bachelor's degree in 2016, were quota-admitted, completed a socioeconomic questionnaire, and had given the ENADE exam $(\mathrm{N}=6,557)$.

The frameworks that guided the study included Astin's theory of student involvement (1993), social support theory (Malecki \& Demaray, 2006; Tardy, 1985), and Tinto’s theory of student departure (1975). Conceptually, Astin's I-E-O model was employed. It controls for students' existing abilities and personal and family characteristics before enrolling in college (input), the environment (including variables related to programs, events, and people who influenced students' success) as guided by the literature review from both U.S-based and Brazilian studies. Lastly, the dependent variable was the ENADE exam score. A hierarchical multiple regression was performed to determine the incremental effect that key environmental variables had on the outcome after controlling for the inputs with a conservative $p$-value set at $<0.001$. Including inputs, 27 variables were included in the model. The combined $\mathrm{R}^{2}$ is $10.4 \%$, which represented 
the variance in the ENADE scores explained by the variables. This implies that close to $90 \%$ of the variance has not been explained yet.

This research provides some answers to the predictors contributing to quotastudents' success. These findings, though limited due to their explanation of $10 \%$ of the variance, are still important. It has linked social support, economic factors, and student involvement positively and negatively associated with ENADE exam scores. This research has contributed to the literature by expanding U.S-based student development theories, particularly Astin's theory of student involvement in a new population. In general, its findings are similar to what has been found in the U.S. population, but the model was ineffective in explaining a large portion of the outcome, leaving $90 \%$ of the variance of academic achievement unexplained and raises questions about the role of the environment as postulated by Astin's Theory of Student Involvement in Brazilian quotastudents. Overall, this study provides a foundation for additional studies to determine the factors that are contributing to quota-students' successes in federal universities in Brazil. Understanding the factors that contribute to success can help guide political actors, university administrations, and students to make evidence-based decisions on improving achievement for the half of the population in Brazil who are underrepresented in the higher education sphere. Furthermore, the results of this study demonstrate a need for additional research to understand the other factors that contribute to to quota-student success. Lastly, it leaves room for further critique of the ENADE exam (dependent variable) in assessing student performance. 


\section{Discussion of the Findings}

Brazil's complicated history with race, miscegenation, late-development of the university and universal public education, and the late abolishment of slavery fostered an environment of second-class citizens. The federal government's delayed action to address inequalities and recognize racism in Brazil contributed to the perpetuation of the racial democracy myth. The myth links poverty to lack of opportunities and poor living conditions rather than racial discrimination. The majority of Black and Brown people in Brazil are poor and lack education. In $2014,70 \%$ of those who did not complete any schooling were Black, while of those who completed higher education, $70 \%$ were White (Instituto Brasileiro de Geografia e Estatística, 2017). ${ }^{32}$ The law of social quotas aims to address this significant disparity in educational attainment. This study sought to understand factors that contribute to quota students' success in federal universities in Brazil. The merits of this study are increasingly consequential as Brazil faces the rise of nationalist sentiment that threatens the existence and legitimacy of the current quota system with the new President Jair Bolsonaro (De Souza \& France-Presse, 2018).

The findings of this study conclude that 26 of the 27 variables were associated with academic achievement as measured by scores in the ENADE exam for quotaadmitted students in Brazilian federal universities. Working student was the only variable with a beta weight of 0 . A few key characteristics that were associated with higher performance on the ENADE exam were (a) being younger, (b) being male, (c) being White, (d) having a higher family income, (e) having graduated from a high school

\footnotetext{
${ }^{32}$ In this data Black represents Black and mixed-race individuals.
} 
located in São Paulo (SP), Rio de Janeiro (RJ), Mato Grosso (MG), or Espírito Santo (ES), (f) having studied in a non-traditional high school (such as technical or teaching credential schools), (g) entering university through a quota other than SES or disability, (h) pursuing a STEM major, (i) attending a highly selective university, (j) earning an academic involvement scholarship (similar to teaching, research or other graduate assistantship in the U.S.), (k) receiving social support when facing challenges during university, (l) spending more time studying, and (m) reading less for pleasure.

The findings above explain that approximately $10 \%$ of the variance in the ENADE exam scores of students admitted via quota to federal universities in Brazil. This suggests that the final model leaves $90 \%$ of variance without explanation and thus can be improved. The present study included comprehensive variables that have been traditionally used to predict or explain academic achievements such as race, gender, family income, parental education, institutional selectivity, financial factors, and involvement in college. Despite the variety of variables used, the model explained only a small variation in student success.

The exclusion of control variables that account for previous academic success or that refer to abilities such as high school GPA or SAT scores, measures that could control for incoming student ability in the model, is noteworthy. Astin (1993) emphasized the importance of such a variable because of its relationship with academic success in college. While the inclusion might make the model more accurate or arguably increase its explained variance, the researcher did not have access to this information. Furthermore, two important factors make Brazil's college admission process different and less reliable in this association between entrance scores and academic success. First, the college 
admissions process in Brazil does not take into account high school grades. The system is based on scores on either the ENEM or the vestibular. Secondly, Bezzerra (2010), Childs \& Stromquist (2015) and others have found that the entrance exam scores are a weak predictor of academic success in quota-students. Therefore, while the lack of information regarding previous academic performance is a limitation, it is it is a limitation of a considerably lesser degree than if the study site was the U.S.

One of the strengths of the hierarchical multiple regression model is its ability to determine the incremental impact of variables after controlling for others. The next section will address the significant predictors corresponding to each of the six research questions organized by blocks.

\section{Input variables, personal, and family characteristics variables, Block 1. In}

addressing the first sub research question - what influence do entering students' characteristic and family demographics have on performance on the overall ENADE scores of quota-admitted students? - it was observed that age, sex, race, and family income are related to performance in the ENADE exam. Mother and Father's educational level had mix results. The findings suggest that younger students score higher or perform better academically compared to older students. This finding supports previous research by Pedrosa et al. (2007). Approximately 33\% of students who enrolled through quota are more than 25 years old. This finding suggests that older students face different challenges from younger ones. Moreover, university administrators, faculty, and students should be aware of this gap and devote additional resources directed at bridging it, including conducting and encouraging further research and meeting program evaluation needs of older students on campus. 
Approximately $40 \%$ of students who enrolled through quota self-identified as White. In the model, being non-White was a predictor of lower ENADE scores. This finding is congruent with previous literature and points to the necessity of additional research to understand this large percentange, given that the Law of Social Quota was create to increase equity for Brown and Black Brazilians in Federal Universities. Initially, this number seems high. The Law of Social Quotas primary criterion is public high school attendance, from there, it prioritizes beneficiaries based on socioeconomic status or race; a combination is also available. I argue that there are two factors that may be responsible for the large percentages of self-identified White quota-students. First, there could be a whitening effect, and second, the higher concentration of STEM majors in the population of this study could have whitened the population.

Let us consider the first possibility, the whitening effect. Students who responded to the questionnaire for the study have either completed their bachelors' degree or are in their last semester. Bailey (2008) and more recently Loveman et al. (2012), demonstrated a whitening effect of the population when questions on race were constructed differently. In both studies, when provided a dichotomous option for selecting Black or White, more mixed-race individuals chose White. Is there a whitening effect during college for students admitted via quota? In other words, is it possible that students changed their race identification upon completing their degrees? A future study should explore changes in the racial identity of students admitted via quota.

The second factor that could explain the large percentage of Whites in this study is their major choices. In the present study, the majority of students are pursuing studies in the STEM field, which has been shown to have a higher selectivity and a lower 
likelihood of quota-student enrollments (Dias Lopes, 2017; Francis \& Tannuri-Pianto, 2012a). Previous studies have shown that attrition rates for quota-admitted students are lower than their non-quota counterparts (Bezzera, 2010; Cardoso, 2008; Childs \& Stromquist, 2015). Additional research is required to understand the large portion of White students who are benefiting from the quota system. This finding raises the question: Whom do the quotas benefit? If the purpose of the quota is to expand access to Black and Brown students as I and others have claimed, these findings are gloomy.

Htun (2004) argued that the delay in race classification contributed to the perpetuation of the racial democracy myth. Bailey and Telles (2006) contend, despite the racial continuum and challenges with classification in Brazil, "the existence of historic and contemporary racial discrimination is perhaps the only justification for state counting race in the first place (p. 97)". The case of the UnB twins, one who was admitted based on a photograph and the other who was not due to differences in physiognomy and another instance in which a person asked, "If my grandmother is Black am I Black?" exemplify the intricacies and the sustained lack of awareness of racial identity (Maggie \& Fry, 2004). When asked if quotas should be based on race or socioeconomic status, most students and administrators insist on focusing on socioeconomic status since it is a fairer method (Schwartzman \& da Silva, 2012). Socioeconomic status, while highly correlated with race in Brazil, may not be an adequate criterion to expand access to Black and Brown students in STEM majors as demonstrated by the high percentage of Whites in the population studied.

Being female is associated with lower standardized scores (Mendes Junior et al., 2016), which was also the finding in this study. The population used in this study were 
mostly STEM majors. Notably, in another study, being female was more adverse to standardized academic performance than quota-status (Valente \& Berry, 2017). By research design, all women in the population studied were quota-admitted; therefore, this finding is not surprising. This finding has mixed implications because of the nested nature of the majors included in this study with $82 \%$ of participants in STEM degrees. It is challenging to extricate whether the lower academic performance of women observed in this study is associated with STEM fields, which requires further research if true, or if their performance is poor regardless of the major of study.

In previous studies, being non-White has been associated with lower academic performance when compared to that of White peers (Francis \& Tannuri-Pianto, 2012a; Valente \& Berry, 2017). The present finding supports the literature, that is, being nonWhite shows a negative relationship with academic performance. The results provide further credence to the argument that race-based programs are necessary to address the racial inequality in Brazil. It should be noted that in this study, only quota-admitted students were analyzed, almost all had previously studied in public high schools (94\%), $68 \%$ were female, $41 \%$ were White, and $82 \%$ were STEM majors. Nevertheless, race still emerged as a significant factor in lower scores.

Higher family income was positively related to academic performance; this supports previous research (Mendes Junior et al., 2016).

The input variables are included in the model to control for the effects of the abilities and attributes that students come to college with so that the researcher can determine the incremental impact of the environmental variables on the outcome. Blocks 1 and 2 are inputs as defined by Astin's (1993) I-E-O model. Surprisingly, however, 
parents' educational achievement levels considered individually had little effect on students' ENADE scores. This contradicts previous findings. Valente and Berry (2017) concluded that mother's and father's educational levels are positively significantly related to public university students' $(\mathrm{N}=262,796)$ academic performance. Note that in this study, the researcher examined only federal university students who had enrolled via quota $(\mathrm{N}=6,557)$. Interestingly, Waltenberg and Carvalho (2013) opted for a combined measure of parental education as a proxy for the family's socioeconomic status, arguing that asking students for income information is an unstable measure. This finding implies that quota students' success may not be directly related to that of their parents. In other words, the relationship between parental academic attainment and quota-student success might not be linear. If a parent earns a high school diploma, it does not imply that his or her son is more likely to perform better in the ENADE exam as compared to a student whose father has received no schooling. However, further research is required before asserting that parental education is not linked to student performance.

Input variables, high school factors, block 2. The variables in the second block

focused on high school factors such as location, traditional vs. non-traditional high school courses, and private or public type. The location variables were recoded to include the South-eastern states of Brazil, generally regarded as the economically strongest, densely populated, and with a large number of federal universities. There was a positive relationship between students who attended high school in this region and their ENADE exam score. It can be argued that more populated and economically advantaged areas have higher competition and thus, those students who enter a competitive university such as the federal ones are poised to succeed academically compared to students in other 
areas who lack the economic advantage of higher GPD and have less competition to enter universities.

There is a negative relationship between traditional high schools and ENADE scores. Pedrosa et al. (2007) yielded a similar result in their study of University of Campinas students that aimed at determining factors that contributed to higher relative performance. It was postulated that students who attend technical high schools are required to undergo admission exams and thus, those schools are more selective (Pedrosa et al., 2007). An estimated $15.5 \%$ of quota-admitted students attended non-traditional high schools. In addition to Pedrosa et al.'s (2007) speculation on the entrance examination requirement, this study's finding compels researchers and government actors to understand how and why students from non-traditional schools perform better than the other students.

Public or private high school type was not a key predictor. Initially, this may seem to be an unexpected finding. However, it is not surprising given that the quota system is primarily based on public high school criteria, and the majority of the study sample attended public high school (94\%).

As with the first block, Block 2 is also an input block. The variables were hypothesized to be significantly associated with ENADE exam scores, given the literature review presented in Chapter 2. Recall that variables in Blocks one and two were included as a control to measure the impact of the variables in the subsequent blocks.

Bridge block, pre-college variables, Block 3. Astin (1993) described variables that were neither input or environmental (programs or activities that took place during college) that could impact the outcome as "bridge variables". For example, students 
select their major before entering college; however, their major selection has an impact on their environment. Another example is living arrangements. ${ }^{33}$ If you live on campus, your environment changes and can subsequently influence your outcome. Three variables in Block 3 were significant predictors of academic success among students who enrolled via quota - enrollment in socioeconomic or disability-quota category, STEM majors, and highly selective universities.

Students admitted under the low socio-economic or disability-quota category had a negative impact on performance. This is supported in the literature (Valente \& Berry, 2017). There is a positive relationship between selecting STEM majors and higher academic achievement in the ENADE exam. This finding was anticipated since STEM majors are more selective and require higher scores on the entrance exams (Dias Lopes, 2017). Astin (1993) recommends accounting for institutional differences by controlling for size, selectivity, and organisation (public or private). Since all the selected sites are federal universities in this study, a variable for selectivity was implemented. Furthermore, a positive relationship between highly selective universities and academic performance was located. None of the other variables in this group were significant.

These findings are true after controlling for variables in Blocks 1 and 2. The low impact of the variables included in the model and lack explicability of overall model to predict ENADE exam score of quota-admitted students, are unexpected and open up new areas for future study. Time of attendance was not a significant predictor since factors

\footnotetext{
${ }^{33}$ In Brazil students are required to decide on a major before applying to a university. A major cannot be changed once admitted; instead a student would need to reapply under a different major should he want to switch.
} 
such as such as going to school in the evening comprised of only $16 \%$ of the students in this study. The researcher expected a negative association between evening status and academic performance. For example, living on campus has small positive effect on quotastudent academic performance. The I-E-O model and previous studies based in the U.S. have linked living on-campus with higher academic achievement. The degree uncovered in this study is a weaker link due to the unexplained variance $(90 \%)$ that contributes to a quota-student's academic performance. In general, universities in Brazil are not typically residential and do not cultivate the same culture of living your first year on campus as in the U.S. It may be that living with parents would have been a better option for study, given that only $4.3 \%$ of students reported living on campus.

Economic factors, Block 4. The first environment block is number four. Receiving an academic involvement scholarship was positively associated with higher scores. This variable can be viewed through on campus employment or a student involvement lens since students earn funds for academic work performed alongside faculty or staff. This finding is congruent with Astin's theory of student involvement and supports other studies that argue that on-campus employment has a positive effect on students' academic outcomes. As defined by Astin (1999), the quality and quantity of the educational activity performed by students are positively related to student learning and development. This finding extends Astin's (1993) theory of student involvement to different populations. At the same time, Portes (2001), while studying six Brazilian university students whom he calls "statistical improbabilities", also support these findings. He mentions that research involvement and on campus employment had a positive effect on the successful trajectory of some underprivileged students. Others had 
not found their way into these opportunities and felt confused in the process (Portes, 2001). Approximately two-thirds of the students in this study reported receiving academic involvement scholarships.

An estimated, two-thirds of the students in this study participated in "academic involvement scholarship". This variable grouped monetary academic opportunities such as research assistantship, coordinating projects such as community events and information dissemination for the public good, tutoring, and other similar programs often supported by the federal government and the university. At a glance, these programs successfully address two issues identified in the literature: (1) financial challenges and (2) lack of connection or involvement at university, which both contribute to student dropout (Astin, 1993; Tinto, 1975).

Academic involvement scholarship was a key predictor of academic performance of quota-admitted students after controlling for the variables in Blocks 1, 2, and 3. This finding suggests that regardless of race, sex, family income, high school location, and type of high school attendance, academic involvement scholarship alone is associated with the increased performance of quota students in the ENADE exam. University administrators and governmental actors should take notice and use this evidence to expand the offerings of such opportunities to as many quota-admitted students as possible. Researchers should investigate the factors that are responsible for this association, i.e., is it the connection with faculty, the extra funds provided to students, or other factors that are leading to this positive association?

Other variables that had lower impact on the ENADE exam performance, as measured by the beta weights, include, contributing to family finances, working while at 
university, being awarded a merit scholarship, and receiving retention services. All of these had been positively or negatively linked in previous literature to academic success. These findings again question the applicability of the I-E-O model and Astin's Theory of Student Involvement in a new population. Is the impact of the environment, as described by Astin (1993), less important to Brazilian university students?

Social, institutional, and faculty support variables, Block 5. The fifth research question examined the impact of social support on the academic achievements of students who enrolled via quotas. Students who reported receiving support while facing challenges during college scored higher in the exit exam. Previous U.S.-based studies have shown a positive relationship between perceived social support and academic achievement while controlling for aptitude (Cutrona et al., 1994). Positive university environment and social support have indicated a positive impact in Latino/a student population in the U.S (Gloria et al., 2005). Malecki and Demaray (2006) conducted a study among middle school children and those of lower-SES who perceived higher levels of social support and experienced better academic outcomes when compared to their peers with no support. No studies related to social support and Brazilian quota-students were found. This finding may suggest that social support can have a buffering effect on academic achievement, but further research is required to substantiate this claim. This is the weakest factor - note that while Model 5 is a significant model, the addition of the significant social support variable does not show a significant change in $\mathrm{R}^{2}$. In other words, the addition of the social support variable did not produce a significantly better-predicting model from Model 4. However, the variable was significant. 
This finding is consistent with previous U.S-based literature that has provided small and positive links between academic performance and social support (Crisp et al., 2015; Cutrona et al., 1994; de la Iglesia, Stover, \& Liporace, 2014), and in Brazil (Portes, 2001), this is the first time it has been linked to quota-admitted student success. Astin (1993), Tinto (1975), and Malecki and Demaray (2006) have linked social support to students' success and Portes (2001) and others (Viana, 1998; Zago, 2000) in the Brazilian context focused on the sociological framework and discussed the importance of social networks in the trajectory and success of underprivileged students in higher education. This finding in the study extends the work of the social support and student development theories from the U.S. into the examination of success among Brazilian university students.

In the present study, the researcher did not examine the impact of social support among males and females as separate groups, and previous research has pointed to perceived differences and effects among male and female college students in Argentina (de la Iglesia et al., 2014). This finding suggests that more research is required to further investigate the impact of social support among students admitted via quota in Brazilian federal universities. This study is limited in scope and care has been taken to ensure that its findings are not overstated since different variables, one linked to general support, and the other inclusive of faculty support, that was previously linked to student success in literature based in the U.S. was not as impactful in this study. The lack of effect uncovered could be related to gender differences.

Individual involvement variables, Block 6. The last research question examined individual student involvement variables to determine their impact on the academic 
achievement of students admitted via quota in federal universities in Brazil. Two factors were statistically significant predictors in this block. First, higher number of hours spent studying was a predictor of higher score in the ENADE exam. This finding supports seminal previous research (Astin, 1993; Tinto, 1975) on U.S. college student retention.

Inversely, students who reported reading [greater numbers of books] for pleasure were negative predictors of ENADE scores. The second variable represented the number of books read outside of class assignments, and the findings show a negative association with lower scores on the ENADE exam with an increase in the number of books read. This finding is congruent with Astin's (1993) theory of student involvement since students are devoting time to an activity that is not proportionally related to the educational goals, and this significantly affected the available time for academic endeavours. The last factor was opportunity to learn a foreign language, which had a small beta-weight 0.04 , and thus had small impact on the ENADE exam performance.

\section{Critique of Dependent Variable}

The outcome used in this study is the Brazil National Exam known as ENADE. It has been widely used as a proxy for student achievement, and its chief purpose is to evaluate programs at different institutions. The reliability and validity of this exam are unknown, yet researchers cannot use another form for standardizing student learning outcome to assess learning on a larger scale. However, given the low variance explained by the variables in the model, it may be important to emphasize the limitations of the ENADE exam.

Except for previous academic achievement which was a limitation of the study, most of the variables in the model included an arguably comprehensive set of 
independent factors that can explain student success. All students in the selected majors being evaluated at any given year are required to give the exam as a pre-requisite for earning the diploma; however, there is no incentive to perform well in the exam since the grade is not relevant and nor is there a passing grade.

This test may be inept at measuring student achievement. For example, the lack of student incentive to perform well makes it a problematic measure of student learning assessment. However, there is no viable alternative to measure aggregate student success and it is still the position of the Ministry of Education that the ENADE is designed to “assess the students' performance of undergraduate, freshmen and graduating, in relation to the program content of the courses in which they are enrolled " (Instituto Nacional de Estudos e Pesquisas Educacionais Anísio Teixeira (INEP), 2015).

Some critics extend this argument further. Leite (2010) argues that the implementation of the ENADE, and its predecessor Provão are neoclassical tools to measure and evaluate institutions through student outcomes. She reasons that instead, institutions should focus on cognitive, socio, and political activities to encourage educational development and growth instead of creating "student-consumers" (Leite, 2010, p.23).

The study aimed to evaluate academic achievements of the quota-admitted population in federal universities in Brazil. Despite its shortcoming, the ENADE remains the only viable proxy to answer the research questions of this study.

\section{Implications}

While significant and thought-provoking, this study contributes to the literature in four ways. First, it extends student development theories that have previously not been 
applied to Brazilian university students. It supports the notion that social support while facing challenges, connection to campus through paid engagement (the variable in this study was called academic involvement scholarship), and increased studying hours are all associated with higher ENADE exam scores. Using Astin’s (1993) I-E-O model, this study controlled for inputs to more precisely measure the impact of the environment on performance of students who enrolled through quota. On the other hand, it questions Astin's model's efficacy in this new population. The I-E-O model used in this dissertation was comprehensive in its use of 27 variables that are used to measure students' success; however, the full model only explained $10 \%$ of the variance in scores.

Second, it provides information to university administrations and policymakers regarding the impact of retention programs, social support networks, and programs that are working to benefit students' performance. On the one hand, academic involvement scholarship had a positive impact on performance and these opportunities should be expanded and further encouraged for quota-students. Other retention services such as housing and meal stipends were not as impactful as hypothesized in the study. This result is not to be interpreted as indicating that these programs are not effective, but that additional investigation is required. Perhaps more aid is required, and the threshold at which aid is received is not enough.

Penultimately, it highlights the need to accept and evaluate success of students who enrolled through quota in its merit. Previous studies have aimed to legitimize students who enrolled though quota by highlighting or proving their academic worth in higher education through the comparison of performance with the non-quota system. The aim of this study was also to provide a shift in perspective and to look at quota-students' 
success and understand the factors that can continue to ensure their success in higher education. The purpose of the Law of Social Quotas is to expand access to a traditionally underrepresented sector of the Brazilian population. The notion that we must do that while holding the idea that higher education is a meritocracy goes against the openness in the spirit of the law.

Finally, it calls into question the ENADE exam and its ability to assess student learning. Critics of the exam have pointed to flaws in this inception and structure (Leite, 2010; Schwartzman, 2005). This study further questions the fact that inclusion of comprehensive variables explained only $10 \%$ of the variance in scores.

Implications for practice. The impact on policy and practice have been mentioned in the preceding paragraphs and incorporated in the findings and discussion sections. In this section, I will directly and briefly refer to them. This study located 13 significant predictors of student success using Astin's I-E-O model (1993). Four predictors emerged from the environment section of the study, i.e., after controlling for inputs and the bridge block. The first of these variables is academic involvement scholarship. College students who engaged in academically focused projects with monetary remuneration that have been described in this study as academic involvement scholarship scored higher in the ENADE exam after controlling for certain variables. Policymakers should increase funds and expand these opportunities for all quota-admitted students. University administrators should continue to promote and engage students in similar opportunities and use these data to support calls for additional funding.

Social support was the next variable to be significantly associated with increased performance on the ENADE exam score with a beta weight of 0.04 . The received social 
support while facing a challenge variable measured whether a student who faced challenges received or did not receive support. The findings suggest that students who receive social support may have experienced a buffering effect or shield, and thus showed better performance than those who did not. University administrators should promote support networks for students within the university by creating an environment that is supportive of quota-students. One approach can be to emulate the services developed in the United States for Hispanic and Black students.

The last two variables to be key predictors of quota-success were in the individual student involvement block. These included the number of hours spent studying and reading for pleasure. These findings, while expected, are not easily transformed into practical recommendations. University administrators and faculty should reiterate the importance of studying outside of class. The faculty and institutional support variable was not impactful in this study, and more emphasis and research are required to identify the relationship between faculty interaction and success of students who enrol through quota.

Implications for policy. Within the input blocks, the following: the personal and family characteristics of quota-admitted students, being young, male, White, and having higher family income were all associated with higher ENADE scores. Together, these variables explained $5.2 \%$ of the variance in scores. The full model explains $10 \%$ of the variance with 26 variables, which is a low number. Policymakers should be concerned that the ENADE exam may not, in fact, be a good measure of students' success. Viable alternatives need to be researched and have been discussed below. 
Policymakers should invest in academic involvement scholarships and seek more guidance from university administrators about their effectiveness on campuses beyond the generalized findings of this study. A few studies (Bezzera, 2010; Cardoso, 2008; Childs \& Stromquist, 2015) have demonstrated that quota students have a lower attrition rate than non-quota students. It seems that these opportunities are generally offered to quota-students and perhaps there is an opportunity to open it up to general students as well to improve the attrition of non-quota students.

More broadly, given the large number of White students in the study (40\%), policymakers should re-evaluate the aims of the law of social quota and consider race as a criterion if the program aims to expand access to students who have been traditionally excluded from higher education. Given the geopolitical context this, while necessary, seems unlikely to happen. Jair Bolsonaro, the new Brazilian President, has publicly stated that he believes the federal university quota system is causing a division in Brazil and he plans to reduce the percentage currently allotted by law (Antunes, 2018).

\section{Recommendations for Future Research}

A chief limitation of this study is the inability to control for previous academic achievements, a significant predictor of students' success in college (Astin, 1993). Grade point average and standardized tests in a U.S. study of Black students majoring in STEM fields, for example, can predict 17\% of the variance in college GPA (Gipson, 2016). Given the findings of this study, a future study should strive to account for the preacademic ability of quota-admitted students to determine if similar findings as the ones identified in this study emerge and if the predictive model explains more than $10 \%$ of the variance. More studies should employ Astin's Theory of Student Involvement, and I-E-O 
model to further investigate the applicability of this theoretical model and framework in Brazilian students. Particularly, given that in this study the environment as a whole did not explain enough of the variance in the academic performance of quota-admitted students as hypothesized given the broad and inclusive variables included in the model.

While this study focused on successful students who earned a college degree, future researchers should consider investigating the role of the predictor variables on students who persist as compared to those who drop out. Given the substantial number of quota students who benefited from academic involvement scholarships, policymakers should continue to devote resources to these programs. A future study on the qualitative benefits of these programs should be undertaken and focus on quota-admitted students' experiences to understand the lived experience of the students and evaluate the process of obtaining such a scholarship. 


\section{Appendix A: ENADE Socioeconomic Survey Construct Scale used in Analysis}

\begin{tabular}{|c|c|}
\hline \multirow{2}{*}{$\begin{array}{l}\text { Institutional/Faculty Support (1-6 scale, strongly } \\
\text { disagree -1, strongly agree- } 6) \\
\qquad \begin{array}{l}\text { Faculty-student relationships throughout } \\
\text { the course stimulated you to study and } \\
\text { learn. }\end{array}\end{array}$} & \\
\hline & Qe37 \\
\hline $\begin{array}{l}\text { Faculty members were available to assist } \\
\text { students outside of class time. }\end{array}$ & Qe56 \\
\hline $\begin{array}{l}\text { There were opportunities for students to } \\
\text { overcome difficulties related to the training } \\
\text { process. }\end{array}$ & Qe40 \\
\hline $\begin{array}{l}\text { The institution had sufficient staff for } \\
\text { administrative and academic support }\end{array}$ & Qe59 \\
\hline $\begin{array}{l}\text { The institution provided tutoring services } \\
\text { to assist students. }\end{array}$ & Qe60 \\
\hline $\begin{array}{l}\text { The academic activities developed inside } \\
\text { and outside the classroom made possible } \\
\text { reflection, coexistence, and respect for } \\
\text { diversity. }\end{array}$ & Qe66 \\
\hline $\begin{array}{l}\text { The institution promoted activities of } \\
\text { culture, leisure, and social interaction. }\end{array}$ & Qe67 \\
\hline
\end{tabular}




\title{
Appendix B: Socioeconomic Survey 2016 (Portuguese)
}

\author{
Ministério da Educação \\ Instituto Nacional de Estudos e Pesquisas Educacionais Anísio Teixeira \\ Diretoria de Avaliação da Educação Superior
}

Coordenação-Geral do Exame Nacional de Desempenho dos Estudantes

QUESTIONÁRIO DO ESTUDANTE 2016

Caro (a) estudante,

Este questionário constitui um instrumento importante para compor o perfil socioeconômico e acadêmico dos participantes do Enade e uma oportunidade para você avaliar diversos aspectos do seu curso e formação.

Sua contribuição é extremamente relevante para melhor conhecermos como se constrói a qualidade da educação superior no pais. As respostas às questões serão analisadas em conjunto, preservando o sigilo da identidade dos participantes.

Para responder, basta clicar sobre a alternativa desejada. No final de cada página, ao pressionar um dos botões "Próximo" ou "Anterior", o sistema gravará a resposta no banco de dados, que poderá ser modificada a qualquer tempo. O questionário será enviado ao Inep apenas quando, na última página, for acionado o botão "Finalizar", indicando o preenchimento total do questionário. Ao final, será possivel visualizar seu local e horário da prova.

Agradecemos a sua colaboraçãol

1. Qual o seu estado civil?
A ( ) Solteiro(a).
B ( ) Casado(a).
C ( ) Separado(a) judicialmente/divorciado(a).
D ( ) Viúvo(a).
E ( ) Outro.

2. Qual é a sua cor ou raça?

A () Branca.

B ( ) Preta.

C ( ) Amarela.

D ( ) Parda.

E ( ) Indígena.

F ( ) Não quero declarar.

3. Qual a sua nacionalidade?

A () Brasileira.

B ( ) Brasileira naturalizada.

C ( ) Estrangeira.

4. Até que etapa de escolarização seu pai concluiu?

A ( ) Nenhuma.

B ( ) Ensino Fundamental: 10 ao 50 ano (1a a 4a série)

C ( Ensino Fundamental: 6ㅇ ao 90 ano (5a a $8^{a}$ série)

D ( ) Ensino Médio.

E ( ) Ensino Superior - Graduação.

F ( ) Pós-graduação.

5. Até que etapa de escolarização sua mãe concluiu?

A ( ) Nenhuma.

B ( Ensino fundamental: $1^{\circ}$ ao $5^{\circ}$ ano (1a a $4^{\mathrm{a}}$ série). 
C ( ) Ensino fundamental: 6ㅇ ao $9^{\circ}$ ano (5a a $8^{\text {a }}$ série).

D ( ) Ensino médio.

E ( ) Ensino Superior - Graduação.

F ( ) Pós-graduação.

6. Onde e com quem você mora atualmente?

A ( ) Em casa ou a partamento, sozinho.

B ( ) Em casa ou apartamento, com pais e/ou parentes.

C ( ) Em casa ou apartamento, com cônjuge e/ou filhos.

D ( ) Em casa ou apartamento, com outras pessoas (incluindo república).

E ( ) Em alojamento universitário da própria instituição.

F ( ) Em outros tipos de habitação individual ou coletiva (hotel, hospedaria, pensão ou outro).

7. Quantas pessoas da sua família moram com você? Considere seus pais, irmãos, cônjuge, filhos e outros parentes que moram na mesma casa com você.
A ( ) Nenhuma.
B () Uma.
C ( ) Duas.
D $($ ) Três.
E ( ) Quatro.
F ( ) Cinco.
G ( ) Seis.
H ( ) Sete ou mais.

8. Qual a renda total de sua família, incluindo seus rendimentos?
A ( ) Até 1,5 salário mínimo (até R\$1.320,00)
B () De 1,5 a 3 salários mínimos (R\$ 1.320,01 a $\mathrm{R} \$ 2.640,00$ ).
C ( ) De 3 a 4,5 salários mínimos ( $R \$ 2.640,01$ a $\mathrm{R} \$ 3.960,00$ ).
D ( ) De 4,5 a 6 salários mínimos ( $R \$ 3.960,01$ a $R \$ 5.280,00)$.
E ( ) De 6 a 10 salários mínimos (R\$ 5.280,01 a R\$ 8.800,00).
F ( De 10 a 30 salários mínimos (R\$ 8.800,01 a R\$26.400,00).
$\mathrm{G}$ ( ) Acima de 30 salários mínimos (mais de R\$ 26.400,00).

9. Qual alternativa a seguir melhor descreve sua situação financeira (incluindo bolsas)?

A () Não tenho renda e meus gastos são financiados por programas governamentais.

B ( ) Não tenho renda e meus gastos são financiados pela minha família ou por outras pessoas.

C ( Tenho renda, mas recebo ajuda da família ou de outras pessoas para financiar meus gastos.

D ( ) Tenho renda e não preciso de ajuda para financiar meus gastos.

E ( Tenho renda e contribuo com o sustento da família.

F ( ) Sou o principal responsável pelo sustento da família.

10. Qual alternativa a seguir melhor descreve sua situação de trabalho (exceto estágio ou bolsas)?
A ( ) Não estou trabalhando.
B () Trabalho eventualmente.
C ( ) Trabalho até 20 horas semanais.
D ( ) Trabalho de 21 a 39 horas semanais.
E () Trabalho 40 horas semanais ou mais.

11. Que tipo de bolsa de estudos ou financiamento do curso você recebeu para custear todas ou a maior parte das mensalidades? No caso de haver mais de uma opção, marcar apenas a bolsa de maior duração.

A ( ) Nenhum, pois meu curso é gratuito.

B ( ) Nenhum, embora meu curso não seja gratuito.

C ( ) Prouni integral.

D ( ) ProUni parcial, apenas.

E ( ) FIES, apenas.

F ( ) ProUni Parcial e FIES

G ( Bolsa oferecida por governo estadual, distrital ou municipal. 
H ( ) Bolsa oferecida pela própria instituição.

I ( ) Bolsa oferecida por outra entidade (empresa, ONG, outra).

J () Financiamento oferecido pela própria instituição.

K ( ) Financiamento bancário.

12. Ao longo da sua trajetória acadêmica, você recebeu algum tipo de auxílio permanência? No caso de haver mais de uma opção, marcar apenas a bolsa de maior duração.

A $($ ) Nenhum.

B ( ) Auxílio moradia.

C ( ) Auxílio alimentação.

D () Auxílio moradia e alimentação.

E ( ) Auxílio permanência.

F ( ) Outro tipo de auxílio.

13. Ao longo da sua trajetória acadêmica, você recebeu algum tipo de bolsa acadêmica? No caso de haver mais de uma opção, marcar apenas a bolsa de maior duração.

A $($ ) Nenhum

B ( ) Bolsa de iniciação científica.

C ( ) Bolsa de extensão.

D ( ) Bolsa de monitoria/tutoria.

E ( ) Bolsa PET.

F ( ) Outro tipo de bolsa acadêmica.

14. Durante o curso de graduação você participou de programas e/ou atividades curriculares no exterior?

A ( ) Não participei.

B ( ) Sim, Programa Ciência sem Fronteiras.

C ( ) Sim, programa de intercâmbio financiado pelo Governo Federal (Marca; Brafitec; PLI; outro).

D ( ) Sim, programa de intercâmbio financiado pelo Governo Estadual.

E ( ) Sim, programa de intercâmbio da minha instituição.

F ( ) Sim, outro intercâmbio não institucional.

15. Seu ingresso no curso de graduação se deu por meio de políticas de ação afirmativa ou inclusão social?

A ( ) Não.

B ( ) Sim, por critério étnico-racial.

C ( ) Sim, por critério de renda.

D ( ) Sim, por ter estudado em escola pública ou particular com bolsa de estudos.

E ( ) Sim, por sistema que combina dois ou mais critérios anteriores.

F ( ) Sim, por sistema diferente dos anteriores.

16. Em que unidade da Federação você concluiu o ensino médio?

\begin{tabular}{|c|c|c|c|c|}
\hline()$A C$ & ( ) DF & ( ) MT & ()$R J$ & $($ ) SE \\
\hline ( ) AL & ( ) ES & ( ) PA & ( ) RN & $($ ) SP \\
\hline ( ) AM & $11 \mathrm{GO}$ & ( ) PB & ( ) RO & ( ) TO \\
\hline ( ) AP & ( ) MA & ( ) PE & $($ ) RR & ( ) Não se aplica \\
\hline ( ) BA & ( ) MG & ( ) PI & () $\mathrm{RS}$ & \\
\hline ( ) CE & ( ) MS & ( ) PR & $(1) S C$ & \\
\hline
\end{tabular}

17. Em que tipo de escola você cursou o ensino médio?
A ( ) Todo em escola pública.
B ( ) Todo em escola privada (particular).
C ( ) Todo no exterior.
D ( ) A maior parte em escola pública.
E ( A maior parte em escola privada (particular).
F ( ) Parte no Brasil e parte no exterior.

18. Qual modalidade de ensino médio você concluiu?

A () Ensino médio tradicional. 
B ( ) Profissionalizante técnico (eletrônica, contabilidade, agrícola, outro).

C ( ) Profissionalizante magistério (Curso Normal).

D ( ) Educação de Jovens e Adultos (EJA) e/ou Supletivo.

E ( ) Outra modalidade.

19. Quem Ihe deu maior incentivo para cursar a graduação?

A $($ ) Ninguém.

B ( ) Pais.

C ( ) Outros membros da família que não os pais.

D ( ) Professores.

E ( ) Líder ou representante religioso.

F ( ) Colegas/Amigos.

G () Outras pessoas.

20. Algum dos grupos abaixo foi determinante para você enfrentar dificuldades durante seu curso superior e concluí-lo?

A ( ) Não tive dificuldade.

B ( ) Não recebi apoio para enfrentar dificuldades.

C ( ) Pais.

D ( ) Avós.

E ( ) Irmãos, primos ou tios.

F ( ) Líder ou representante religioso.

G ( ) Colegas de curso ou amigos.

H ( ) Professores do curso.

I () Profissionais do serviço de apoio ao estudante da IES.

J ( ) Colegas de trabalho.

K () Outro grupo.

21. Alguém em sua família concluiu um curso superior?

A $($ ) Sim.

B () Não.

22. Excetuando-se os livros indicados na bibliografia do seu curso, quantos livros você leu neste ano?
A ( ) Nenhum.
B ( ) Um ou dois.
C ( ) De três a cinco.
D ( ) De seis a oito.
E ( ) Mais de oito.

23. Quantas horas por semana, aproximadamente, você dedicou aos estudos, excetuando as horas de aula?

A ( ) Nenhuma, apenas assisto às aulas.

B ( ) De uma a três.

C ( ) De quatro a sete.

D ( ) De oito a doze.

E ( ) Mais de doze.

24. Você teve oportunidade de aprendizado de idioma estrangeiro na Instituição?

A $($ ) Sim, somente na modalidade presencial.

B ( ) Sim, somente na modalidade semipresencial.

C ( ) Sim, parte na modalidade presencial e parte na modalidade semipresencial.

D () Sim, na modalidade a distância.

E ( ) Não.

25. Qual o principal motivo para você ter escolhido este curso?

A () Inserção no mercado de trabalho.

B ( ) Influência familiar.

C () Valorização profissional. 
D ( ) Prestigio Social.

E ( ) Vocação.

F ( ) Oferecido na modalidade a distância.

G ( ) Baixa concorrência para ingresso.

H ( ) Outro motivo.

26. Qual a principal razão para você ter escolhido a sua instituição de educação superior? A ( ) Gratuidade.

B ( ) Preço da mensalidade.

C ( ) Proximidade da minha residência.

D () Proximidade do meu trabalho.

E ( ) Facilidade de acesso.

F ( ) Qualidade/reputação.

G ( ) Foi a única onde tive aprovação.

H () Possibilidade de ter bolsa de estudo.

I ( ) Outro motivo. 
A seguir, leia cuidadosamente cada assertiva e indique seu grau de concordância com cada uma delas, segundo a escala que varia de 1 (discordância total) a 6 (concordância total). Caso você julgue não ter elementos para avaliar a assertiva, assinale a opção "Não sei responder" e, quando considerar não pertinente ao seu curso, assinale "Não se aplica".

\begin{tabular}{|c|c|c|c|c|c|c|c|}
\hline $\begin{array}{c}\text { ORGANIZACCÃO DIDÁTICO-PEDAGÓGICA/INFRAESTRUTURA E } \\
\text { INSTALAÇ̃̃ES FíSICAS/OPORTUNIDADES DE AMPLIAÇÃO DA } \\
\text { FORMAÇÃO ACADÊMICA E PROFISSIONAL }\end{array}$ & $\begin{array}{l}1 \bigcirc \text { Discordo } \\
\text { Totalmente }\end{array}$ & 20 & 30 & 40 & 50 & $\begin{array}{l}60 \text { Concordo } \\
\text { Totalmente }\end{array}$ & \\
\hline \begin{tabular}{|l}
$\begin{array}{l}\text { 27. As disciplinas cursadas contribuíram para sua formação } \\
\text { integral, como cidadão e profissional. }\end{array}$ \\
\end{tabular} & 10 & 20 & $3 \bigcirc$ & 40 & 50 & 60 & $\begin{array}{l}\text { ( ) Não sei responder } \\
\text { ( ) Não se aplica }\end{array}$ \\
\hline $\begin{array}{l}28 . \text { Os conteúdos abordados nas disciplinas do curso } \\
\text { favoreceram sua atuação em estágios ou em atividades de } \\
\text { iniciação profissional. }\end{array}$ & 10 & 20 & 30 & $4 \bigcirc$ & $5 \bigcirc$ & 60 & $\begin{array}{l}\text { ( ) Não sei responder } \\
\text { ( ) Não se aplica }\end{array}$ \\
\hline $\begin{array}{l}\text { 29. As metodologias de ensino utilizadas no curso desafiaram } \\
\text { você a aprofundar conhecimentos e desenvolver } \\
\text { competências reflexivas e criticas. }\end{array}$ & 10 & 20 & 30 & 40 & 50 & 60 & $\begin{array}{l}\text { () Não sei responder } \\
\text { () Não se aplica }\end{array}$ \\
\hline 30.0 curso propiciou experiências de aprendizagem inovadoras. & 10 & 20 & 30 & $4 \bigcirc$ & 50 & 60 & $\begin{array}{l}\text { ( ) Não sei responder } \\
\text { ( ) Não se aplica }\end{array}$ \\
\hline $\begin{array}{l}31.0 \text { curso contribuiu para o desenvolvimento da sua } \\
\text { consciência ética para o exercício profissional. }\end{array}$ & 10 & 20 & 30 & $4 \bigcirc$ & 50 & 60 & $\begin{array}{l}\text { () Não sei responder } \\
\text { ( ) Não se aplica }\end{array}$ \\
\hline $\begin{array}{l}\begin{array}{l}\text { 32. No curso você teve oportunidade de aprender a trabalhar em } \\
\text { equipe. }\end{array} \\
\end{array}$ & 10 & 20 & 30 & $4 \bigcirc$ & $5 \bigcirc$ & 60 & $\begin{array}{l}\text { ( ) Não sei responder } \\
\text { ( ) Não se aplica }\end{array}$ \\
\hline $\begin{array}{l}\text { 33. O curso possibilitou aumentar sua capacidade de reflexão e } \\
\text { argumentação. }\end{array}$ & 10 & 20 & 30 & 40 & 50 & 60 & $\begin{array}{l}\text { ( ) Não sei responder } \\
\text { ( ) Não se aplica }\end{array}$ \\
\hline $\begin{array}{l}\text { 34. O curso promoveu o desenvolvimento da sua capacidade de } \\
\text { pensar criticamente, analisar e refletir sobre soluçōes para } \\
\text { problemas da sociedade. }\end{array}$ & 10 & 20 & 30 & $4 \bigcirc$ & 50 & 60 & $\begin{array}{l}\text { ( ) Não sei responder } \\
\text { ( ) Não se aplica }\end{array}$ \\
\hline $\begin{array}{l}\begin{array}{l}35.0 \text { curso contribuiu para você ampliar sua capacidade de } \\
\text { comunicação nas formas oral e escrita. }\end{array} \\
\end{array}$ & 10 & $2 \bigcirc$ & 30 & 40 & 50 & 60 & $\begin{array}{l}\text { ( ) Não sei responder } \\
\text { ( ) Não se aplica } \\
\end{array}$ \\
\hline $\begin{array}{l}36.0 \text { curso contribuiu para o desenvolvimento da sua } \\
\text { capacidade de aprender e atualizar-se permanentemente. }\end{array}$ & 10 & 20 & 30 & $4 \bigcirc$ & 50 & 60 & $\begin{array}{l}\text { () Não sei responder } \\
\text { () Não se aplica }\end{array}$ \\
\hline $\begin{array}{l}\text { 37. As relações professor-aluno ao longo do curso estimularam } \\
\text { você a estudar e aprender. }\end{array}$ & 10 & 20 & $3 \bigcirc$ & $4 \bigcirc$ & $5 \bigcirc$ & 60 & $\begin{array}{l}\text { () Não sei responder } \\
\text { ( ) Não se aplica }\end{array}$ \\
\hline $\begin{array}{l}\text { 38. Os planos de ensino apresentados pelos professores } \\
\text { contribuiram para o desenvolvimento das atividades } \\
\text { acadêmicas e para seus estudos. }\end{array}$ & 10 & 20 & 30 & 40 & $5 \bigcirc$ & 60 & $\begin{array}{l}\text { () Não sei responder } \\
\text { () Não se aplica }\end{array}$ \\
\hline
\end{tabular}




\begin{tabular}{|c|c|c|c|c|c|c|c|}
\hline $\begin{array}{l}\text { 39. As referências bibliográficas indicadas pelos professores nos } \\
\text { planos de ensino contribuíram para seus estudos e } \\
\text { aprendizagens. }\end{array}$ & 10 & 20 & $3 \bigcirc$ & $4 \bigcirc$ & 50 & 60 & $\begin{array}{l}\text { ( ) Não sei responder } \\
\text { () Não se aplica }\end{array}$ \\
\hline $\begin{array}{l}\text { 40. Foram oferecidas oportunidades para os estudantes } \\
\text { superarem dificuldades relacionadas ao processo de } \\
\text { formação. }\end{array}$ & $1 \bigcirc$ & 20 & $3 \bigcirc$ & $4 \bigcirc$ & $5 \bigcirc$ & 60 & $\begin{array}{l}\text { () Não sei responder } \\
\text { () Não se aplica }\end{array}$ \\
\hline $\begin{array}{l}\text { 41. A coordenação do curso esteve disponivel para orientação } \\
\text { acadêmica dos estudantes. }\end{array}$ & $1 \bigcirc$ & 20 & 30 & 40 & 50 & 60 & $\begin{array}{l}\text { ( ) Não sei responder } \\
\text { ( ) Não se aplica }\end{array}$ \\
\hline $\begin{array}{l}\text { 42. O curso exigiu de você organização e dedicação frequente aos } \\
\text { estudos. }\end{array}$ & $1 \bigcirc$ & 20 & $3 \bigcirc$ & $4 \bigcirc$ & $5 \bigcirc$ & $6 \bigcirc$ & $\begin{array}{l}\text { () Não sei responder } \\
\text { () Não se aplica }\end{array}$ \\
\hline $\begin{array}{l}\text { 43. Foram oferecidas oportunidades para os estudantes } \\
\text { participarem de programas, projetos ou atividades de } \\
\text { extensão universitária. }\end{array}$ & 10 & 20 & 30 & $4 \bigcirc$ & $5 \bigcirc$ & 60 & $\begin{array}{l}\text { ( ) Não sei responder } \\
\text { ( ) Não se aplica }\end{array}$ \\
\hline $\begin{array}{l}\text { 44. Foram oferecidas oportunidades para os estudantes } \\
\text { participarem de projetos de iniciação científica e de } \\
\text { atividades que estimularam a investigação acadêmica. }\end{array}$ & $1 \bigcirc$ & 20 & $3 \bigcirc$ & $4 \bigcirc$ & 50 & 60 & $\begin{array}{l}\text { () Não sei responder } \\
\text { ( ) Não se aplica }\end{array}$ \\
\hline $\begin{array}{l}\text { 45. O curso ofereceu condiç̃es para os estudantes participarem } \\
\text { de eventos internos e/ou externos à instituição. }\end{array}$ & 10 & 20 & 30 & 40 & 50 & 60 & $\begin{array}{l}\text { () Não sei responder } \\
\text { () Não se aplica }\end{array}$ \\
\hline $\begin{array}{l}\text { 46. A instituição ofereceu oportunidades para os estudantes } \\
\text { atuarem como representantes em órgãos colegiados. }\end{array}$ & 10 & 20 & 30 & $4 \bigcirc$ & 50 & 60 & $\begin{array}{l}\text { () Não sei responder } \\
\text { () Não se aplica }\end{array}$ \\
\hline $\begin{array}{l}\text { 47. o curso favoreceu a articulação do conhecimento teórico } \\
\text { com atividades práticas. }\end{array}$ & 10 & 20 & 30 & 40 & 50 & 60 & $\begin{array}{l}\text { () Não sei responder } \\
\text { ( ) Não se aplica }\end{array}$ \\
\hline $\begin{array}{l}\text { 48. As atividades práticas foram suficientes para relacionar os } \\
\text { conteúdos do curso com a prática, contribuindo para sua } \\
\text { formação profissional. }\end{array}$ & $1 \bigcirc$ & 20 & 30 & $4 \bigcirc$ & $5 \bigcirc$ & 60 & $\begin{array}{l}\text { () Não sei responder } \\
\text { ( ) Não se aplica }\end{array}$ \\
\hline $\begin{array}{l}\text { 49. O curso propiciou acesso a conhecimentos atualizados e/ou } \\
\text { contemporâneos em sua área de formação. }\end{array}$ & 10 & 20 & 30 & $4 \bigcirc$ & 50 & 60 & $\begin{array}{l}\text { ( ) Não sei responder } \\
\text { ( ) Não se aplica }\end{array}$ \\
\hline $\begin{array}{l}50.0 \text { estágio supervisionado proporcionou experiências } \\
\text { diversificadas para a sua formação. }\end{array}$ & $1 \bigcirc$ & 20 & 30 & $4 \bigcirc$ & 50 & 60 & $\begin{array}{l}\text { ( ) Não sei responder } \\
\text { ( ) Não se aplica }\end{array}$ \\
\hline $\begin{array}{l}\text { 51. As atividades realizadas durante seu trabalho de conclusão } \\
\text { de curso contribuíram para qualificar sua formação } \\
\text { profissional }\end{array}$ & $1 \bigcirc$ & 20 & $3 \bigcirc$ & $4 \bigcirc$ & $5 \bigcirc$ & 60 & $\begin{array}{l}\text { ( ) Não sei responder } \\
\text { ( ) Não se aplica }\end{array}$ \\
\hline $\begin{array}{l}\text { 52. Foram oferecidas oportunidades para os estudantes } \\
\text { realizarem intercâmbios e/ou estágios no pais. }\end{array}$ & $1 \bigcirc$ & 20 & 30 & $4 \bigcirc$ & $5 \bigcirc$ & 60 & $\begin{array}{l}\text { () Não sei responder } \\
\text { () Não se aplica }\end{array}$ \\
\hline $\begin{array}{l}\text { 53. Foram oferecidas oportunidades para os estudantes } \\
\text { realizarem intercâmbios e/ou estágios fora do pais. }\end{array}$ & 10 & 20 & 30 & $4 \bigcirc$ & $5 \bigcirc$ & 60 & $\begin{array}{l}\text { ( ) Não sei responder } \\
\text { ( ) Não se aplica }\end{array}$ \\
\hline
\end{tabular}




\begin{tabular}{|c|c|c|c|c|c|c|c|}
\hline \begin{tabular}{|l|}
$\begin{array}{l}\text { 54. Os estudantes participaram de avaliações periódicas do curso } \\
\text { (disciplinas, atuação dos professores, infraestrutura). }\end{array}$ \\
\end{tabular} & $1 \bigcirc$ & 20 & $3 \bigcirc$ & $4 \bigcirc$ & $5 \bigcirc$ & 60 & $\begin{array}{l}\text { ( ) Não sei responder } \\
\text { ( ) Não se aplica }\end{array}$ \\
\hline $\begin{array}{l}\text { 55. As avaliações da aprendizagem realizadas durante o curso } \\
\text { foram compativeis com os conteúdos ou temas trabalhados } \\
\text { pelos professores. }\end{array}$ & 10 & 20 & 30 & 40 & 50 & 60 & $\begin{array}{l}\text { ( ) Não sei responder } \\
\text { ( ) Não se aplica }\end{array}$ \\
\hline $\begin{array}{l}\text { 56. Os professores apresentaram disponibilidade para atender os } \\
\text { estudantes fora do horário das aulas. }\end{array}$ & 10 & 20 & 30 & $4 \bigcirc$ & 50 & 60 & $\begin{array}{l}\text { ( ) Não sei responder } \\
\text { ( ) Não se aplica }\end{array}$ \\
\hline $\begin{array}{l}\begin{array}{l}57.0 s \text { professores demonstraram domínio dos conteúdos } \\
\text { abordados nas disciplinas. }\end{array} \\
\end{array}$ & 10 & 20 & 30 & $4 \bigcirc$ & 50 & 60 & $\begin{array}{l}\text { ( ) Não sei responder } \\
\text { ( ) Não se aplica }\end{array}$ \\
\hline $\begin{array}{l}\text { 58. Os professores utilizaram tecnologias da informação e } \\
\text { comunicação (TICs) como estratégia de ensino (projetor } \\
\text { multimídia, laboratório de informática, ambiente virtual de } \\
\text { aprendizagem). }\end{array}$ & $1 \bigcirc$ & 20 & $3 \bigcirc$ & $4 \bigcirc$ & $5 \bigcirc$ & 60 & $\begin{array}{l}\text { ( ) Não sei responder } \\
\text { ( ) Não se aplica }\end{array}$ \\
\hline $\begin{array}{l}\text { 59. A instituição dispôs de quantidade suficiente de funcionários } \\
\text { para o apoio administrativo e acadêmico. }\end{array}$ & 10 & 20 & 30 & $4 \bigcirc$ & 50 & 60 & $\begin{array}{l}\text { ( ) Não sei responder } \\
\text { ( ) Não se aplica }\end{array}$ \\
\hline $\begin{array}{l}60.0 \text { curso disponibilizou monitores ou tutores para auxiliar os } \\
\text { estudantes. }\end{array}$ & 10 & 20 & 30 & $4 \bigcirc$ & 50 & 60 & $\begin{array}{l}\text { () Não sei responder } \\
\text { ( ) Não se aplica }\end{array}$ \\
\hline $\begin{array}{l}\text { 61. As condições de infraestrutura das salas de aula foram } \\
\text { adequadas. }\end{array}$ & 10 & 20 & 30 & $4 \bigcirc$ & 50 & 60 & $\begin{array}{l}\text { () Não sei responder } \\
\text { ( ) Não se aplica }\end{array}$ \\
\hline \begin{tabular}{|c|} 
62. Os equipamentos e materiais disponiveis para as aulas \\
práticas foram adequados para a quantidade de estudantes.
\end{tabular} & 10 & 20 & $3 \bigcirc$ & $4 \bigcirc$ & $5 \bigcirc$ & 60 & $\begin{array}{l}\text { ( ) Não sei responder } \\
\text { ( ) Não se aplica }\end{array}$ \\
\hline $\begin{array}{l}\text { 63. Os ambientes e equipamentos destinados às aulas práticas } \\
\text { foram adequados ao curso. }\end{array}$ & 10 & 20 & 30 & $4 \bigcirc$ & 50 & 60 & $\begin{array}{l}\text { () Não sei responder } \\
\text { () Não se aplica }\end{array}$ \\
\hline $\begin{array}{l}\text { 64. A biblioteca dispôs das referências bibliográficas que os } \\
\text { estudantes necessitaram. }\end{array}$ & 10 & 20 & 30 & $4 \bigcirc$ & 50 & 60 & $\begin{array}{l}\text { ( ) Não sei responder } \\
\text { () Não se aplica }\end{array}$ \\
\hline \begin{tabular}{|l|} 
65. A instituição contou com biblioteca virtual ou conferiu acesso \\
a obras disponiveis em acervos virtuais.
\end{tabular} & 10 & 20 & $3 \bigcirc$ & $4 \bigcirc$ & 50 & 60 & $\begin{array}{l}\text { ( ) Não sei responder } \\
\text { ( ) Não se aplica }\end{array}$ \\
\hline $\begin{array}{l}\text { 66. As atividades acadêmicas desenvolvidas dentro e fora da sala } \\
\text { de aula possibilitaram reflexão, convivência e respeito à } \\
\text { diversidade. }\end{array}$ & $1 \bigcirc$ & 20 & 30 & $4 \bigcirc$ & 50 & 60 & $\begin{array}{l}\text { ( ) Não sei responder } \\
\text { ( ) Não se aplica }\end{array}$ \\
\hline $\begin{array}{l}\text { 67. A instituição promoveu atividades de cultura, de lazer e de } \\
\text { interação social. }\end{array}$ & 10 & 20 & 30 & $4 \bigcirc$ & 50 & 60 & $\begin{array}{l}\text { ( ) Não sei responder } \\
\text { ( ) Não se aplica }\end{array}$ \\
\hline $\begin{array}{l}\text { 68. A instituição dispôs de refeitório, cantina e banheiros em } \\
\text { condições adequadas que atenderam as necessidades dos } \\
\text { seus usuários. }\end{array}$ & 10 & 20 & $3 \bigcirc$ & $4 \bigcirc$ & 50 & 60 & $\begin{array}{l}\text { ( ) Não sei responder } \\
\text { ( ) Não se aplica }\end{array}$ \\
\hline
\end{tabular}




\section{Appendix C: Socioeconomic Survey 2016 Translated to English}

Ministry of Education

National Institute of Educational Studies and Research Anísio Teixeira

Higher Education Evaluation Board

General Coordination of the National Student Performance Examination

\section{STUDENT QUESTIONNAIRE 2016}

Dear student,

This questionnaire is an important tool to compose the socioeconomic and academic profile of the ENADE participants and an opportunity for you to evaluate the various aspects of your course and training.

Your contribution is extremely relevant to better understand how to improve the quality of higher education in the country. The answers to the questions will be analyzed together, preserving the confidentiality of the participants' identity.

To respond, just click on the desired alternative. At the end of each page, pressing one of the "Next" or "Previous" buttons will record the response in the database, which can be modified at any time. The questionnaire will be sent to INEP only when, on the last page, the "Finish" button is pressed, thereby indicating the complete completion of the questionnaire.

Thank you for your cooperation! 
1. What is your marital status?
A. Single
B. Married
C. Separated judicially / divorced
D. Widowed
E. Other

2. What is your color or race?
A. White
B. Black
C. Yellow
D. Brown
E. Indigenous
F. I do not want to declare

3. What is your nationality?
A. Brazilian
B. Naturalized Brazilian
C. Other

4. Up to what stage did your father complete schooling?
A. None
B. Elementary school: (1st to 4th grade).
C. Middle school: (5th to 8th grade).
D. High school
E. Bachelor's degree
F. Graduate school

5. Up to what stage did your mother complete schooling?
A. None
B. Elementary school: (1st to 4th grade).
C. Middle school: (5th to 8th grade).
D. High school
E. Bachelor's degree
F. Graduate school

6. Where and with whom do you currently live?
A. In house or apartment, alone.
B. In house or apartment, with parents and / or relatives.
C. In house or apartment, with spouse and / or children.
D. In house or apartment, with other people (including roommates)
E. On campus (university-housing)
F. In other types of individual or collective housing (hotel, hostel, pension or other).
7. How many people in your family live with you? Consider your parents, siblings, spouse, children, and other relatives who live in the same house with you. 

A. None
B. One
C. Two
D. Three
E. Four
F. Five
G. Six
H. Seven or more

8. What is the total income of your family, including your [monthly] income?
A. Up to 1.5 minimum wage (up to $\mathrm{R} \$ 1,320.00$ ). ${ }^{34}$
B. From 1.5 to 3 minimum wages ( $\mathrm{R} \$ 1,320.01$ to $\mathrm{R} \$ 2,640.00$ ).
C. From 3 to 4.5 minimum wages ( $\mathrm{R} \$ 2,640.01$ to $\mathrm{R} \$ 3,960.00$ ).
D. From 4.5 to 6 minimum wages $(\mathrm{R} \$ 3,960.01$ to $\mathrm{R} \$ 5,280.00$ ).
E. From 6 to 10 minimum wages ( $\mathrm{R} \$ 5,280.01$ to $\mathrm{R} \$ 8,800.00$ ).
F. From 10 to 30 minimum wages ( $\mathrm{R} \$ 8,800.01$ to $\mathrm{R} \$ 26,400.00$ ).
$\mathrm{G}$. Above 30 minimum wages (more than $\mathrm{R} \$ 26,400.00$ ).

9. Which of the following best describes your financial situation (including scholarships)?

A. I have no income and my expenses are funded by government programs.

B. I have no income and my expenses are funded by my family or other people.

C. I have income, but I get help from family or other people to finance my expenses.

D. I have income and do not need help to finance my expenses.

E. I have income and contribute to the family's livelihood.

F. I am primarily responsible for the family's livelihood.

10. Which alternative best describes your work situation (other than internships or scholarships)?
A. I'm not working
B. Work sometimes
C. Work up to 20 hours a week
D. Work from 21 to 39 hours a week
E. Work 40 hours a week or more

11. What type of scholarship or funding did you receive to cover all or most of the tuition? In case there is more than one option, mark only the scholarship/funding of the longer duration.
A. None, because my university is free
B. None, although my university is not free
C. ProUni integral
D. ProUni only
E. FIES, only

\footnotetext{
${ }^{34} \mathrm{R}$ represents reais for Brazilian currency. Minimum wage is measured in a monthly amount.
} 
F. ProUni Partial and FIES

G. Scholarship offered by state, district, or municipal government.

H. Institutional scholarship

I. Grant offered by another entity (company, NGO, other).

J. Financing offered by the institution itself.

$\mathrm{K}$. Bank financing.

12. Throughout your academic trajectory, have you received any kind of permanence aid? In case there is more than one option, mark only the one of longer duration.
A. None
B. Housing stipend
C. Meal stipend
D. Room and board stipend
E. Permanence aid.
F. Other type of aid.

13. Throughout your academic career, have you received any kind of scholarship? In case there is more than one option, mark only the bag of longer duration.
A None.
B Scientific initiation bag.
C Extension bag.
D Bag of monitoring / mentoring.
E PET bag.

F Another type of academic scholarship.

14. During the undergraduate course, did you participate in curricular programs and / or activities abroad?

A I did not participate.

B Yes, Science without Borders Program.

C Yes, exchange program financed by the Federal Government (Brand, Brafitec, PLI, other).

D Yes, exchange program financed by the State Government.

E Yes, my institution's exchange program.

$\mathrm{F}$ Yes, another non-institutional exchange.

15. Did you enrol in the undergraduate course through affirmative-action or social inclusion policies?

A No.

B Yes, by ethnic-racial criteria.

C Yes, by income criterion.

D Yes, for having studied in public or private school with scholarship.

E Yes, per a system that combines two or more of the previous criteria.

F Yes, by a system different from previous ones. 
16. In which unit of the state did you finish high school?

$\begin{array}{lll}\text { AC } & \text { MG } & \text { RO } \\ \text { AL } & \text { MS } & \text { RR } \\ \text { AM } & \text { MT } & \text { RS } \\ \text { AP } & \text { PA } & \text { SC } \\ \text { BA } & \text { PB } & \text { SE } \\ \text { CE } & \text { PE } & \text { SP } \\ \text { DF } & \text { PI } & \text { TO } \\ \text { ES } & \text { PR } & \text { ( ) Not applicable } \\ \text { GO } & \text { RJ } & \\ \text { MA } & \text { RN }\end{array}$

17. What kind of high school did you attend?

A All in public school.

B All in private school (private).

C All abroad.

D Most in public school.

E Most in private school (private).

F Partly in Brazil and partly abroad.

18. Which kind of high school did you complete?

A Traditional high school.

B Technical professional (electronics, accounting, agricultural, other).

C Vocational teacher training (Regular Course). ${ }^{35}$

D Youth and Adult Education (EJA) and / or Supplementary Education.

E Another modality.

19. Who gave you the most encouragement to pursue your degree?

A nobody.

B Parents.

C Other family members other than parents.

D Teachers.

E Leader or religious representative.

F Colleagues / Friends.

G Other people.

${ }^{35}$ This type of high school education that include a teacher training certification is phasing out as of 2012. 
20. Were any of the groups below decisive in helping you face difficulty situations during your college course and completing it?

A I had no difficulty.

B I did not receive support to face difficulties.

C Country.

D Grandparents.

E Brothers, cousins, or uncles.

F Leader or religious representative.

G Classmates or friends.

$\mathrm{H}$ Teachers of the course.

I Professionals of the IES student support service.

J Co-workers.

K Another group.

21. Has anyone in your family completed a college degree?

A Yes.

B No.

22. Except for the books listed in your course bibliography, how many books did you read this year?

A None.

B One or two.

C Three to five.

D Six to eight.

E More than eight.

23. How many hours per week did you dedicate to your studies, except for class hours?

A None, I just attend classes.

B One to three.

C Four to seven.

D From eight to twelve.

E More than twelve.

24. Did you have an opportunity to learn a foreign language at the institution?

A Yes, only in face-to-face mode.

B Yes, only in the mixed mode.

C Yes, part in the face-to-face mode and part in the blended mode.

D Yes, in the distance mode.

E. No opportunity available.

25. What is the main reason you chose this course?

A Insertion in the job market.

B Family influence.

C Professional value/appreciation.

D Social prestige.

E Vocation/Calling 
F Offered in distance learning.

G Low competition for admission.

$\mathrm{H}$ Another reason.

26. What is the main reason you chose your higher education institution?

A It was free.

B Cost of attendance/tuition

C Proximity to my residence.

D Proximity to my work.

E Ease of access.

F Quality/reputation.

G It was the only one where I got accepted into.

$\mathrm{H}$ Possibility of receiving scholarship.

I Another reason.

Next, carefully read each assertion and indicate your degree of agreement with each, on to a scale that ranges from 1 (total disagreement) to 6 (total agreement). If you think you do not have the elements to evaluate the assertion, check the option "I do not know how to respond" and when it is not relevant to your course, check "Not applicable".

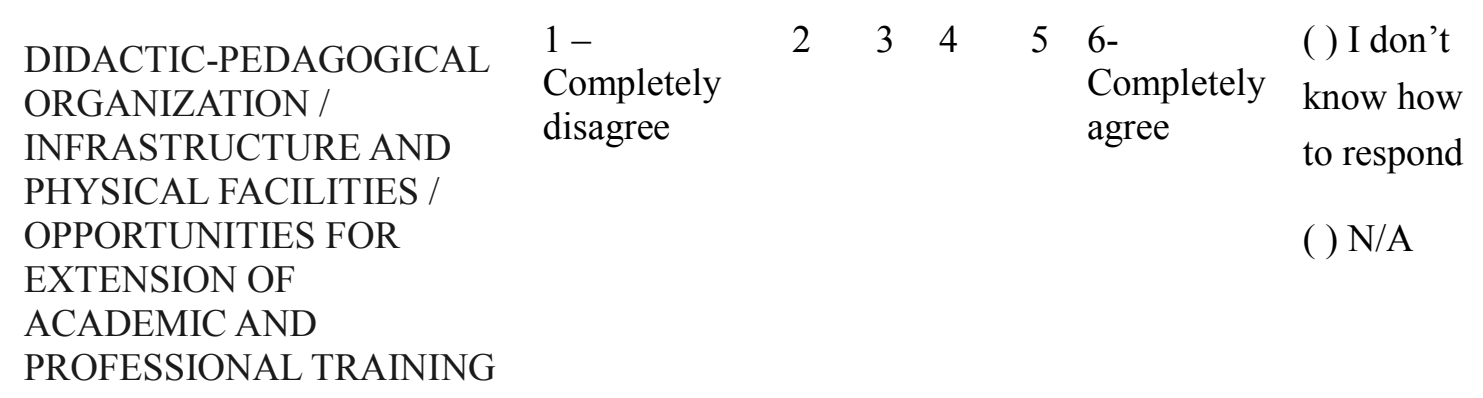

27. The subjects studied contributed to your integral development, as a citizen and professional.

28. The contents covered in the courses of the major help you in your performance in internships or in professional situations.

29. The teaching methodologies used in the major challenged you and deepened the knowledge and development of critical skills.

30. Your institution provided innovative learning experiences.

31. Your studies contributed to the development of your ethical awareness for professional practice.

32. In college, you had the opportunity to learn to work as a team. 
33. Your college experience made it possible to increase your capacity for reflection and argumentation.

34. Your major/institution promoted the development of your capacity to think critically, analyze and reflect on solutions to problems in society.

35. Your studies helped you to increase your ability to communicate in oral and written forms.

36. Your studies contributed to your development and your capacity to learn and continue learning.

37. Faculty-student relationships throughout the course stimulated you to study and learn.

38. The teaching plans presented by the faculty contributed to the development of academic activities and to your studies.

39. The works referenced by the faculty in the lessons contributed to your studies and learning.

40. There were opportunities for students to overcome difficulties related to the training process.

41. Coordinators'/staff support were available for the academic guidance of students.

42. Your studies required of you: organization and frequent dedication to your studies.

43. Opportunities have been provided for students to participate in university extension programs, projects or activities.

44. Opportunities were provided for students to participate in scientific research projects and activities that stimulated academic research.

45. Your academic program provided opportunities for students to participate in internal and / or external events.

46. The institution provided opportunities for students to act as representatives in university committees.

47. The academic program utilized theoretical knowledge with practical activities.

48. The practical experiences were related to the contents of the course with the practice contributing to your professional training.

49. The academic program provided access to current and/or contemporary knowledge in its area of training.

50. The supervised internship provided diverse experiences for your training.

51. The activities carried out during your capstone project contributed to your professional training 
52. Opportunities have been offered for students to participate in exchanges and/or internships in Brazil

53. Opportunities have been offered for students to participate in exchanges and/or internships outside the country.

54. The students participated in periodic evaluations of the course (classes, performance of faculty members, infrastructure).

55. The assessments of learning during the course were congruent with the content taught by the faculty.

56. Faculty were available to assist students outside of class.

57. The faculty demonstrated mastery of the contents covered in class.

58. Faculty used information and communication technologies as a teaching strategy (multimedia projector, computer lab, and a virtual learning environment).

59. The institution has sufficient number of staff for administrative and academic support.

60. The academic program provided tutors to assist students.

61. The infrastructure conditions of the classrooms were adequate.

62. The equipment and materials available for the practical classes were adequate for the number of students.

63. The environment and equipment for the practical classes were adapted to the course.

64. The library provided resources that the students needed.

65. The institution had a virtual library or conferred access to works available in virtual collections.

66. The academic activities developed inside and outside the classroom created an opportunity for reflection, coexistence, and respect for diversity.

67. The institution promoted cultural, leisure, and social interaction activities.

68. The institution has a cafeteria and bathrooms and meets the needs of its users. 
Appendix D: Complete Coding Scheme variables

\begin{tabular}{|c|c|c|c|c|c|c|}
\hline Block & Items & $\begin{array}{l}\text { No. } \\
\text { variable } \\
\text { S }\end{array}$ & $\begin{array}{l}\text { Variable } \\
\text { name }\end{array}$ & Coding scheme raw data & Recoded to & Type \\
\hline 1 & Age & 1 & nu_idade & Continuous & Continuous & Continuous \\
\hline 1 & Sex & 1 & tp_sexo & $\begin{array}{l}\mathrm{M}=\text { Masculino } \\
\mathrm{F}=\text { Feminino }\end{array}$ & $\begin{array}{l}1=\text { female } \\
0=\text { male }\end{array}$ & Dichotomous \\
\hline 1 & Race & 1 & qe_i2 & $\begin{array}{ll}\text { A- } & \text { White } \\
\text { B- } & \text { Black } \\
\text { C- } & \text { Asian/yellow } \\
\text { D- } & \text { Brown } \\
\text { E- } & \text { Indigenous } \\
\text { F- } & \text { I prefer not to } \\
\text { disclose }\end{array}$ & $\begin{array}{l}\text { Referent } \\
\text { group=White }\end{array}$ & Dichotomous \\
\hline 1 & $\begin{array}{l}\text { Mother's educational } \\
\text { level } \\
\text { Up to what level of } \\
\text { schooling did your } \\
\text { mother complete? }\end{array}$ & 1 & qe_i5 & $\begin{array}{ll}\text { A- } & \text { None } \\
\text { B- } & \text { 1-4 grade } \\
\text { C- } & \text { 5-8th grade } \\
\text { D- } & \text { High School } \\
\text { E- } & \text { College } \\
\text { F- } & \text { Graduate School }\end{array}$ & $\begin{array}{l}0-5 \\
0-\text { No school } \\
\text { through } \\
5-\text { Graduate } \\
\text { school }\end{array}$ & Continuous \\
\hline 1 & $\begin{array}{l}\text { Father's educational } \\
\text { level } \\
\text { Up to what level of } \\
\text { schooling did your } \\
\text { father complete? }\end{array}$ & 1 & qe_i4 & $\begin{array}{ll}\text { A- } & \text { None } \\
\text { B- } & \text { 1-4 grade } \\
\text { C- } & \text { 5-8th grade } \\
\text { D- } & \text { High School } \\
\text { E- } & \text { College } \\
\text { F- } & \text { Graduate School }\end{array}$ & $\begin{array}{l}0-5 \\
0-\text { No school } \\
\text { through } \\
5-\text { graduate } \\
\text { school }\end{array}$ & Continuous \\
\hline
\end{tabular}




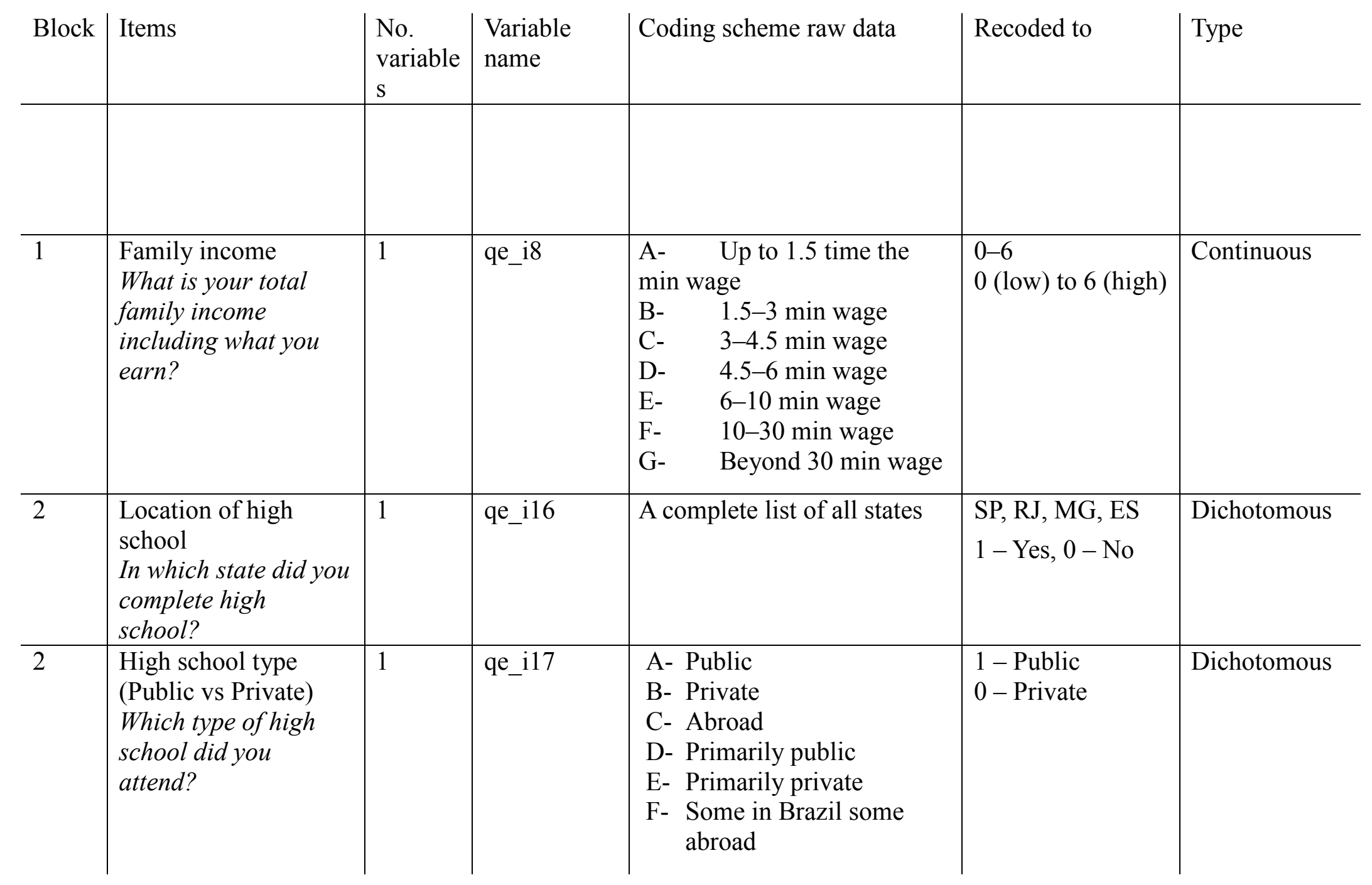




\begin{tabular}{|c|c|c|c|c|c|c|}
\hline Block & Items & $\begin{array}{l}\text { No. } \\
\text { variable } \\
\text { s }\end{array}$ & $\begin{array}{l}\text { Variable } \\
\text { name }\end{array}$ & Coding scheme raw data & Recoded to & Type \\
\hline 2 & $\begin{array}{l}\text { High school type of } \\
\text { courses } \\
\text { Which type of high } \\
\text { school did you } \\
\text { attend? }\end{array}$ & 1 & qe_i18 & $\begin{array}{l}\text { A-Traditional school } \\
\text { B- Technical } \\
\text { C-Profissionalizante } \\
\quad \text { magisterio } \\
\text { D-GED } \\
\text { E- Other }\end{array}$ & $\begin{array}{l}1-\quad \text { Traditional } \\
\text { high school } \\
0-\quad \text { Not } \\
\text { traditional }\end{array}$ & Dichotomous \\
\hline 3 & $\begin{array}{l}\text { Time of attendance } \\
\text { (Evening vs Day } \\
\text { time) } \\
\text { Do you attend night } \\
\text { classes? }\end{array}$ & 1 & in_noturno & $\begin{array}{l}0-\text { Nao } \\
1-\text { Yes }\end{array}$ & $\begin{array}{l}0-\text { No } \\
1-\text { Yes }\end{array}$ & Dichotomous \\
\hline 3 & $\begin{array}{l}\text { Living arrangement } \\
\text { during college } \\
\text { Where and with } \\
\text { whom do you live } \\
\text { currently? } \\
\text { Interpretation } \\
\text { On campus or with } \\
\text { other college students }\end{array}$ & 1 & qe_i6 & $\begin{array}{l}\text { A- In a house or apt, } \\
\text { alone. } \\
\text { B- In a house or apt, } \\
\text { with my parents } \\
\text { C- In a house or apt with } \\
\text { my spouse and children. } \\
\text { D- In an apt, or off- } \\
\text { campus with other college } \\
\text { students } \\
\text { E- On campus } \\
\text { F- Other }\end{array}$ & $\begin{array}{l}1-\text { On campus } \\
0-\text { Not on } \\
\text { campus }\end{array}$ & Dichotomous \\
\hline
\end{tabular}




\begin{tabular}{|c|c|c|c|c|c|c|}
\hline Block & Items & $\begin{array}{l}\text { No. } \\
\text { variable } \\
\text { S }\end{array}$ & $\begin{array}{l}\text { Variable } \\
\text { name }\end{array}$ & Coding scheme raw data & Recoded to & Type \\
\hline 3 & $\begin{array}{l}\text { Type of Affirmative- } \\
\text { action } \\
\text { Were you admitted } \\
\text { through an } \\
\text { affirmative-action } \\
\text { program? }\end{array}$ & 1 & qe_i15 & $\begin{array}{l}\text { A- } \quad \text { No } \\
\text { B- } \quad \text { Yes, racial-ethnic } \\
\text { category } \\
\text { C- } \quad \text { Yes, SES } \\
\text { D- } \quad \text { Yes, public high } \\
\text { school attendance } \\
\text { E- } \quad \text { Yes, a combination } \\
\text { F- } \quad \text { Yes, other }\end{array}$ & $\begin{array}{l}\text { C - SES - } 1 \& \text { F- } \\
\text { other (disability); } \\
0 \text { - others }\end{array}$ & Dichotomous \\
\hline 3 & $\begin{array}{l}\text { Major What is your } \\
\text { major? }\end{array}$ & 1 & co_grupo & $\begin{array}{l}5=\text { MEDICINA } \\
\text { VETERINÁRIA } \\
6=\text { ODONTOLOGIA } \\
12=\text { MEDICINA } \\
17=\text { AGRONOMIA } \\
19=\text { FARMÁCIA } \\
23=\text { ENFERMAGEM } \\
27=\text { FONOAUDIOLOGIA } \\
28=\text { NUTRIÇÃO } \\
36=\text { FISIOTERAPIA } \\
38=\text { SERVIÇO SOCIAL }\end{array}$ & $\begin{array}{l}\text { Major were coded } \\
\text { as STEM (coded } \\
\text { value }-1 \text { ) and } \\
\text { Non-STEM } \\
\text { (coded value }-0 \text { ). } \\
\text { STEM= } \\
\text { (MEDICINA } \\
\text { VETERINÁRIA } \\
6= \\
\text { ODONTOLOGIA } \\
12=\text { MEDICINA } \\
17= \\
\text { AGRONOMIA } \\
19=\text { FARMÁCIA }\end{array}$ & \\
\hline
\end{tabular}




\begin{tabular}{|c|c|c|c|c|c|c|}
\hline Block & Items & $\begin{array}{l}\text { No. } \\
\text { variable } \\
\text { s }\end{array}$ & $\begin{array}{l}\text { Variable } \\
\text { name }\end{array}$ & Coding scheme raw data & Recoded to & Type \\
\hline & & & & $\begin{array}{l}51=\text { ZOOTECNIA } \\
55=\text { BIOMEDICINA } \\
693501=\text { EDUCAÇÃO } \\
\text { FÍSICA } \\
(\text { BACHARELADO) }\end{array}$ & $\begin{array}{l}23= \\
\text { ENFERMAGEM } \\
\text { NUTRIÇÃO } \\
\text { ZOOTECNIA } \\
55= \\
\text { BIOMEDICINA } \\
\text { NO NON-STEM } \\
\text { (EDUCAÇÃO } \\
\text { FÍSICA } \\
\text { (BACHARELAD } \\
\text { O) } \\
\text { FISIOTERAPIA } \\
38=\text { SERVIÇO } \\
\text { SOCIAL; } \\
\text { FONOAUDIOLO } \\
\text { GIA }\end{array}$ & \\
\hline
\end{tabular}




\begin{tabular}{|c|c|c|c|c|c|c|}
\hline Block & Items & $\begin{array}{l}\text { No. } \\
\text { variable } \\
\text { s }\end{array}$ & $\begin{array}{l}\text { Variable } \\
\text { name }\end{array}$ & Coding scheme raw data & Recoded to & Type \\
\hline 3 & $\begin{array}{l}\text { Reason for selecting a } \\
\text { particular major } \\
\text { Why did you choose } \\
\text { this major? }\end{array}$ & 1 & qe_i25 & $\begin{array}{l}\text { A-To enter the labour } \\
\text { market } \\
\text { B-Encouragement from } \\
\text { family } \\
\text { C-Professional } \\
\text { D-Social prestige } \\
\text { E-Vocational } \\
\text { F-Distance learning } \\
\text { available } \\
\text { G-Easier to get into } \\
\text { H-Other }\end{array}$ & $\begin{array}{l}\text { G- A \& D } \\
\text { (labour market or } \\
\text { social prestige) } \\
0 \text { - All other } \\
\text { answers }\end{array}$ & Dichotomous \\
\hline 3 & $\begin{array}{l}\text { Reason for selecting } \\
\text { this university? } \\
\text { Interpret } \\
\text { Did you select this } \\
\text { university because of } \\
\text { its proximity to } \\
\text { home? }\end{array}$ & 1 & qe_i26 & $\begin{array}{l}\text { A- Free } \\
\text { B- Tuition costs } \\
\text { C- Proximity to home } \\
\text { D- Proximity to work } \\
\text { E- Easy access } \\
\text { F- Reputation/quality } \\
\text { G- Only one I was accepted } \\
\quad \text { into } \\
\text { H- Scholarships } \\
\text { I- Other reason }\end{array}$ & $\begin{array}{l}1-\text { Yes }(\mathrm{C}) \\
0-\text { No (all else) }\end{array}$ & 0 \\
\hline
\end{tabular}




\begin{tabular}{|c|c|c|c|c|c|c|}
\hline Block & Items & $\begin{array}{l}\text { No. } \\
\text { variable } \\
\text { S }\end{array}$ & $\begin{array}{l}\text { Variable } \\
\text { name }\end{array}$ & Coding scheme raw data & Recoded to & Type \\
\hline 3 & Institutional Ranking & 1 & $\begin{array}{l}\text { Created } \\
\text { variable } \\
\text { from MEC } \\
\text { IGC }\end{array}$ & IGC ranking of 5 - selective & $\begin{array}{l}\text { 1, Highly } \\
\text { selective }\end{array}$ & 1 \\
\hline 4 & $\begin{array}{l}\text { Financial situation } \\
\text { Which best describes } \\
\text { your financial } \\
\text { situation? } \\
\text { Interpret } \\
\text { Did you provide } \\
\text { financial assistance } \\
\text { to your family? }\end{array}$ & 1 & qe_i9 & $\begin{array}{l}\text { A- No income, my } \\
\text { expenses are financed by } \\
\text { govt programs } \\
\text { B- No income, my } \\
\text { family and friends finance } \\
\text { my studies } \\
\text { C- I earn some money, } \\
\text { buy my family contributes } \\
\text { to my educational expenses } \\
\text { D- I have income and } \\
\text { don't need help to pay my } \\
\text { expenses } \\
\text { E- I have an income and } \\
\text { contribute my family } \\
\text { income (to support) } \\
\text { F- I am the sole } \\
\text { financial contributor } \\
\text { responsible my family }\end{array}$ & $\begin{array}{l}1-\quad \text { Yes }(\mathrm{E}-\mathrm{F}) \\
0-\quad \text { No }(\mathrm{A}-\mathrm{D})\end{array}$ & Dichotomous \\
\hline
\end{tabular}




\begin{tabular}{|c|c|c|c|c|c|c|}
\hline Block & Items & $\begin{array}{l}\text { No. } \\
\text { variable } \\
\text { s }\end{array}$ & $\begin{array}{l}\text { Variable } \\
\text { name }\end{array}$ & Coding scheme raw data & Recoded to & Type \\
\hline 4 & $\begin{array}{l}\text { Working status } \\
\text { How often do you } \\
\text { work (excluding } \\
\text { scholarship or } \\
\text { internships)? }\end{array}$ & 1 & qe_i10 & $\begin{array}{l}\text { A- I don't work } \\
\text { B- Sometimes } \\
\text { C- Up to } 20 \text { hours } \\
\text { D- Between } 21-39 \\
\text { E- I work } 40 \text { or more }\end{array}$ & $\begin{array}{l}\text { A-B - } 0 \text { (Don't } \\
\text { work) } \\
\text { C-E - } 1 \text { (Work) }\end{array}$ & Dichotomous \\
\hline 4 & $\begin{array}{l}\text { Financing/Need based } \\
\text { scholarship } \\
\text { What type of } \\
\text { scholarship or } \\
\text { financing did you use } \\
\text { to fund your studies? } \\
\text { Interpret } \\
\text { Did you earn a } \\
\text { scholarship? }\end{array}$ & 1 & qe_i11 & $\begin{array}{l}\text { A- None my university } \\
\text { is free } \\
\text { B- None, even though } \\
\text { my studies have tuition fee } \\
\text { C- ProUni Integral } \\
\text { D- ProUni Parcial } \\
\text { E- FIES, apenas } \\
\text { F- ProUni Parcial e } \\
\text { FIES } \\
\text { G- Bolsa Oferecida por } \\
\text { gov estadual, distrital ou } \\
\text { munincipal } \\
\text { H- University } \\
\text { scholarship } \\
\text { I- Scholarship from } \\
\text { other agencies } \\
\text { J- University financing } \\
\text { options }\end{array}$ & $\begin{array}{l}\text { Received } \\
\text { scholarships - } 1 \\
(\mathrm{G}, \mathrm{H}, \mathrm{I}) \\
\text { None }-0 \text { (All } \\
\text { others) (Issue here } \\
\text { is that public } \\
\text { universities are } \\
\text { already free) }\end{array}$ & Dichotomous \\
\hline
\end{tabular}




\begin{tabular}{|c|c|c|c|c|c|c|}
\hline Block & Items & $\begin{array}{l}\text { No. } \\
\text { variable } \\
\text { S }\end{array}$ & $\begin{array}{l}\text { Variable } \\
\text { name }\end{array}$ & Coding scheme raw data & Recoded to & Type \\
\hline & & & & K- $\quad$ Bank financing $/ 1 \mathrm{c}$ & & \\
\hline 4 & $\begin{array}{l}\text { Retention services } \\
\text { During your studies } \\
\text { did you receive any } \\
\text { type of retention } \\
\text { (Housing, food, } \\
\text { retention, or other)? }\end{array}$ & 1 & qe_i12 & $\begin{array}{ll}\text { A- } & \text { None } \\
\text { B- } & \text { Housing } \\
\text { C- } & \text { Food } \\
\text { D- } & \text { Food and housing } \\
\text { E- } & \text { Retention } \\
\text { F- } & \text { Other type }\end{array}$ & $\begin{array}{l}1 \text { Yes (B-F) } \\
0-\mathrm{NO}(\mathrm{A})\end{array}$ & \\
\hline
\end{tabular}




\begin{tabular}{|c|c|c|c|c|c|c|}
\hline Block & Items & $\begin{array}{l}\text { No. } \\
\text { variable } \\
\text { s }\end{array}$ & $\begin{array}{l}\text { Variable } \\
\text { name }\end{array}$ & Coding scheme raw data & Recoded to & Type \\
\hline 4 & $\begin{array}{l}\text { Academic scholarship } \\
\text { During your } \\
\text { schooling, did you } \\
\text { receive any academic } \\
\text { scholarships? }\end{array}$ & 1 & qe_i13 & $\begin{array}{l}\text { A- None } \\
\text { B- Research project } \\
\text { scholarship } \\
\text { C- Community based } \\
\text { engagement scholarship } \\
\text { D- Teaching } \\
\text { assistantship } \\
\text { E- PET scholarship (UG } \\
\text { led research) } \\
\text { F- Other type of } \\
\text { academic scholarship }\end{array}$ & $\begin{array}{l}1-\text { Yes }(B-F) \\
0-\text { NO (A) }\end{array}$ & \\
\hline 5 & $\begin{array}{l}\text { Social Support } \\
\text { Who encouraged you } \\
\text { to go to college? } \\
\text { Interpret the question } \\
\text { as } \\
\text { Did you receive } \\
\text { encouragement? }\end{array}$ & 1 & qe_i19 & $\begin{array}{l}\text { A-No one } \\
\text { B-Parents } \\
\text { C-Other family members } \\
\text { D-Faculty members } \\
\text { E-Religious leader } \\
\text { F-Friends/classmates } \\
\text { G-Others }\end{array}$ & $\begin{array}{l}\text { 1- } \quad \text { Yes }(B-G) \\
0-\quad \text { NO (A) }\end{array}$ & \\
\hline
\end{tabular}




\begin{tabular}{|c|c|c|c|c|c|c|}
\hline Block & Items & $\begin{array}{l}\text { No. } \\
\text { variable } \\
\text { s }\end{array}$ & $\begin{array}{l}\text { Variable } \\
\text { name }\end{array}$ & Coding scheme raw data & Recoded to & Type \\
\hline 5 & $\begin{array}{l}\text { Social Support } \\
\text { Were any of the } \\
\text { groups below decisive } \\
\text { in helping you face } \\
\text { difficulty situations } \\
\text { during your college } \\
\text { course and } \\
\text { completing it? }\end{array}$ & 1 & qe_i20 & 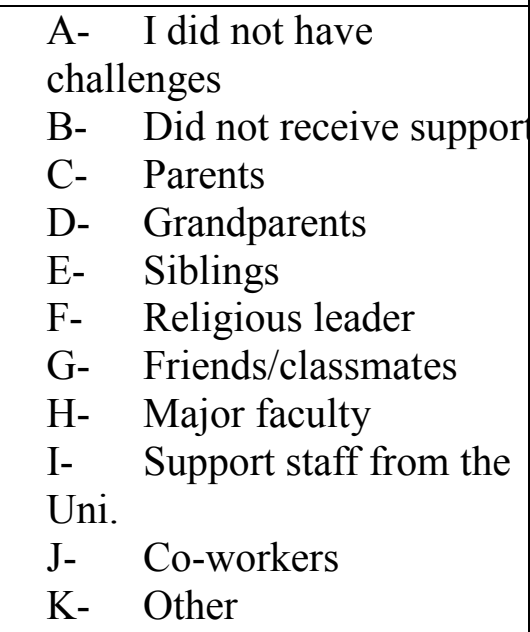 & $\begin{array}{l}\text { Received support } \\
\text { (1) } \\
\text { Did not receive } \\
\text { support }(0)\end{array}$ & Dichotomous \\
\hline 5 & $\begin{array}{l}\text { Institutional/Faculty } \\
\text { Support (1-6 scale, } 1 \\
\text { - Strongly disagree, } 6 \\
\text { - Strongly agree) } \\
\text { Faculty-student } \\
\text { relationships } \\
\text { throughout the course } \\
\text { stimulated you to } \\
\text { study and learn. }\end{array}$ & 7 & qe_i37 & & See appendix A & \\
\hline
\end{tabular}




\begin{tabular}{|c|c|c|c|c|c|c|}
\hline Block & Items & $\begin{array}{l}\text { No. } \\
\text { variable } \\
\text { S }\end{array}$ & $\begin{array}{l}\text { Variable } \\
\text { name }\end{array}$ & Coding scheme raw data & Recoded to & Type \\
\hline & $\begin{array}{l}\text { Faculty members } \\
\text { were available to } \\
\text { assist students outside } \\
\text { of class time. }\end{array}$ & & qe_i56 & & & \\
\hline & $\begin{array}{l}\text { There were } \\
\text { opportunities for } \\
\text { students to overcome } \\
\text { difficulties related to } \\
\text { the training process }\end{array}$ & & qe_i40 & & & \\
\hline & $\begin{array}{l}\text { The institution had } \\
\text { sufficient staff for } \\
\text { administrative and } \\
\text { academic support. }\end{array}$ & & qe_i59 & & & \\
\hline & $\begin{array}{l}\text { The institution } \\
\text { provided tutoring } \\
\text { services to assist } \\
\text { students }\end{array}$ & & qe_i60 & & & \\
\hline & $\begin{array}{l}\text { The academic } \\
\text { activities developed } \\
\text { inside and outside the } \\
\text { classroom made } \\
\text { possible reflection, }\end{array}$ & & qe_i66 & & & \\
\hline
\end{tabular}




\begin{tabular}{|c|c|c|c|c|c|c|}
\hline Block & Items & $\begin{array}{l}\text { No. } \\
\text { variable } \\
\text { s }\end{array}$ & $\begin{array}{l}\text { Variable } \\
\text { name }\end{array}$ & Coding scheme raw data & Recoded to & Type \\
\hline & $\begin{array}{l}\text { coexistence, and } \\
\text { respect for diversity. }\end{array}$ & & & & & \\
\hline & $\begin{array}{l}\text { The institution } \\
\text { promoted activities of } \\
\text { cultural, leisure, and } \\
\text { social interaction. }\end{array}$ & & qe_i67 & & & \\
\hline 6 & $\begin{array}{l}\text { Number of hours } \\
\text { spent studying } \\
\text { How many hours per } \\
\text { week did you spend } \\
\text { studying (excluding } \\
\text { class time)? }\end{array}$ & 1 & qe_i23 & $\begin{array}{l}\text { A- None, I only go to } \\
\text { class. } \\
\text { B- } 1 \text { to } 3 \\
\text { C- } 4 \text { to } 7 \\
\text { D- } 8 \text { to } 12 \\
\text { E- } \quad \text { More than } 12\end{array}$ & $\begin{array}{l}\text { (0) None to } \\
\text { (4) to }+8 \text { hours. } \\
\text { Variables are } \\
\text { coded from low } \\
\text { to high. } \\
\text { 0-A,1-B,2-C,3- } \\
\text { D,4-E }\end{array}$ & Continuous \\
\hline 6 & $\begin{array}{l}\text { Reading for pleasure } \\
\text { Excluding books } \\
\text { required for class, } \\
\text { how many books did } \\
\text { you read this year? }\end{array}$ & 1 & qe_i22 & $\begin{array}{ll}\text { A- } & \text { None } \\
\text { B- } & 1 \text { or } 2 \\
\text { C- } & 3 \text { to } 5 \\
\text { D- } & 6 \text { to } 8 \\
\text { E- } & \text { More than } 8\end{array}$ & $\begin{array}{l}\text { (0) None to } \\
(4) \text { to }+8 \text { books. } \\
\text { Variables are } \\
\text { coded from low } \\
\text { to high. A }-0, \mathrm{~B} \\
-1, \mathrm{C}-2, \mathrm{D}- \\
3, \mathrm{E}-4\end{array}$ & Continuous \\
\hline
\end{tabular}




\begin{tabular}{|c|c|c|c|c|c|c|}
\hline Block & Items & $\begin{array}{l}\text { No. } \\
\text { variable } \\
\text { S }\end{array}$ & $\begin{array}{l}\text { Variable } \\
\text { name }\end{array}$ & Coding scheme raw data & Recoded to & Type \\
\hline 6 & $\begin{array}{l}\text { Foreign language } \\
\text { Did you have an } \\
\text { opportunity to learn a } \\
\text { foreign language at } \\
\text { your university? }\end{array}$ & 1 & qe_i24 & $\begin{array}{l}\text { A- Yes, in-person class } \\
\text { B- Yes, hybrid class } \\
\text { C- Yes, some in person } \\
\text { and some online } \\
\text { D- Yes, online } \\
\text { E- No }\end{array}$ & $\begin{array}{l}\text { Recode } \\
1(\text { A-D) - Yes } \\
0(E)-\text { No }\end{array}$ & \\
\hline
\end{tabular}




\section{References}

Aguiar Bravo, M. H. (2017). Enem e o percurso histórico do conceito de avaliação: implicações das e para as políticas educacionais. Universidade de Sao Paulo.

Allen, W., Teranishi, R., Dinwiddie, G., \& Gonzalez, G. (2000). Introduction and overview knocking at freedom's door: race, equity and affirmative action in U.S. higher education. The Journal of Negro Education, 69(1), 3-11. Retrieved from http://www.jstor.org/stable/2696260

Antunes, L. (2018). Bolsonaro promete reduzir cotas para universidades e concursos. [Bolsonaro promises to reduce quotas for universities and goverment jobs]. $U O L$ Noticias.

Astin, A. W. (1993). What matters in college? Four critical years revisited (1st ed.). San Francisco: Jossey-Bass.

Astin, A. W. (1999). Student Involvement: A Development Theory for Higher Education. Journal of College Student Development, 40(5), 518-529. https://doi.org/10.1016/0263-

Astin, A. W., \& Denson, N. (2009). Multi-campus studies of college impact: Which statistical method is appropriate? Research in Higher Education, 50(4), 354-367. https://doi.org/10.1007/s11162-009-9121-3

Bailey, S. R. (2008). Unmixing for race making in Brazil. American Journal of Sociology, 114(3). https://doi.org/10.1086/592859

Bailey, S. R., \& Telles, E. (2006). Multiracial versus collective black categories Examining census classification debates in Brazil. Ethnicities, 6(1), 74-101. https://doi.org/10.1177/1468796806061080

Barker, C. (2004). The SAGE dictionary of cultural studies. London: SAGE Publications Ltd. 
Bennett, D. A. (2001). How can I deal with missing data in my study? Aust N Z J Public Health, 25(5), 464-469. https://doi.org/10.1111/j.1467-842X.2001.tb00294.x

Bergkvist, L., \& Rossiter, J. R. (2007). The Predictive Validity of Multiple-Item Versus Single-Item Measures of the Same Constructs. Journal of Marketing Research, 44(2), 175-184. https://doi.org/10.1509/jmkr.44.2.175

Bezzera, T. O. C. (2010). Politica de cotas em universidades e inclusão social: desempenho de alunos cotistas e sua aceitação no grupo acadêmico [University quotas policy and social inclusion: performance of quota students and their acceptance in the academic peer group]. Universidad de la Empresa/Uruguai.

Boxill, B. (2003). Affirmative action in higher education. In R. Curren (Ed.), $A$ companion to the philosophy of education. (pp. 593-604). Malden, MA: Blackwell Publisher.

Brazil. Dispõe sobre o ingresso nas universidades federais e nas instituições federais de ensino técnico de nível médio e dá outras providências [Provides for admission to federal universities and federal institutions of technical secondary education and provides, Pub. L. No. 12.711 (2012). Brazil. Retrieved from http://www.planalto.gov.br/ccivil_03/_ato2011-2014/2012/lei/112711.htm

Cardoso, C. B. (2008). Efeitos da política de cotas na Universidade de Brasília : uma análise do rendimento e da evasão. University of Brasilia. Retrieved from http://repositorio.unb.br/handle/10482/1891

Census - População residente, por cor ou raça, segundo a situação do domicílio, o sexo e a idade [ Census - Resident population, by color or race, according to household status, sex and age]. (2010). Retrieved from https://sidra.ibge.gov.br/Tabela/3175

Cerqueira Lima, A. M., \& Pereire de Anunciacao, M. P. (2008). Perfil socioeconômico dos candidatos inscritos e classificados no concurso vestibular da UFBA 
[Socioeconomic profile of the candidates enrolled and classified in the entrance examination of UFBA]. Salvador, Bahia.

Childs, P., \& Stromquist, N. (2015). Academic and diversity consequences of affirmative action in Brazil. Compare: A Journal of Comparative and International Education, 45(5), 792-813.

Chor Maio, M., \& Ventura Santos, R. (2005). Política de cotas raciais, os " olhos da sociedade " e os usos da antropologia: o caso do vestibular da Universidade de Brasília [Politics of racial quotas, the "eyes of society" and the uses of anthropology: the case of the vestibular of the university o. Horizontes Antropologicos, 11(23), $181-214$.

Cohen, J. (1988). Statistical power analysis for the behavioral sciences (2nd ed.). Hillsdale, NJ: Lawrence Earlbaum Associates.

Courville, T., \& Thompson, B. (2001). Use of Structure Coefficients in Published Multiple Regression Articles : B Is Not Enough. Educational and Psychological Measurement, 61 No 2(April), 229-248. https://doi.org/10.1177/0013164401612006

Creswell, J. W. (2005). Planning, Conducting, and Evaluating Quantitative and Qualitative Research. (P. A. Smith, C. Robb, M. Buchholtz, J. Sabella, \& K. Mason, Eds.) (4th ed.). Pearson.

Crisp, G., \& Nora, A. (2009). Hispanic student success: Factors influencing the persistence and transfer decisions of latino community college students enrolled in developmental education. Research in Higher Education, 51(2), 175-194. https://doi.org/10.1007/s11162-009-9151-x

Crisp, G., Taggart, A., \& Nora, A. (2015). Undergraduate Latina / o Students : A Systematic Review of Research Identifying Factors Contributing to Academic Success Outcomes. Research on Hispanic Students, 85(2), 249-274. https://doi.org/10.3102/0034654314551064 
Cutrona, C. E., Cole, V., Colangelo, N., Assouline, S. G., \& Russell, D. W. (1994). Perceived parental social support and academic achievement: An attachment theory perspective. Journal of Personality and Social Psychology, 66(2), 369-378. https://doi.org/10.1037//0022-3514.66.2.369

Darby, D. (2010). Educational inequality and affirmative action in Brazil. Peace Review: A Journal of Social Justice, 22(4), 408-415. https://doi.org/10.1080/10402659.2010.524565

de la Iglesia, G., Stover, J. B., \& Liporace, M. F. (2014). Perceived social support and academic achievement in Argentinean college students. Europe's Journal of Psychology, 10(4), 637-649. https://doi.org/10.5964/ejop.v10i4.777

de Oliveira, C. (2018, June 30). Is Neymar Black? Brazil and the Painful Relativity of Race. The New York Times (Opinon). Retrieved from https://www.nytimes.com/2018/06/30/opinion/is-neymar-black-brazil-and-thepainful-relativity-of-race.html

De Souza, C., \& France-Presse, A. (2018). Brazil edges toward Bolsonaro as a 'Last Resort' leader. The New York Times.

Diamantopoulos, A., Sarstedt, M., Fuchs, C., Wilczynski, P., \& Kaiser, S. (2012). Guidelines for choosing between multi-item and single-item scales for construct measurement: A predictive validity perspective. Journal of the Academy of Marketing Science, 40(3), 434-449. https://doi.org/10.1007/s11747-011-0300-3

Dias Lopes, A. (2017). Affirmative action in Brazil: how students' field of study choice reproduces social inequalities. Studies in Higher Education, 42(12), 2343-2359. https://doi.org/10.1080/03075079.2016.1144180

Dong, Y., \& Peng, C.-Y. J. (2013). Principled missing data method the researchers. Springer Plus, 2(222), 1-17.

Dos Santos, D. A. R., Amoedo da Costa, M., \& Da Silva Faceira, L. (2015). O estado da arte no campo dos estudos sobre o PROUNI [The state of the art in the field of 
studies on PROUNI]. Revista de Serviço Social UNIGRANRIO, 1(1), 1-16.

Retrieved from

http://publicacoes.unigranrio.edu.br/index.php/mrss/article/view/3025/1404

Dos Santos, S. A. (2014). Ações afirmativas nos governos FHC e Lula : um balanço [Affirmative action in the presidencies of FHC and Lula : an evaluation]. Revista TOMO, (24), 37-84. https://doi.org/http://dx.doi.org/10.21669/tomo.v0i0

Eakin, M. C. (1985). Race and Identity : Sílvio Romero, Science, and Social Thought in Late 19th Century Brazil Stable URL: https://www.jstor.org/stable/3513452 Race and Identity : Silvio Romero, Science, and Social Thought in Late 19th Century Brazil. Luso-Brazilian Review, 22(2), 151-174.

Economia do Sudeste [Southeast's economy]. (n.d.). Retrieved from https://www.suapesquisa.com/economia/economia_sudeste.htm

Evans, N. J., Forney, D. S., Guido, F. M., Patton, L. D., \& Renn, K. A. (2010). Student development in college (2nd ed.). San Francisco: Jossey-Bass.

Fávero De Albuquerque, M. de L. (2006). A universidade no Brasil : das origens à reforma universitária de 1968 [University in Brazil : from its origins to university reform - 1968]. Educar Em Revista, 28, 17-36.

Field, A. (2009). Discovering statistics using SPSS (3rd ed.). London: SAGE Publications Ltd.

Fischer, M. J. (2010). A longitudinal examination of the role of stereotype threat and racial climate on college outcomes for minorities at elite institutions. Social Psychology of Education, 13(1), 19-40. https://doi.org/10.1007/s11218-009-9105-3

Francis, A. M., \& Tannuri-Pianto, M. (2012a). The redistributive equity of affirmative action: Exploring the role of race, socioeconomic status, and gender in college admissions. Economics of Education Review, 31(1), 45-55. https://doi.org/10.1016/j.econedurev.2011.08.005 
Francis, A. M., \& Tannuri-Pianto, M. (2012b). Using Brazil's racial continuum to examine the short-term effects of affirmative action in higher education. Journal of Human Resources, 47(3), 754-784. https://doi.org/10.1353/jhr.2012.0024

Frisancho, V., \& Krishna, K. (2016). Affirmative action in higher education in India: targeting, catch up, and mismatch. Higher Education, 71(5), 611-649. https://doi.org/10.1007/s10734-015-9927-1

Gipson, J. (2016). Predicting academic success for students of color within STEM majors. Journal for Multicultural Education, 10(2), 124-134. https://doi.org/10.1108/JME-12-2015-0044

Gloria, A., Castellanos, J., \& Rosales, R. (2005). An Examination of Academic Nonpersistence Decisions of Latino Undergraduates. Hispanic Journal of Behavioral Sciences, 27(2), 202-223. https://doi.org/10.1177/0739986305275098

Guimarães, A. S. A. (2003). Acesso de negros às universidades públicas [Access of Blacks to public universities]. Cadernos de Pesquisa, 118, 247-268.

Harper, S. R.; Quaye, S. J. (2009). Student engagement in higher education: Theoretical perspectives and practical approaches for diverse populations. New York, NY: Routledge.

Heriot, G. (2011). Just say no to affirmative action. Academic Questions, 24(4), 449-466. https://doi.org/10.1007/s12129-011-9257-4

Hernandez, J. C. (2000). Understanding the Retention of Latino College Students. Journal of College Student Development, 41(6), 575-588. https://doi.org/10.2190/C0C4-EFT9-EG7W-PWP4

Htun, M. (2004). From " racial democracy " to affirmative action: changing state policy on race in Brazil. Latin American Research Review, 39(1), 60-89. Retrieved from http://www.jstor.org/stable/1555383 .\%0AAccessed: 
Hunger, D., Rossi, F., \& Souza Neto, S. de. (2011). A teoria de Norbert Elias: uma análise do ser professor. Educação e Pesquisa, 37(4), 697-710. https://doi.org/10.1590/S1517-97022011000400002

Hurtado, S., Clayton-Pedersen, A. R., Allen, W. R., \& Milem, J. F. (1998). Enhancing campus climates for racial/ethnic diversity: educational policy and practice. The Review of Higher Education, 21(3), 279-302.

Instituto Brasileiro de Geografia e Estatística. (2015). Sintese de Indicadores Sociais: Uma analise das condicoes de vida da populacao Brasileira [Synthesis of social indicators: an analysis of the living] (Vol. 39). Rio de Janeiro. https://doi.org/ISSN $0101-4234$

Instituto Brasileiro de Geografia e Estatística. (2017). Sintese de Indicadores Sociais: Uma analise das condicoes de vida da populacao Brasileira [Synthesis of social indicators: An analysis of the living conditions of the Brazilian population] (37th ed.). Rio de Janeiro.

Instituto Nacional de Estudos e Pesquisas Educacionais Anísio Teixeira (INEP). (2015). Enade- Exame nacional de desempenho de estudantes [National student perfomance exam]. Retrieved from http://inep.gov.br/web/guest/enade

Jackson, L. (2008). Reconsidering affirmative action in education as a good for the disadvantaged. Journal of Critical Education Policy Studies, 6(1), 379-397. Retrieved from http://www.jceps.com/archives/577

Jayakumar, U. M. (2002). Can higher education meet the needs of an increasingly diverse and global society? Campus diversity and cross-cultural workforce competencies. Harvard Education Review, 78(4), 615-652.

Leite, D. (2010). Estudantes e avaliação. Avaliação: Revista Da Avaliação Da Educação Superior (Campinas), 15(3), 9-27. https://doi.org/10.1590/S141440772010000300002 
Loveman, M., Muniz, J. O., \& Bailey, S. R. (2012). Brazil in black and white? Race categories, the census, and the study of inequality. Ethnic and Racial Studies. https://doi.org/10.1080/01419870.2011.607503

Maggie, Y., \& Fry, P. (2004). A reserva de vagas para negros nas universidade brasileiras [Quotas for blacks in Brazilian universities]. Estudos Avançados, 18(50), 67-80. https://doi.org/10.1590/S0103-40142004000100008

Malecki, C. K., \& Demaray, M. (2006). Social support as a buffer in the relationship between socioeconomic status and academic performance. School Psychology Quarterly, 21(4), 375-395.

Mendes Junior, A. A. F., De Mello e Souza, A., \& Waltenberg, F. D. (2016). Affirmative Action and Access to Higher Education in Brazil : The Signi fi cance of Race and Other Social Factors. Journal of Latin American Studies, 48, 301-334. https://doi.org/10.1017/S0022216X16000018 First

Menin, M., Shimizu, A., Da Silva, J., Cioldi, F. L., \& Buschini, F. (2008). Representações de estudantes universitários sobre alunos cotistas: confronto de valores [University students' representation of quota students: a confrontation of values]. Educação e Pesquisa, 34(2), 255-272.

Ministério da Educação - Brasil [Brazil Ministry of Education]. (2007). REUNI Reestruturacao e expansao das universidades federais [Restructure and expansion of the federal universities]. Retrieved from http://reuni.mec.gov.br/

Ministério da Educação - Brasil [Brazil Ministry of Education]. (2012). Ensino Superior Entenda como funciona o novo sistema de cotas [ Understand the new quota system for higher education].

Ministério da Educação - Brasil [Brazil Ministry of Education]. (2018). O que e Prouni [What is Prouni]. Retrieved from http://siteprouni.mec.gov.br/tire_suas_duvidas.php 
Nogueira, C. M. M. (2013). A abordagem de Bernard Lahire e as contribuições para a sociologia de educação [Bernard Lahire's approach and contributions to the sociology of education]. In $36^{a}$ Reunião Nacional da ANPEd (pp. 1-24). Goiania.

Norman, K. (2011). Identity and public policy: redefinding the concept of racial democracy in Brazil. Harvard Journal of African American Public Policy, 17, 1-19.

Para UNB, um era branco e outro, negro [To UnB one was White and the other Black]. (2012, October 28). O Estado de S.Paulo. Retrieved from https://www.estadao.com.br/noticias/geral,para-unb-um-era-branco-e-outro-negroimp-, 951965

Pedrosa, R. H. L. N. H., Dachs, J. N. W., Maia, R. P., Andrade, C. Y., \& Carvalho, B. S. (2007). Academic performance, students' background and affirmative action at a Brazilian university. Higher Education Management and Policy, 19(3), 67-86.

Peixoto, A. de L. A., Ribeiro, E. M. B. de A., Bastos, A. V. B., \& Ramalho, M. C. K. (2016). Cotas e desempenho acadêmico na UFBA: um estudo a partir dos coeficientes de rendimento. Avaliação: Revista Da Avaliação Da Educação Superior (Campinas), 21(2), 569-592. https://doi.org/10.1590/S141440772016000200013

Peng, C.-Y. J., Harwell, M., Liou, S.-M., Ehman, L. H., \& others. (2006). Advances in missing data methods and implications for educational research. Real Data Analysis, 10(1), 31-78. https://doi.org/10.1186/1476-072X-10-67

Pereira dos Santos, A. (2011). Políticas de ação afirmativa, novo ingrediente na luta pela democratização do ensino superior: a experiência da Universidade Federal de Ouro Preto [Affirmative action policies, a new ingredient in the struggle for the democratization of higher education] . Universidade do Estado do Rio de Janeiro.

Petrocelli, J. V. (2003). Hierarchical Multiple Regression in Counseling Research: Common Problems and Possible Remedies John. Measurement and Evaluation in Counseling and Development, 36(April), 9-22. 
Portes, E. A. (2001). Trajetórias escolares e vida acadêmica do estudante pobre da UFMG: um estudo a partir de cinco casos [ School trajectories and academic life of UFMG's poor students : a study of five cases]. University Federal of Minas Gerais.

Predrosa, R., Amaral, E., \& Knobel, M. (2013). Assessing higher education learning outcomes in Brazil by Évaluation des résultats de renseignement supérieur au Brésil. Higher Education Management and Policy, 24(2), 55-71.

Quevedo-silva, F., \& Sauer, L. (Eds.). (2009). Revista Pensamento \& Realidade. In Revista Pensamento \& Realidade (pp. 173-199).

Ribeiro, A. (2016). Affirmative action outcomes : evidence from a Law School in Brazil. Sao Paulo. Retrieved from http://www.cedlaser.org/sites/default/files/aux_files/ribeiro_0.pdf

Salário Mínimo [Minimum wage]. (2018). Retrieved from https://www.suapesquisa.com/o_que_e/salario_minimo.htm

Sander, R. H., Stanford, S., Review, L., Nov, N., Review, S. L., \& Sander, R. H. (2017). Stanford law review a systemic analysis of affirmative action in American law schools. Stanford Law Review, 57(2), 367-483. Retrieved from http://www.jstor.org/stable/40040209

Santos, S. A. dos. (2007). Movimentos negros, educação e ações afirmativas [ Black movements, education, and affirmative action]. Sociedade e Estado. University of Brasilia. https://doi.org/10.1590/S0102-69922008000100010

Saviani, D. (2010). A organização da educação nacional na Nacional de Educação [Organization of National Education: System and National Council Of Education, Plan and National Forum Of Education]. Educação e Sociedade, 32, 769-787.

Schafer, W. D. (1991). Reporting Hierarchical Regression Results. Measurement and Evaluation in Counseling and Development, 24(1989), 98-100. 
Schwartzman, L. F., \& da Silva, G. M. D. (2012). Unexpected narratives from multicultural policies: translations of affirmative action in Brazil. Latin American and Caribbean Ethnic Studies, 7(1), 31-48. https://doi.org/10.1080/17442222.2012.658295

Schwartzman, L. F., \& Paiva, A. R. (2016). Not just racial quotas: affirmative action in Brazilian higher education 10 years later. British Journal of Sociology of Education, 37(4), 548-566. https://doi.org/10.1080/01425692.2014.973015

Schwartzman, S. (2005). O enigma do ENADE [ENADE's enigma]. Retrieved from www.schwartzman.org.br\%3E

Schwartzman, S. (2013). Uses and abuses of education assessment in Brazil. Prospects, 43(3), 269-288. https://doi.org/10.1007/s11125-013-9275-9

Silveira, L. S., \& Muniz, J. O. (2008). Variações intra e intermetropolitanas da desigualdade de renda racial [Intra- and inter-metropolitan variations of racial income inequality]. Cadernos Metrópole, 16(31), 265-289. https://doi.org/10.1590/2236-9996.2014-3112

Skidmore, T. E. (1974). Black into White: race and nationality in Brazilian thought. New York: Oxford University Press.

Steele, C. M. (1997). A threat in the air: how stereotypes shape intellectual identity and performance. American Psychologist, 52(6), 613-629.

Strayhorn, T. L. (2006). Factors influencing the academic achievement of first-generation college students. NASPA Journal, 43(4). https://doi.org/10.2202/0027-6014.1724

Strayhorn, T. L., \& Johnson, R. M. (2014). Black Female Community College Students' Satisfaction: A National Regression Analysis. Community College Journal of Research and Practice, 38(6), 534-550. https://doi.org/10.1080/10668926.2013.866060 
Tardy, C. H. (1985). Social support measurement and intervention. American Journal of Community Psychology, 13(2), 187-202.

Tavolaro, L. G. M. (2008). Affirmative action in contemporary Brazil: two institutional discourses on race. International Journal of Politics, Culture, and Society, 19(3-4), 145-160. https://doi.org/10.1007/s10767-008-9022-z

Terribili Filho, A., \& Nery, A. C. B. (2009). Ensino superior noturno no Brasil: históra, atores e políticas [Evening higher education in Brazil: history, actors and policies]. Revista Brasileira de Política e Administração Da Educação, 25(1), 61-81.

Tinto, V. (1975). Dropout from Higher Education : A Theoretical Synthesis of Recent Research Author ( s ): Vincent Tinto Source : Review of Educational Research, Vol . 45 , No . 1 ( Winter , 1975 ), pp . 89-125 Published by : American Educational Research Association Stab. Review, 45(1), 89-125.

Tovar, E. (2014). The Role of Faculty, Counselors, and Support Programs on Latino / a Community College Students ' Success and Intent to Persist. https://doi.org/10.1177/0091552114553788

Valente, R. R., \& Berry, B. J. L. (2017). Performance of students admitted through affirmative action in Brazil. Latin American Research Review. Retrieved from http://larcommons.org/larr

Velloso, J. (2009). Cotistas e não-cotistas: rendimento de alunos da Universidade de Brasília. Cadernos de Pesquisa, 39(137), 621-644. https://doi.org/10.1590/S010015742009000200014

Verhine, R. E., \& Dantas, L. M. V. (2009). A avaliação do desempenho de alunos de educação superior: uma análise a partir da experiência do ENADE. In J. A. Lord, Carvalho \& M. Virgínia Dazzani (Eds.), Desatando e reatando nós (pp. 173-199). Salvador, Bahia. 
Viana, M. J. B. (1998). Longevidade escolar em famílias de camadas populares: algumas condições de possibilidade [School longevity in low income families: some conditions of possibility]. Federal University of Minas Gerais. Retrieved from http://scholar.google.com.br/scholar?hl=pt-

PT\&q=Educação+e+Diversidade + Cultural:+refletindo + sobre + as + diferentes + presen ças + na + escola\&btnG $=\& 1 \mathrm{r}=\# 9$

Waltenberg, F., \& Carvalho, M. (2013). Cotas aumentam a diversidade dos estudantes sem comprometer o desempenho? [Do quotas increase student diversity without compromising performance?]. Center for Studies on Inequality and Development, (Discussion Paper no 73).

Wohlgemuth, D., Whalen, D., Sullivan, J., Nading, C., Mack, S., \& Yongyi, W. (2006). Financial, academic, and environmental influences on the retention and graduation of students. Journal of College Student Retention, 8(4), 457-475. https://doi.org/10.2190/86X6-5VH8-3007-6918

Xavier, S. (2014). Vestibular e Enem : um debate contemporâneo, 1057-1090.

Zago, N. (2000). Quando os dados contrariam as previsões estatísticas: os casos de êxito escolar nas camadas socialmente desfavorecidas [ When the data contradict the statistical forecasts: the cases of school success in the socially disadvantaged strata]. Paidéia (Ribeirão Preto), 10(18), 70-80. https://doi.org/10.1590/S0103$863 \times 2000000100007$ 
VITA

GABRIELA M. GILLESPIE

Born, São Paulo, Brazil

Education and Experience

December 2011 Master of Education, Higher Education and Student Affairs University of South Carolina

May 2009 Bachelor of Science, Business Administration, Marketing

May 2009 Bachelor of Arts, Spanish Literature

Minor: Latin American Studies

University of Florida, Gainesville, FL GPA 3.81/4.0

February 2019 - Present Integration Program Manager

University of Maryland

May 2018 - February 2019 Assistant Director, International Programs

Association of Public and Land-grant Universities

September 2014 - August 2017 Senior Manager, Office of Global Initiatives

Florida International University

May 2013 - September 2014 Academic Advisor, School of Hospitality \& Tourism Florida International University

July 2010 - April 2013 International Student Advisor

University of South Carolina

Publications

Gillespie, G. (2012, March 2). Guide to Advising International Students about Academic Integrity. The Mentor: An Academic Advising Journal. 